\title{
Development and Testing of a Comprehensive Chemical Mechanism for the Oxidation of Methane
}

\author{
K. J. HUGHES ${ }^{1}$
}

Department of Fuel and Energy, University of Leeds, Leeds, LS2 9JT, UK

\section{T. TURÁNYI}

Department of Physical Chemistry, Eötvös University (ELTE), H-1518 Budapest, P.O. Box 32, Hungary, and Chemical Research Center, H-1525 Budapest, P.O. Box 17, Hungary

\section{A. R. CLAGUE, ${ }^{2}$ M. J. PILLING}

School of Chemistry, University of Leeds, Leeds, LS2 9JT, UK

Received 28 May 1999; accepted 3 May 2001

\begin{abstract}
A comprehensive chemical mechanism to describe the oxidation of methane has been developed, consisting of 351 irreversible reactions of 37 species. The mechanism also accounts for the oxidation kinetics of hydrogen, carbon monoxide, ethane, and ethene in flames and homogeneous ignition systems in a wide concentration range. It has been tested against a variety of experimental measurements of laminar flame velocities, laminar flame species profiles, and ignition delay times. The highest sensitivity reactions of the mechanism are discussed in detail and compared with the same reactions in the GRI, Chevalier, and Konnov mechanisms. Similarities and differences of the four mechanisms are discussed. The mechanism is available on the Internet as a fully documented CHEMKIN data file at the address http://www.chem.leeds.ac.uk/Combustion/Combustion.html. (C) 2001 John Wiley \& Sons, Inc. Int J Chem Kinet 33: 513-538, 2001
\end{abstract}

\section{INTRODUCTION}

A full understanding of the oxidation kinetics of simple fuels, like hydrogen, carbon monoxide, ethene,

\footnotetext{
Correspondence to: K. J. Hughes (kevinh@chem.leeds.ac.uk) ${ }^{1}$ Current Address: School of Chemistry, University of Leeds, Leeds LS2 9JT, UK

${ }^{2}$ Current Address: DERA, DERA Pyestock, Farnborough, Hants. GU14 OLS, UK

(C) 2001 John Wiley \& Sons, Inc.
}

ethane, and especially methane is a primary goal in combustion chemistry. To achieve this understanding, a detailed mechanism for the oxidation of methane is required, which will also be applicable to the aforementioned simple fuels. However, it is somewhat surprising that no detailed methane oxidation mechanism has been generally accepted as a reference oxidation mechanism. The mechanisms of Warnatz [1,2] have been used by many people, but were mainly created as illustrations in combustion modeling papers rather 
than as recommended comprehensive reference mechanisms. Another widely used mechanism is the methane component of the Miller-Bowman NO mechanism [3] which, like the Warnatz mechanism, is now outof-date in many respects. A more recent comprehensive mechanism, tested with continuous stirred tank and flow tube data was developed by Barbe et al. [4].

Detailed combustion mechanisms are based on measurements of elementary gas phase reaction rate coefficients. These measurements have provided the temperature and pressure dependencies of the overall rate coefficients and, in some cases, also the branching ratios of product channels, and are now available for many reactions relevant to the oxidation of simple fuels. However, such mechanisms do not accurately describe all of the bulk experimental data, such as laminar flame velocities, laminar flame species profiles, and ignition delay times. In all cases, small adjustments in some rate coefficients are needed to obtain a reaction mechanism that could reasonably predict the experimental data.

Frenklach [5,6] recommended the creation of optimal performance reaction mechanisms by fitting the parameters of some reaction steps to bulk experimental data. This concept was developed further and led to the creation of the GRI mechanism $[7,8]$, currently at version 3.0, which is a methane oxidation mechanism extended with $\mathrm{NO}_{\mathrm{x}}$ chemistry. The GRI mechanism is based on elementary reactions, where a combination of experimental and theoretically determined values are assigned to the rate parameters. The simulation results from the starting mechanism are compared to bulk experimental data consisting of ignition delay times, laminar flame speeds, and species profiles obtained from shock-tube ignition experiments, laminar flames, and flow reactors. An extensive sensitivity test shows, in each case, which parameters need to be tuned to minimize the difference between the experimental data and the simulation results. The parameters are simultaneously optimized automatically by a computer program, but with their values maintained within predefined uncertainty limits. One of the pioneering ideas of the GRI mechanism was that the mechanism, its testing, and related information are available through the Internet [9].

Another combustion mechanism also available through the Internet was developed by Konnov. Like GRI, the mechanism is in CHEMKIN [10] format, and is accompanied by thermodynamic and transport data [11]. Chevalier [12] has revised the earlier Warnatz mechanisms to produce a generally applicable, widely tested mechanism.
Our aim is to create a mechanism fully based on gas kinetics measurements, and, where possible, on evaluated rate parameters, which is fully referenced and annotated. A Web site has been set up that serves simultaneously as a source of information for the best evaluated data available and also as a source for a tested reaction mechanism. Because CHEMKIN [10] is the most widely used software for combustion simulations with detailed chemistry, we have chosen CHEMKIN as the format for the data. The commented mechanism is downloadable from our Web site [13]. This paper reports version 1.4. It is likely that the mechanism will have updated versions as well, but the earlier versions are archived and are available on the same Web site.

A group of European kinetics have evaluated $[14,15]$ the rate coefficients of many elementary reactions relevant to the oxidation of simple fuels. This work will be referred to as the CEC (Commission of European Communities) evaluation. In the CEC evaluation, the rate coefficients are usually provided in a single direction only, but in some cases there are separate recommendations for forward and reverse reactions, and the reverse reaction rate coefficients given this way are usually more accurate than those calculated from the forward rate coefficient and thermodynamic data. Therefore, the mechanism contains both reversible and irreversible reactions. To make the sensitivity investigations unambiguous, a FORTRAN program was written that converts all reversible reactions in a mechanism to pairs of irreversible reactions. This program, called MECHMOD [13], reads the binary CHEMKIN mechanism file and prints out a $\mathrm{CHE}$ MKIN format text mechanism file. Additionally, the program can also be used for a systematic elimination of selected species from the mechanism and the automatic conversion of rate parameters to different units.

Another FORTRAN program mounted on the same web site, KINALC [13], was written for the analysis of CHEMKIN format mechanisms by processing the information contained in CHEMKIN binary output files. KINALC contains almost all methods that have been used for the analysis of reaction mechanisms. In this study, extensive use of the options related to sensitivity analysis were used, including ordered lists of flame velocity sensitivities, temperature sensitivities, and sensitivities of single or several species, calculated from the binary output of programs SENKIN [16] and PREMIX [17]. SENKIN calculates first order sensitivity coefficients, defined as $w_{j, i}=\partial Z_{j} / \partial A_{i}$, where $Z$ is temperature or a species mass fraction, and $A$ represents the pre-exponential constant for the elementary 
reactions. PREMIX calculates normalized first order sensitivity coefficients, defined as $w_{j, i}=\left(A_{i} / Z_{j}\right) \partial Z_{j} / \partial A_{i}$, where $Z$ represents temperature, flame velocity, or species mass fraction.

This paper reports the development of the mechanism, describes the format of accompanying notes, and provides the results of testing against bulk experimental data. Sensitivity was investigated in various systems and rate coefficient expressions for high sensitivity reactions were justified and compared with the similar reactions in the other three mechanisms. The full mechanism is available from our Web site [13]. Table I includes reactions found to have a high sensitivity in the systems investigated, and the reaction numbers given in this paper refer to Table I.

\section{MECHANISM DEVELOPMENT}

The initial starting point for compilation of the mechanism were the papers by Miller and Bowman [3] and Glarborg et al. [18]. Each reaction was then individually checked and its rate data updated where necessary. The CEC evaluation $[14,15]$ was used as the primary source. Other sources were also used for rate data not available from the CEC evaluation, including the NIST chemical kinetics database [19], the Leeds Kinetics Database [20], and the evaluations of Tsang and Hampson [21] and Warnatz [22]. Additionally, the literature was monitored for new information on reactions of interest and the mechanism was adjusted if necessary. To obtain rate coefficients of reversible reactions via the forward reaction and equilibrium constant, the thermodynamic database supplied with the CHEMKIN software was used. No systematic attempt was made to tune the mechanism by alteration of thermodynamic parameters, the only change made being a reduction in the heat of formation of ${ }^{1} \mathrm{CH}_{2}$ by $4 \mathrm{kJmol}^{-1}$ [23]. The CHEMKIN package contains a database for transport parameters. These parameters, required for PREMIX calculations, were used without any modification.

One of the goals of this work is to produce a mechanism whose origins are clear and that is comprehensively documented, therefore, the following additional information is included in the CHEMKIN reaction mechanism text file. Appendix A of the file illustrates these points by showing a section of the final mechanism.

(i) Other possible channels. All other feasible channels are listed here, even if not all of them were included in the mechanism. This infor- mation helps a later revision of multichannel reactions.

(ii) Classification of the rate data. A major problem in all mechanisms is that it is not easy to see at first glance if a particular rate coefficient is well characterized, or if it is only based on an old assumption, with a minimal basis, that has been copied later from mechanism to mechanism. A letter coding has been devised that denotes the origin and reliability of the kinetic data. "A" denotes well-established rate parameters where the evaluation is based on several measurements in good agreement. "B" denotes evaluated rate parameters where the evaluation is based on few or conflicting measurements. Data, based on measurements and taken from the CEC evaluation [14,15], Tsang and Hampson [21], or Warnatz [22] were denoted by either "A" or "B." The assignation was based on the text of the evaluations and is somewhat subjective. Some elementary reactions have not been evaluated, but they have been the subject of experimental studies to determine their rate coefficients. Letters " $C$ " to "F" denote these reactions, which correspond to different types of experiment. "C" denotes a low temperature indirect measurement, usually from studies based on GC end product analysis, "D" designates low-temperature direct measurements as in laser flash photolysis experiments with direct monitoring of species. "E" is used for high temperature indirect measurements, based, for example, on a shocktube or flow reactor, while " $F$ " designates high-temperature direct measurements, usually with shock-tube excitation and direct optical monitoring of one or more of the reactants or products. In this classification, high-temperature measurements are defined as those over $1100 \mathrm{~K}$. In some cases, no experimental data were available, but there has been a detailed theoretical investigation of the reaction; "T" denotes these reactions. In other cases, denoted by "S," experimental data or detailed theoretical calculations were not available, but a reasonable estimation has been made on the basis of data for analogous reactions. Finally, for the rest of the reactions, no experimental data, no theoretical calculation, and no basis for a good estimation were available. These uncertain reactions are denoted by "U." Multichannel reactions represent a special problem, because in many cases 
Table I The Most Sensitive Reactions in Our Mechanism and Their Rate Coefficients

\begin{tabular}{|c|c|c|c|c|c|c|}
\hline & Reaction & $A$ & $n$ & $E_{a} / \mathrm{kJmol}^{-1}$ & Category & Reference \\
\hline $\mathrm{R} 1$ & $\mathrm{H}_{2}+\mathrm{OH} \longrightarrow \mathrm{H}_{2} \mathrm{O}+\mathrm{H}$ & $1.02 \times 10^{8}$ & 1.6 & 13.8 & A & 15 \\
\hline $\mathrm{R} 2$ & $\mathrm{O}_{2}+\mathrm{H} \longrightarrow \mathrm{OH}+\mathrm{O}$ & $9.76 \times 10^{13}$ & 0 & 62.11 & A & 15 \\
\hline $\mathrm{R} 3$ & $\mathrm{H}_{2}+\mathrm{O} \longrightarrow \mathrm{OH}+\mathrm{H}$ & $5.12 \times 10^{4}$ & 2.67 & 26.27 & A & 15 \\
\hline $\mathrm{R} 4$ & $\mathrm{OH}+\mathrm{O} \longrightarrow \mathrm{O}_{2}+\mathrm{H}$ & $1.45 \times 10^{13}$ & 0 & 2.94 & $\mathrm{~A}$ & 15 \\
\hline R5 & $\mathrm{H}+\mathrm{HO}_{2} \longrightarrow 2 \mathrm{OH}$ & $1.69 \times 10^{14}$ & 0 & 3.66 & A & 15 \\
\hline R6 & $\mathrm{O}_{2}+\mathrm{H}+\mathrm{M} \longrightarrow \mathrm{HO}_{2}+\mathrm{M}$ & $2.10 \times 10^{18}$ & -0.8 & 0.0 & $\mathrm{~B}$ & 15 \\
\hline R7 & $\mathrm{H}+\mathrm{HO}_{2} \longrightarrow \mathrm{H}_{2}+\mathrm{O}_{2}$ & $4.28 \times 10^{13}$ & 0 & 5.9 & $\mathrm{~A}$ & 15 \\
\hline R8 & $\mathrm{CO}+\mathrm{OH} \longrightarrow \mathrm{CO}_{2}+\mathrm{H}$ & $1.66 \times 10^{7}$ & -1.3 & -3.2 & A & $32^{1}$ \\
\hline R9 & $\mathrm{O}+\mathrm{H}_{2} \mathrm{O} \longrightarrow 2 \mathrm{OH}$ & $1.49 \times 10^{11}$ & 0.87 & 74.56 & A & 15 \\
\hline $\mathrm{R} 10$ & $2 \mathrm{OH} \longrightarrow \mathrm{O}+\mathrm{H}_{2} \mathrm{O}$ & $1.51 \times 10^{9}$ & 1.14 & 0.42 & A & 15 \\
\hline $\mathrm{R} 11$ & $\mathrm{CO}_{2}+\mathrm{H} \longrightarrow \mathrm{CO}+\mathrm{OH}$ & $8.70 \times 10^{13}$ & 0.01 & 105.97 & A & 15 \\
\hline $\mathrm{R} 12$ & $\mathrm{H}+\mathrm{CO}+\mathrm{M} \longrightarrow \mathrm{HCO}+\mathrm{M}$ & $5.49 \times 10^{14}$ & 0 & 3.08 & $\mathrm{~A}$ & 15 \\
\hline $\mathrm{R} 13$ & $\mathrm{H}+\mathrm{HCO} \longrightarrow \mathrm{H}_{2}+\mathrm{CO}$ & $9.03 \times 10^{13}$ & 0 & 0.0 & A & 15 \\
\hline $\mathrm{R} 14$ & $\mathrm{HCO}+\mathrm{M} \longrightarrow \mathrm{H}+\mathrm{CO}+\mathrm{M}$ & $4.49 \times 10^{14}$ & 0 & 65.93 & A & 15 \\
\hline $\mathrm{R} 15$ & $\mathrm{CH}_{3}+\mathrm{OH} \longrightarrow{ }^{1} \mathrm{CH}_{2}+\mathrm{H}_{2} \mathrm{O}$ & $7.23 \times 10^{13}$ & 0.0 & 11.64 & $\mathrm{~B}$ & $15^{2}$ \\
\hline \multirow[t]{2}{*}{ R16 } & $\mathrm{H}+\mathrm{CH}_{3}+\mathrm{M} \longrightarrow \mathrm{CH}_{4}+\mathrm{M}$ & $1.69 \times 10^{14}$ & 0 & 0.0 & $\mathrm{~B}$ & $15^{3}$ \\
\hline & Reaction 16 , low pressure: & $1.41 \times 10^{24}$ & -1.8 & 0.0 & $\mathrm{~B}$ & \\
\hline \multirow[t]{2}{*}{ R17 } & $2 \mathrm{CH}_{3}+\mathrm{M} \longrightarrow \mathrm{C}_{2} \mathrm{H}_{6}+\mathrm{M}$ & $3.61 \times 10^{13}$ & 0 & 0.0 & $\mathrm{~A}$ & 15 \\
\hline & Reaction 17 , low pressure: & $3.63 \times 10^{241}$ & -7.0 & 11.56 & A & \\
\hline $\mathrm{R} 18$ & $\mathrm{CH}_{3}+\mathrm{O} \longrightarrow \mathrm{CH}_{2} \mathrm{O}+\mathrm{H}$ & $8.43 \times 10^{13}$ & 0 & 0.0 & A & 15 \\
\hline $\mathrm{R} 19$ & $\mathrm{CH}_{4}+\mathrm{H} \longrightarrow \mathrm{CH}_{3}+\mathrm{H}_{2}$ & $1.32 \times 10^{4}$ & 3.0 & 33.63 & A & 15 \\
\hline R20 & $\mathrm{CH}_{3}+\mathrm{H}_{2} \longrightarrow \mathrm{CH}_{4}+\mathrm{H}$ & $6.87 \times 10^{3}$ & 2.74 & 39.41 & A & 15 \\
\hline $\mathrm{R} 21$ & $2 \mathrm{CH}_{3}+\mathrm{M} \longrightarrow \mathrm{C}_{2} \mathrm{H}_{5}+\mathrm{H}+\mathrm{M}$ & $3.01 \times 10^{13}$ & 0 & 56.54 & $\mathrm{~B}$ & 15 \\
\hline \multirow[t]{2}{*}{$\mathrm{R} 22$} & $\mathrm{CH}_{4}+\mathrm{M} \longrightarrow \mathrm{CH}_{3}+\mathrm{H}+\mathrm{M}$ & $2.40 \times 10^{16}$ & 0 & 439.01 & $\mathrm{~B}$ & 15 \\
\hline & Reaction 22 , low pressure: & $1.29 \times 10^{18}$ & 0 & 379.97 & & \\
\hline $\mathrm{R} 23$ & $\mathrm{O}_{2}+\mathrm{CH}_{3} \longrightarrow \mathrm{CH}_{3} \mathrm{O}+\mathrm{O}$ & $4.40 \times 10^{13}$ & 0 & 131.37 & $\mathrm{~B}$ & $15^{4}$ \\
\hline $\mathrm{R} 24$ & $\mathrm{CH}_{4}+\mathrm{O} \longrightarrow \mathrm{CH}_{3}+\mathrm{OH}$ & $7.23 \times 10^{8}$ & 1.56 & 35.50 & $\mathrm{~A}$ & 15 \\
\hline $\mathrm{R} 25$ & $\mathrm{O}_{2}+\mathrm{CH}_{3} \longrightarrow \mathrm{CH}_{2} \mathrm{O}+\mathrm{OH}$ & $3.31 \times 10^{11}$ & 0 & 37.42 & $\mathrm{~B}$ & 15 \\
\hline $\mathrm{R} 26$ & $\mathrm{CH}_{4}+\mathrm{OH} \longrightarrow \mathrm{CH}_{3}+\mathrm{H}_{2} \mathrm{O}$ & $1.57 \times 10^{7}$ & 1.83 & 11.64 & A & 15 \\
\hline $\mathrm{R} 27$ & $\mathrm{CH}_{3}+\mathrm{HO}_{2} \longrightarrow \mathrm{CH}_{3} \mathrm{O}+\mathrm{OH}$ & $1.80 \times 10^{13}$ & 0 & 0 & $\mathrm{~B}$ & 15 \\
\hline $\mathrm{R} 28$ & $\mathrm{CH}_{2} \mathrm{O}+\mathrm{OH} \longrightarrow \mathrm{HCO}+\mathrm{H}_{2} \mathrm{O}$ & $3.43 \times 10^{9}$ & 1.18 & -1.87 & A & 15 \\
\hline $\mathrm{R} 29$ & $\mathrm{CH}_{2} \mathrm{O}+\mathrm{CH}_{3} \longrightarrow \mathrm{CH}_{4}+\mathrm{HCO}$ & $7.83 \times 10^{-8}$ & 6.1 & 8.23 & A & 15 \\
\hline \multirow[t]{2}{*}{ R30 } & $\mathrm{C}_{2} \mathrm{H}_{6}+\mathrm{M} \longrightarrow 2 \mathrm{CH}_{3}+\mathrm{M}$ & $1.80 \times 10^{21}$ & -1.24 & 379.97 & $\mathrm{~A}$ & 15 \\
\hline & Reaction 30 , low pressure: & $1.89 \times 10^{49}$ & -8.24 & 391.53 & & \\
\hline $\mathrm{R} 31$ & $\mathrm{C}_{2} \mathrm{H}_{4}+\mathrm{O} \longrightarrow \mathrm{H}+\mathrm{CH}_{2} \mathrm{HCO}$ & $4.74 \times 10^{6}$ & 1.88 & 0.75 & $\mathrm{~A} / \mathrm{B}$ & 15 \\
\hline $\mathrm{R} 32$ & $\mathrm{C}_{2} \mathrm{H}_{4}+\mathrm{O} \longrightarrow \mathrm{CH}_{3}+\mathrm{HCO}$ & $8.13 \times 10^{6}$ & 1.88 & 0.75 & $\mathrm{~A} / \mathrm{B}$ & 15 \\
\hline R33 & $\mathrm{C}_{2} \mathrm{H}_{4}+\mathrm{OH} \longrightarrow \mathrm{C}_{2} \mathrm{H}_{3}+\mathrm{H}_{2} \mathrm{O}$ & $2.05 \times 10^{13}$ & 0 & 24.86 & $\mathrm{~B}$ & 15 \\
\hline $\mathrm{R} 34$ & $\mathrm{C}_{2} \mathrm{H}_{2}+\mathrm{O} \longrightarrow{ }^{3} \mathrm{CH}_{2}+\mathrm{CO}$ & $2.17 \times 10^{6}$ & 2.1 & 6.57 & $\mathrm{~A} / \mathrm{A}$ & 15 \\
\hline $\mathrm{R} 35$ & $\mathrm{C}_{2} \mathrm{H}_{2}+\mathrm{O} \longrightarrow \mathrm{HCCO}+\mathrm{H}$ & $5.06 \times 10^{6}$ & 2.1 & 6.57 & $\mathrm{~A} / \mathrm{A}$ & 15 \\
\hline $\mathrm{R} 36$ & $\mathrm{CH}_{2} \mathrm{CO}+\mathrm{H} \longrightarrow \mathrm{CH}_{3}+\mathrm{CO}$ & $1.81 \times 10^{13}$ & 0 & 14.13 & $\mathrm{~B} / \mathrm{U}$ & 15 \\
\hline R37 & $\mathrm{C}_{2} \mathrm{H}_{4}+\mathrm{H} \longrightarrow \mathrm{C}_{2} \mathrm{H}_{3}+\mathrm{H}_{2}$ & $5.42 \times 10^{14}$ & 0 & 62.36 & A & 15 \\
\hline $\mathrm{R} 38$ & $\mathrm{C}_{2} \mathrm{H}_{6}+\mathrm{H} \longrightarrow \mathrm{C}_{2} \mathrm{H}_{5}+\mathrm{H}_{2}$ & $1.45 \times 10^{9}$ & 1.5 & 31.01 & A & 15 \\
\hline R39 & $\mathrm{OH}+\mathrm{HO}_{2} \longrightarrow \mathrm{H}_{2} \mathrm{O}+\mathrm{O}_{2}$ & $2.89 \times 10^{13}$ & 0 & -2.08 & $\mathrm{~A}$ & 15 \\
\hline \multirow[t]{2}{*}{$\mathrm{R} 40$} & $\mathrm{C}_{2} \mathrm{H}_{3}+\mathrm{M} \longrightarrow \mathrm{C}_{2} \mathrm{H}_{2}+\mathrm{H}+\mathrm{M}$ & $2.00 \times 10^{14}$ & 0 & 166.29 & $\mathrm{~B}$ & 15 \\
\hline & Reaction 40 , low pressure: & $1.19 \times 10^{42}$ & -7.5 & 190.4 & $\mathrm{~B}$ & \\
\hline $\mathrm{R} 41$ & $\mathrm{OH}+\mathrm{H} \longrightarrow \mathrm{H}_{2}+\mathrm{O}$ & $3.53 \times 10^{4}$ & 2.62 & 18.95 & A & 15 \\
\hline $\mathrm{R} 42$ & $\mathrm{H}_{2}+\mathrm{H} \longrightarrow \mathrm{H}_{2}+\mathrm{OH}$ & $4.52 \times 10^{8}$ & 1.6 & 77.08 & A & 15 \\
\hline $\mathrm{R} 43$ & $\mathrm{CH}_{3}+\mathrm{HCO} \longrightarrow \mathrm{CH}_{4}+\mathrm{CO}$ & $1.20 \times 10^{14}$ & 0 & 0 & $\mathrm{~B}$ & 21 \\
\hline $\mathrm{R} 44$ & $\mathrm{H}+{ }^{3} \mathrm{CH}_{2} \longrightarrow \mathrm{CH}+\mathrm{H}_{2}$ & $6.02 \times 10^{12}$ & 0 & -7.48 & $\mathrm{~B}$ & 15 \\
\hline
\end{tabular}

1, Increased by $10 \%$ above reference value; 2 , Corrected a factor of ten error in the CEC evaluation summary page; 3 , Modified to $80 \%$ of the CEC recommendation; 4, Reduced by a factor of three from the CEC evaluation. 
there is much information on the overall rate coefficient, but very little on the product channels and especially on the temperature dependence of the branching ratios. For multichannel reactions a double classification of the form "X/Y" was used; " $\mathrm{X}$ " represents the overall reaction, " $\mathrm{Y}$ " represents the product channels. As an example, "A/U” denotes wellcharacterized overall reaction rate parameters with uncertain product channel ratios. We believe that the above letter coding provides an instant assessment of the quality of a given rate coefficient without having to resort to a laborious search of the literature.

(iii) Uncertainties. While the previous letter coding provides a qualitative assessment of the reliability of the data, reaction uncertainties are also given a numerical form. In agreement with the CEC evaluation $[14,15]$, the uncertainty is expressed as $\Delta \log k$, which corresponds to the statement that $k$ is uncertain by a factor $F$, where $\log F=\Delta \log k$. Warnatz [22] and Tsang and Hampson [21] also used this uncertainty definition. Most of the uncertainties were taken from these evaluations. In cases "C"-"U," evaluated data were not available, and the uncertainties were estimated.

(iv) Temperature intervals. In most cases there is information about the reaction only over a restricted temperature range, and stating a low uncertainty would be misleading if the mechanism is used at different, usually higher, temperatures. The uncertainty information is, therefore, amended with a temperature interval. The indicated temperature interval corresponds to that of the evaluation ("A," "B"), the temperature interval of the measurement ("C" - "F"), and the temperature interval of assumed validity ("T," "S," and "U").

(v) Reference. The referencing follows the style of the NIST database [19], even though some of the cited papers are not included there. This format provides immediate clear information about the age of the data and the authors of the source.

In the final step, the reactions of the annotated mechanism were rearranged. First, an order of species was defined, based on (I) hydrocarbon molecules, (II) $\mathrm{H} / \mathrm{C} / \mathrm{O}$ molecules, (III) hydrocarbon radicals, (IV) $\mathrm{H} / \mathrm{C} / \mathrm{O}$ radicals, and (V) buffer gases, with each class ordered in terms of increasing complexity. The reactions were then rearranged in such a way that all reactions of the first species in the ordered list come first, then all reactions of the second species, etc. This ordering facilitates rapid searching for a given reaction within the mechanisms.

In some reaction mechanisms, species are all denoted by an overall formula and the structures of the species are not defined. As a result, mixed reactions of molecules with different structures are represented. To avoid this problem, the structure of each species has also been defined where necessary. The structure is obvious for most species, with the following exceptions: Formula $\mathrm{C}_{3} \mathrm{H}_{4}$ denotes both structures $\mathrm{CH}_{3}-\mathrm{CCH}$ and $\mathrm{CH}_{2}=\mathrm{C}=\mathrm{CH}_{2}$. Also, $\mathrm{CH}_{2} \mathrm{HCO}$ denotes both $\cdot \mathrm{CH}_{2} \mathrm{COH}$ and $\mathrm{CH}_{2}=\mathrm{CH}-\mathrm{O} \cdot$. Formulae $\mathrm{C}_{4} \mathrm{H}_{2}, \mathrm{CH}_{2} \mathrm{CO}, \mathrm{C}_{3} \mathrm{H}_{2}$, and HCCO identify structures $\mathrm{HCC}-\mathrm{CCH}, \quad \mathrm{H}_{2} \mathrm{C}=\mathrm{C}=\mathrm{O}, \quad \mathrm{CH}-\mathrm{CC}-\mathrm{H}$, and $\mathrm{H} \cdot \mathrm{C}=\mathrm{C}=\mathrm{O}$, respectively. Even recently, the structures of $\mathrm{H}_{2} \mathrm{CCCH}$ and $\mathrm{H}_{2} \mathrm{CCCCH}$ have been debated; these were identified as the propargyl radical $\left(\cdot \mathrm{CH}_{2} \mathrm{CCH} \leftrightarrow \mathrm{CH}_{2}=\mathrm{C}=\mathrm{CH} \cdot\right)$ and butenyn-2-yl $\left(\mathrm{CH}_{2}=\mathrm{C} \cdot-\mathrm{CC}-\mathrm{H}\right)$, respectively [24,25].

Any reaction mechanism would extend indefinitely if the reactions of all reaction products were fully taken into account. In the Leeds mechanism some reaction channels are neglected. These reaction products are minor species, which have little influence on the concentration of species considered important. The following species were not included in this mechanism: $\mathrm{CH}_{3} \mathrm{OH}$ (product of reaction $\mathrm{CH}_{3}+\mathrm{OH}+$ $\mathrm{M}$ ), $\mathrm{CH}_{3} \mathrm{CHO}$ (product of $\mathrm{CH}_{2} \mathrm{H}_{5}+\mathrm{O}$ ), $\mathrm{C}_{2} \mathrm{O}$ (product of reactions $\mathrm{HCCO}+\mathrm{O}_{2}, \mathrm{CO}+\mathrm{CH}$, and $\mathrm{CO}_{2}+$ $\mathrm{CH}$ ), and $\mathrm{C}_{3} \mathrm{H}_{2} \mathrm{O}$ (from reaction $\mathrm{H}_{2} \mathrm{CCCH}+\mathrm{O}$ ). In place of these reactions, alternative product channels were used.

Following Warnatz [22], in most third body reactions the concentrations were weighted as follows: $\mathrm{N}_{2}=0.4, \mathrm{O}_{2}=0.4, \mathrm{CO}=0.75, \mathrm{CO}_{2}=1.5, \mathrm{H}_{2} \mathrm{O}=$ $6.5, \mathrm{C}_{2} \mathrm{H}_{6}=3.0, \mathrm{Ar}=0.35, \mathrm{He}=0.35$. Methane had a weight of 6.5 in the original recommendation of Warnatz [22], but this high value, equivalent to that of water, was reduced to 3.0 in accordance with Grotheer et al. [26]. The weight of all other species is assumed to be one.

Experimental or evaluated low pressure limiting rate coefficients have been reported for bath gases nitrogen, helium, argon, and ethane. These cases are indicated in the text. The low pressure " $A$ " factors for these reactions were scaled to a general collider with unit weight according to the prior weighting. Helium does not appear as a separate species in the mechanism; the third body efficiency given previously was used for scaling the experimental data reported with helium as bath gas. In the few cases where the nitrogen 
and argon data scaled back to a unit collision efficiency differ, the nitrogen data have been chosen.

\section{SIMULATION OF EXPERIMENTAL DATA}

A selection of experimental data was chosen for test simulations, consisting of laminar flame speeds and ignition delay times for a range of different fuels. The majority of these data are those used in the validation of the GRI mechanism [9]. The following sections outline the results of these simulations.

\section{Hydrogen/Air Laminar Flame Speed}

Freely propagating premixed hydrogen/air flames at atmospheric pressure $[27,28,29,30]$ were simulated as a function of equivalence ratio between 0.4 and 6.0. Figure 1 shows the comparison of the computed results with selected experimental measurements. Good agreement is obtained with the experimental results without the need to modify any of the reaction rate coefficients. Figures $2 a-2 c$ show sensitivities with respect to the flame velocity at the extremes of equiva-

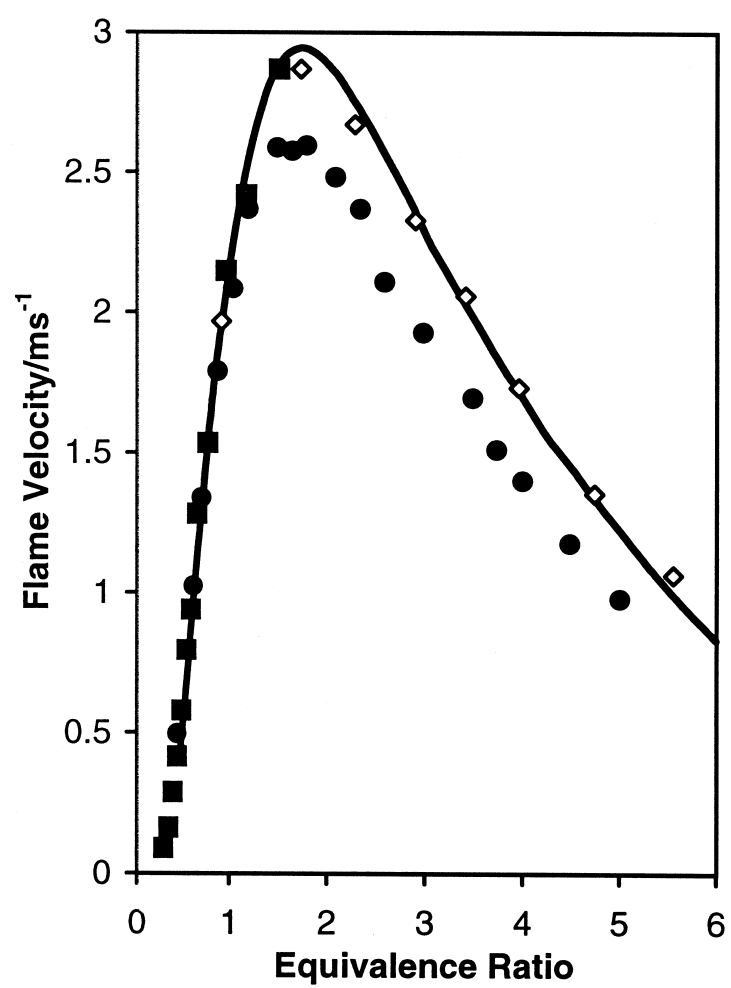

Figure 1 Flame velocity as a function of equivalence ratio for a hydrogen/air mixture. $\mathbf{\square}$, Law et al. [27,28]; $\diamond$, Dowdy et al. [29];, Aung et al. [30]. (a)

$$
\begin{array}{r}
\mathrm{H}_{2}+\mathrm{OH} \rightarrow \mathrm{H}_{2} \mathrm{O}+\mathrm{H} \\
\mathrm{O}_{2}+\mathrm{H} \rightarrow \mathrm{OH}+\mathrm{O} \\
\mathrm{H}_{2}+\mathrm{O} \rightarrow \mathrm{OH}+\mathrm{H} \\
\mathrm{OH}+\mathrm{O} \rightarrow \mathrm{O}_{2}+\mathrm{H} \\
\mathrm{H}+\mathrm{HO}_{2} \rightarrow 2 \mathrm{OH} \\
\mathrm{O}_{2}+\mathrm{H}+\mathrm{M} \rightarrow \mathrm{HO}_{2}+\mathrm{M} \\
\mathrm{O}_{2}+\mathrm{H}+\mathrm{H}_{2} \mathrm{O} \rightarrow \mathrm{HO}_{2}+\mathrm{H}_{2} \mathrm{O} \\
\mathrm{H}+\mathrm{HO}_{2} \rightarrow \mathrm{H}_{2}+\mathrm{O}_{2} \\
\mathrm{OH}+\mathrm{HO}_{2} \rightarrow \mathrm{H}_{2} \mathrm{O}+\mathrm{O}_{2} \\
2 \mathrm{OH}(+\mathrm{M}) \rightarrow \mathrm{H}_{2} \mathrm{O}_{2}(+\mathrm{M})
\end{array}
$$

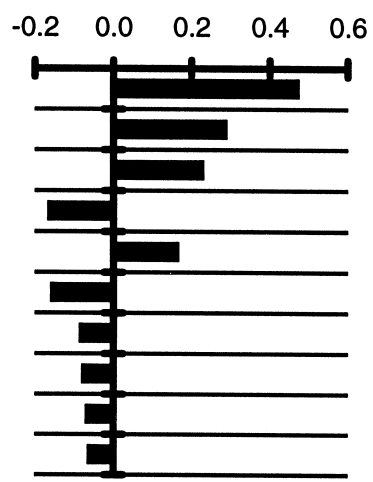

(b)

$$
\begin{array}{r}
\mathrm{O}_{2}+\mathrm{H} \rightarrow \mathrm{OH}+\mathrm{O} \\
\mathrm{H}_{2}+\mathrm{OH} \rightarrow \mathrm{H}_{2} \mathrm{O}+\mathrm{H} \\
\mathrm{H}_{2}+\mathrm{O} \rightarrow \mathrm{OH}+\mathrm{H} \\
\mathrm{H}+\mathrm{HO}_{2} \rightarrow 2 \mathrm{OH} \\
\mathrm{H}+\mathrm{HO}_{2} \rightarrow \mathrm{H}_{2}+\mathrm{O}_{2} \\
\mathrm{H}_{2} \mathrm{O}+\mathrm{H} \rightarrow \mathrm{H}_{2}+\mathrm{OH} \\
\mathrm{H}+\mathrm{OH}+\mathrm{M} \rightarrow \mathrm{H}_{2} \mathrm{O}+\mathrm{M} \\
\mathrm{OH}+\mathrm{O} \rightarrow \mathrm{O}_{2}+\mathrm{H} \\
2 \mathrm{H}+\mathrm{M} \rightarrow \mathrm{H}_{2}+\mathrm{M} \\
\mathrm{O}_{2}+\mathrm{H}+\mathrm{M} \rightarrow \mathrm{HO}_{2}+\mathrm{M}
\end{array}
$$

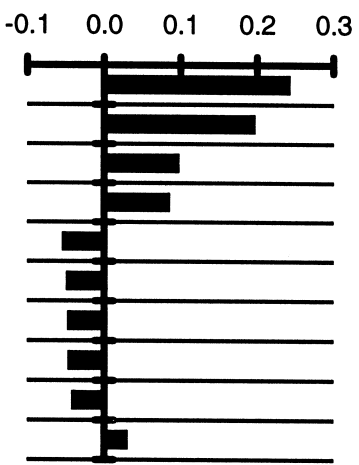

(c)

$$
\begin{array}{r}
\mathrm{O}_{2}+\mathrm{H} \rightarrow \mathrm{OH}+\mathrm{O} \\
\mathrm{H}+\mathrm{HO}_{2} \rightarrow 2 \mathrm{OH} \\
\mathrm{H}+\mathrm{HO}_{2} \rightarrow \mathrm{H}_{2}+\mathrm{O}_{2} \\
2 \mathrm{H}+\mathrm{M} \rightarrow \mathrm{H}_{2}+\mathrm{M} \\
\mathrm{H}_{2}+\mathrm{OH} \rightarrow \mathrm{H}_{2} \mathrm{O}+\mathrm{H} \\
2 \mathrm{H}+\mathrm{H}_{2} \rightarrow 2 \mathrm{H}_{2} \\
\mathrm{O}_{2}+\mathrm{H}+\mathrm{M} \rightarrow \mathrm{HO}_{2}+\mathrm{M} \\
\mathrm{OH}+\mathrm{HO}_{2} \rightarrow \mathrm{H}_{2} \mathrm{O}+\mathrm{O}_{2} \\
\mathrm{H}+\mathrm{OH}+\mathrm{M} \rightarrow \mathrm{H}_{2} \mathrm{O}+\mathrm{M} \\
\mathrm{H}+\mathrm{O} \rightarrow \mathrm{OH}+\mathrm{H}
\end{array}
$$

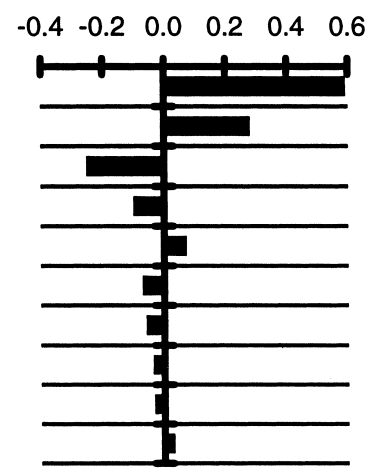

Figure 2 (a) Sensitivity with respect to flame velocity in a hydrogen/air flame, equivalence ratio $=0.4$; (b) Sensitivity with respect to flame velocity in a hydrogen/air flame, equivalence ratio $=1.8$; (c) Sensitivity with respect to flame velocity in a hydrogen/air flame, equivalence ratio $=$ 6.0 .

lence ratio and near the point of maximum flame velocity.

\section{Hydrogen/Oxygen Ignition}

Figure 3 shows the comparison between experiment [31] and simulation for the ignition delay time in a $1 \%$ hydrogen/1\% oxygen/98\% argon mixture between 178 and 288 Torr. In this case, "ignition delay" is a some- 


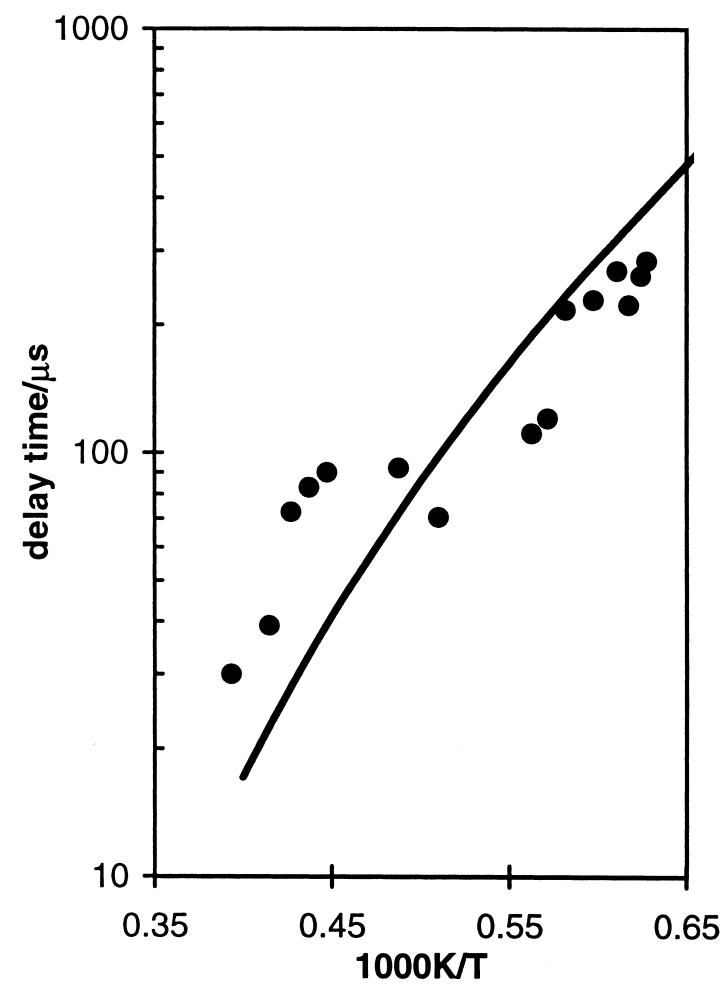

Figure $31 \% \mathrm{H}_{2} / 1 \% \mathrm{O}_{2} / 98 \% \mathrm{Ar}$, time required for $\mathrm{OH}$ to reach $1 \times 10^{8}$. Asaba et al. [31].

what misleading term, as there is no meaningful temperature rise given the dilution of the mixture, and the delay time was defined by the concentration of $\mathrm{OH}$ reaching $1 \times 10^{-8} \mathrm{~mol} \mathrm{dm}^{-3}$. No changes were required for any of the reaction rate coefficients for reactions involving hydrogen or oxygen-based species to achieve the level of agreement shown.

\section{Carbon Monoxide/Hydrogen/Air Laminar Flame Speed}

The comparison between experimental measurements [32] and simulation of the laminar flame speed in a $95 \% \mathrm{CO} / 5 \% \mathrm{H}_{2}$ /air flame at atmospheric pressure is shown in Fig. 4. Figures 5a, 5b, and 5c show sensitivities with respect to flame speed at equivalence ratios of $1.0,2.5$, and 5.0, respectively. The initial value of the rate coefficient for reaction (8), $\mathrm{CO}+\mathrm{OH} \rightarrow$ $\mathrm{CO}_{2}+\mathrm{H}$, in our mechanism was based on the review of Baulch et al. [33]. This choice was made in preference to the higher value recommended in the CEC evaluation $[14,15]$ as a result of the work of McLean et al. [32] who, in simulating these data, find that it is extremely sensitive to the rate coefficient of reaction
(8) in a narrow temperature range around $1165 \mathrm{~K}$, and is inconsistent with the use of the CEC evaluation for this reaction. In our simulations, we observed the same high sensitivity to reaction (8) as can be seen, for example, in Fig. 5b. However, in order to fine tune our simulation, we found that a $10 \%$ increase in the rate coefficient of reaction (8) was necessary. To achieve the same effect by adjusting the rate of any other reaction would have required a larger percentage change in reaction rate parameters for other reactions that are considered to be well-known. These changes would also adversely affect the simulations of the hydrogen/ air laminar flame speed and the hydrogen/oxygen/argon ignition delay time.

\section{Carbon Monoxide/Hydrogen/Oxygen/Argon Ignition Delay}

Figure 6 shows the comparison between experiment and simulation of the product of initial oxygen concentration and ignition delay time vs. temperature in a $3 \%$ carbon monoxide $1 \%$ hydrogen $/ 5 \%$ oxygen $/ 91 \%$ argon mixture at 114 Torr [34]. As was the case in the hydrogen/oxygen ignition system, the ignition delay

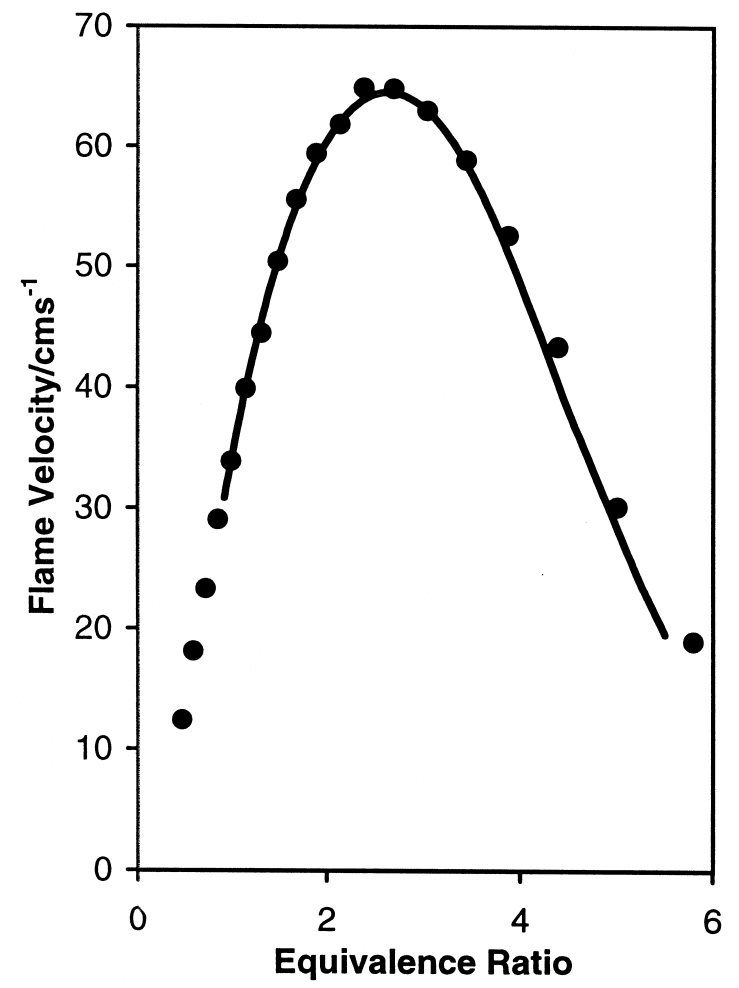

Figure 4 Flame velocity as a function of equivalence ratio for a $95 \% \mathrm{CO} / 5 \% \mathrm{H}_{2} /$ air mixture at 1 atm and $T_{u}=$ 298 K. ๑, McClean et al. [32]. 
(a)

$$
\begin{array}{r}
\mathrm{CO}+\mathrm{OH} \rightarrow \mathrm{CO}_{2}+\mathrm{H} \\
\mathrm{O}_{2}+\mathrm{H} \rightarrow \mathrm{OH}+\mathrm{O} \\
\mathrm{OH}+\mathrm{O} \rightarrow \mathrm{O}_{2}+\mathrm{H} \\
\mathrm{O}_{2}+\mathrm{H}+\mathrm{M} \rightarrow \mathrm{HO}_{2}+\mathrm{M} \\
\mathrm{O}+\mathrm{H}_{2} \mathrm{O} \rightarrow 2 \mathrm{OH} \\
2 \mathrm{OH} \rightarrow \mathrm{O}+\mathrm{H}_{2} \mathrm{O} \\
\mathrm{CO}_{2}+\mathrm{H} \rightarrow \mathrm{CO}+\mathrm{OH} \\
\mathrm{H}+\mathrm{HO}_{2} \rightarrow 2 \mathrm{OH} \\
\mathrm{H}_{2}+\mathrm{O} \rightarrow \mathrm{OH}+\mathrm{H} \\
\mathrm{OH}+\mathrm{HO}_{2} \rightarrow \mathrm{H}_{2} \mathrm{O}+\mathrm{O}_{2}
\end{array}
$$

(b)

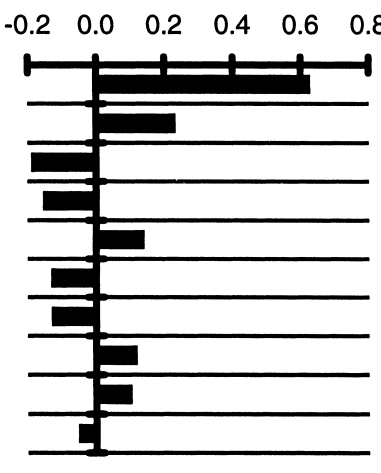

$$
\begin{aligned}
\mathrm{CO}+\mathrm{OH} \rightarrow \mathrm{CO}_{2}+\mathrm{H} \\
\mathrm{O}_{2}+\mathrm{H} \rightarrow \mathrm{OH}+\mathrm{O} \\
\mathrm{H}_{2}+\mathrm{O} \rightarrow \mathrm{OH}+\mathrm{H} \\
\mathrm{H}+\mathrm{HO}_{2} \rightarrow 2 \mathrm{OH} \\
\mathrm{OH}+\mathrm{O} \rightarrow \mathrm{O}_{2}+\mathrm{H} \\
\mathrm{CO}_{2}+\mathrm{H} \rightarrow \mathrm{CO}+\mathrm{OH} \\
\mathrm{H}+\mathrm{CO}+\mathrm{M} \rightarrow \mathrm{HCO}+\mathrm{M} \\
\mathrm{H}_{2}+\mathrm{OH} \rightarrow \mathrm{H}_{2} \mathrm{O}+\mathrm{H} \\
\mathrm{O}_{2}+\mathrm{H}+\mathrm{M} \rightarrow \mathrm{HO}_{2}+\mathrm{M} \\
\mathrm{O}+\mathrm{H}_{2} \mathrm{O} \rightarrow 2 \mathrm{OH}
\end{aligned}
$$

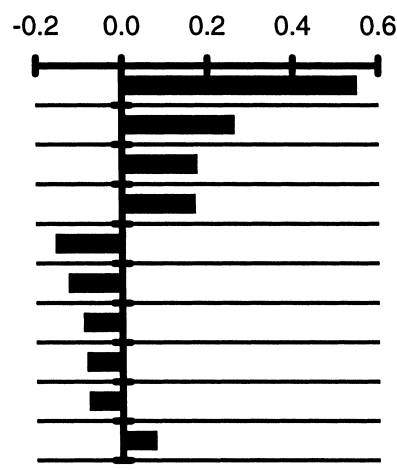

(c)

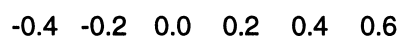

$$
\begin{array}{r}
\mathrm{O}_{2}+\mathrm{H} \rightarrow \mathrm{OH}+\mathrm{O} \\
\mathrm{H}+\mathrm{CO}+\mathrm{M} \rightarrow \mathrm{HCO}+\mathrm{M} \\
\mathrm{CO}+\mathrm{OH} \rightarrow \mathrm{CO}_{2}+\mathrm{H} \\
\mathrm{H}+\mathrm{HO}_{2} \rightarrow 2 \mathrm{OH} \\
\mathrm{H}+\mathrm{HCO} \rightarrow \mathrm{CO}+\mathrm{H}_{2} \\
\mathrm{HCO}+\mathrm{M} \rightarrow \mathrm{H}+\mathrm{CO}+\mathrm{M} \\
\mathrm{H}_{2}+\mathrm{O} \rightarrow \mathrm{OH}+\mathrm{H} \\
\mathrm{H}+\mathrm{HO}_{2} \rightarrow \mathrm{H}_{2}+\mathrm{O}_{2} \\
\mathrm{H}_{2}+\mathrm{OH} \rightarrow \mathrm{H}_{2} \mathrm{O}+\mathrm{H} \\
\mathrm{CO}+\mathrm{O}+\mathrm{M} \rightarrow \mathrm{CO}_{2}+\mathrm{M}
\end{array}
$$

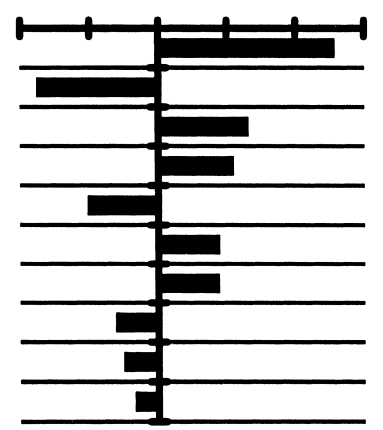

Figure 5 (a) Sensitivity with respect to flame velocity in a $95 \% \mathrm{CO} / 5 \% \mathrm{H}_{2} /$ air flame, equivalence ratio $=1.0$; (b) Sensitivity with respect to flame velocity in a $95 \% \mathrm{CO} / 5 \%$ $\mathrm{H}_{2} /$ air flame, equivalence ratio $=2.5$; (c) Sensitivity with respect to flame velocity in a $95 \% \mathrm{CO} / 5 \% \mathrm{H}_{2} /$ air flame, equivalence ratio $=5.0$.

time is defined as the time at which the $\mathrm{OH}$ concentration reaches a given value, in this case $2.5 \times 10^{-7}$ mol dm ${ }^{-3}$.

\section{Methane/Air Laminar Flame Speed}

Figure 7 shows a comparison of experimental $[28,35]$ and computed laminar flame speeds in a methane/air flame at a pressure of one atmosphere and an unburned gas temperature of $298 \mathrm{~K}$. Figures $8 \mathrm{a}, 8 \mathrm{~b}$, and $8 \mathrm{c}$ show sensitivities with respect to flame speed at equivalence

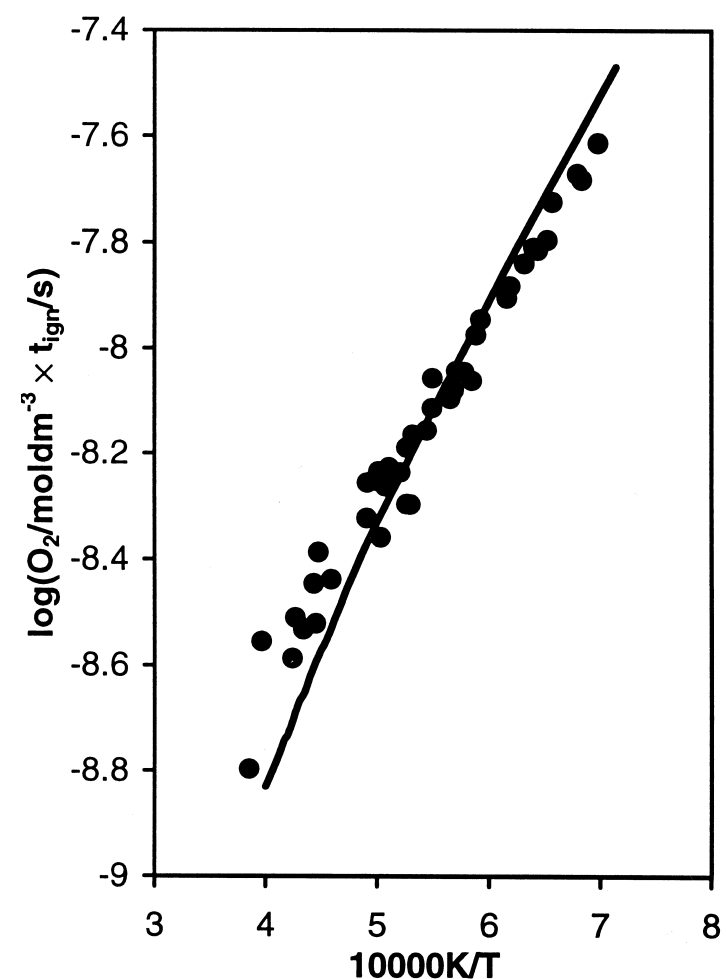

Figure 6 Function of ignition delay time vs. temperature in a $\mathrm{CO} / \mathrm{H}_{2} / \mathrm{O}_{2} / \mathrm{Ar}$ mixture. 9 , Gardiner et al. [34].

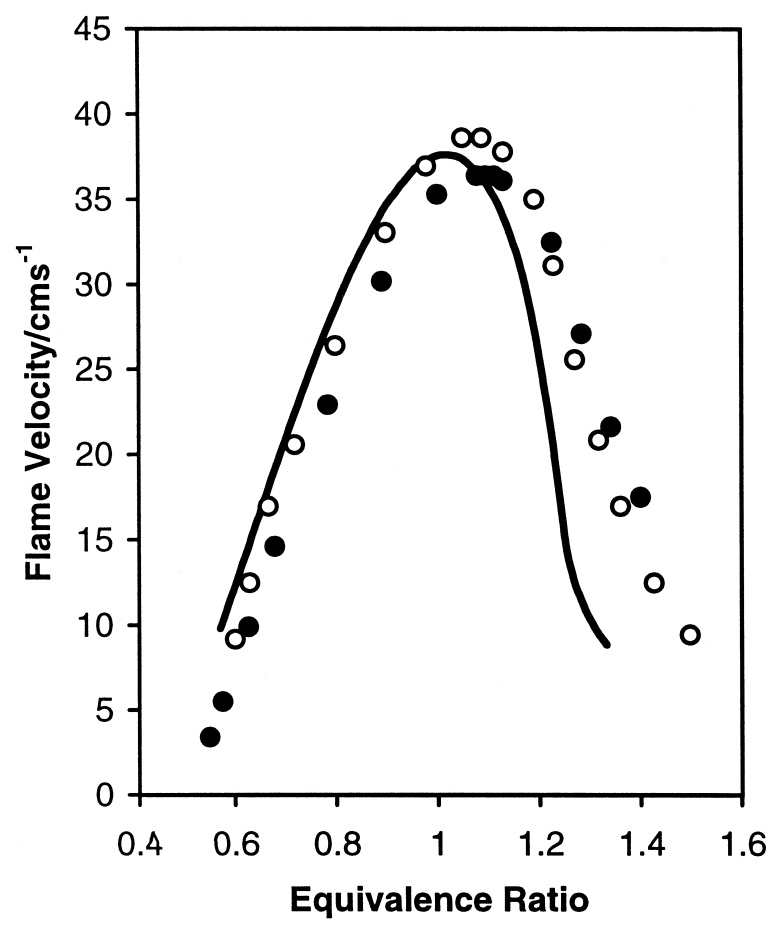

Figure 7 Flame velocity as a function of equivalence ratio for a methane/air mixture at $1 \mathrm{~atm}$ and $T_{u}=298 \mathrm{~K}$. Vagelopoulos et al. [28]. $\bigcirc$, Taylor [35]. 
(a)

$$
\begin{array}{r}
\mathrm{O}_{2}+\mathrm{H} \rightarrow \mathrm{OH}+\mathrm{O} \\
\mathrm{CO}+\mathrm{OH} \rightarrow \mathrm{CO}_{2}+\mathrm{H} \\
\mathrm{CH}_{3}+\mathrm{OH} \rightarrow \mathrm{CH}_{2}(\mathrm{~S})+\mathrm{H}_{2} \mathrm{O} \\
\mathrm{O}_{2}+\mathrm{H}+\mathrm{M} \rightarrow \mathrm{HO}_{2}+\mathrm{M} \\
\mathrm{OH}+\mathrm{O} \rightarrow \mathrm{O}_{2}+\mathrm{H} \\
\mathrm{H}+\mathrm{CH}_{3}(+\mathrm{M}) \rightarrow \mathrm{CH}_{4}(+\mathrm{M}) \\
\mathrm{HCO}+\mathrm{M} \rightarrow \mathrm{H}+\mathrm{CO}+\mathrm{M} \\
2 \mathrm{CH}_{3}(+\mathrm{M}) \rightarrow \mathrm{C}_{2} \mathrm{H}_{6}(+\mathrm{M}) \\
\mathrm{O}_{2}+\mathrm{H}+\mathrm{H}_{2} \mathrm{O} \rightarrow \mathrm{HO}_{2}+\mathrm{H}_{2} \mathrm{O} \\
\mathrm{O}+\mathrm{H}_{2} \mathrm{O} \rightarrow 2 \mathrm{OH}
\end{array}
$$

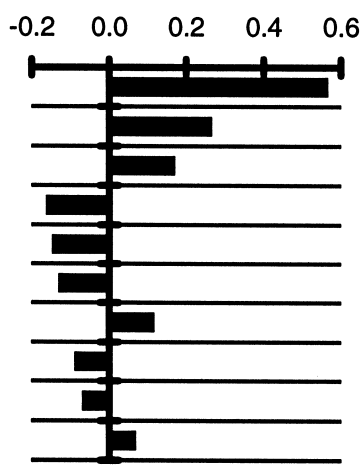

(b)

$$
\begin{array}{r}
\mathrm{O}_{2}+\mathrm{H} \rightarrow \mathrm{OH}+\mathrm{O} \\
\mathrm{H}+\mathrm{CH}_{3}(+\mathrm{M}) \rightarrow \mathrm{CH}_{4}(+\mathrm{M}) \\
\mathrm{CO}+\mathrm{OH} \rightarrow \mathrm{CO}_{2}+\mathrm{H} \\
\mathrm{CH}_{3}+\mathrm{OH} \rightarrow \mathrm{CH}_{2}(\mathrm{~S})+\mathrm{H}_{2} \mathrm{O} \\
\mathrm{OH}+\mathrm{O} \rightarrow \mathrm{O}_{2}+\mathrm{H} \\
\mathrm{CO}_{2}+\mathrm{H} \rightarrow \mathrm{CO}+\mathrm{OH} \\
\mathrm{CH}_{3}+\mathrm{O} \rightarrow \mathrm{CH}_{2} \mathrm{O}+\mathrm{H} \\
\mathrm{H}_{2}+\mathrm{OH} \rightarrow \mathrm{H}_{2} \mathrm{O}+\mathrm{H} \\
\mathrm{HCO}+\mathrm{M} \rightarrow \mathrm{H}+\mathrm{CO}+\mathrm{M} \\
\mathrm{CH}_{4}+\mathrm{H} \rightarrow \mathrm{CH}_{3}+\mathrm{H}_{2}
\end{array}
$$

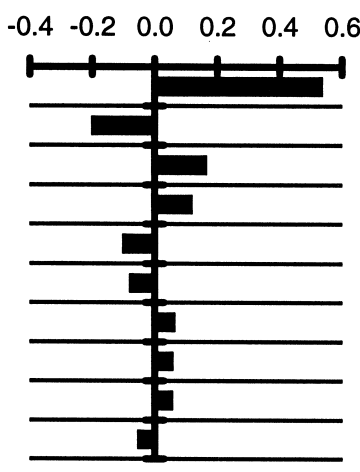

(c)

$$
\begin{array}{r}
\mathrm{O}_{2}+\mathrm{H} \rightarrow \mathrm{OH}+\mathrm{O} \\
\mathrm{H}+\mathrm{CH}_{3}(+\mathrm{M}) \rightarrow \mathrm{CH}_{4}(+\mathrm{M}) \\
\mathrm{CH}_{4}+\mathrm{H} \rightarrow \mathrm{CH}_{3}+\mathrm{H}_{2} \\
\mathrm{H}_{2}+\mathrm{CH}_{3} \rightarrow \mathrm{CH}_{4}+\mathrm{H} \\
2 \mathrm{CH}_{3} \rightarrow \mathrm{C}_{2} \mathrm{H}_{5}+\mathrm{H} \\
\mathrm{H}_{2} \mathrm{O}+\mathrm{H} \rightarrow \mathrm{H}_{2}+\mathrm{OH} \\
\mathrm{CH}_{4}+\mathrm{OH} \rightarrow \mathrm{CH}_{3}+\mathrm{H}_{2} \mathrm{O} \\
\mathrm{H}_{2}+\mathrm{OH} \rightarrow \mathrm{H}_{2} \mathrm{O}+\mathrm{H} \\
\mathrm{CO}+\mathrm{OH} \rightarrow \mathrm{CO}_{2}+\mathrm{H} \\
\mathrm{CH}_{3}+\mathrm{OH} \rightarrow \mathrm{CH}_{2}(\mathrm{~S})+\mathrm{H}_{2} \mathrm{O}
\end{array}
$$

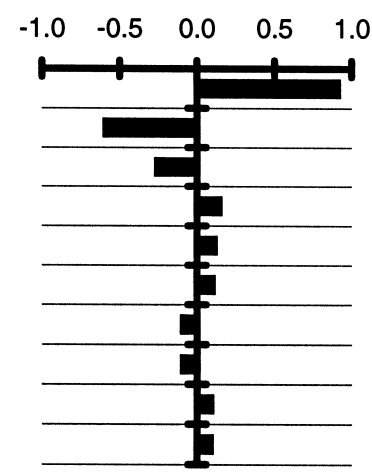

Figure 8 (a) Sensitivity with respect to flame velocity in a methane/air flame, equivalence ratio $=0.61$; (b) Sensitivity with respect to flame velocity in a methane/air flame, equivalence ratio $=1.0 ;$ (c) Sensitivity with respect to flame velocity in a methane/air flame, equivalence ratio $=1.31$.

ratios of $0.61,1.0$, and 1.31 , respectively. In addition to the alteration in the rate coefficient of reaction (8) described previously, the rate coefficient of reaction (16), $\mathrm{CH}_{3}+\mathrm{H}+\mathrm{M} \rightarrow \mathrm{CH}_{4}+\mathrm{M}$, was adjusted to modify our calculated flame speed. The CEC evaluation $[14,15]$ of this reaction is based on a limited quantity of experimental and theoretical work from Brouard et al. [36], Cobos and Troe [37], Cheng and Yeh [38], and Troe [39], and recommends that more work is required close to the low and high pressure limits to arrive at a conclusive picture. Accordingly, it quotes uncertainties of $\Delta \log k=0.3$ for both the low and high pressure limiting rate coefficients. In our simulations, the low and high pressure limiting rate coefficients of reaction (16) were set at a value of $80 \%$ of the CEC recommendation, well within the quoted uncertainty. Figure $8 \mathrm{~b}$ shows that reaction (16) is the second most important reaction with respect to laminar flame speed at an equivalence ratio of one. Also, of the top five reactions, it is the most uncertain and the only one that would not impact on the already satisfactory simulations of the hydrogen/air laminar flame speed and the hydrogen/oxygen/argon ignition delay time.

\section{Methane/Oxygen/Argon Ignition Delay Time}

The experiments of Tsuboi and Wagner [40] consisting of $0.2 \%$ methane $/ 2 \%$ oxygen $/ 97.8 \%$ argon mixtures between 21 and 29 atm, and Seery et al. [41], consisting of methane/oxygen/argon mixtures between 1.56 and $2.72 \mathrm{~atm}$ were simulated. The comparisons of the experimental data with simulations are given in Figs. 9 and $10 \mathrm{a}-10 \mathrm{c}$. To achieve the level of agreement shown, an adjustment was required in the rate

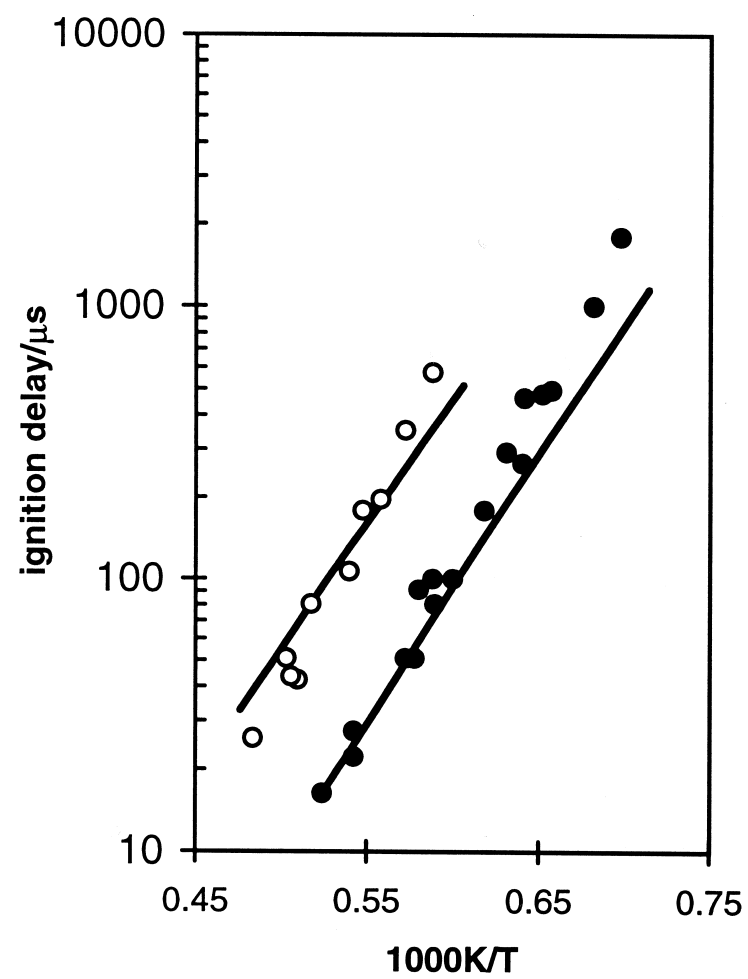

Figure 9 Ignition delay times in a $0.2 \%$ methane $/ 2 \%$ oxygen $/ 97.8 \%$ argon mixture [40]. 0 , pressure of 21-29 atm, $T=1400-2000 \mathrm{~K} ; \bigcirc$, pressure of 3-4 atm, $T=1650$ $2050 \mathrm{~K}$. 

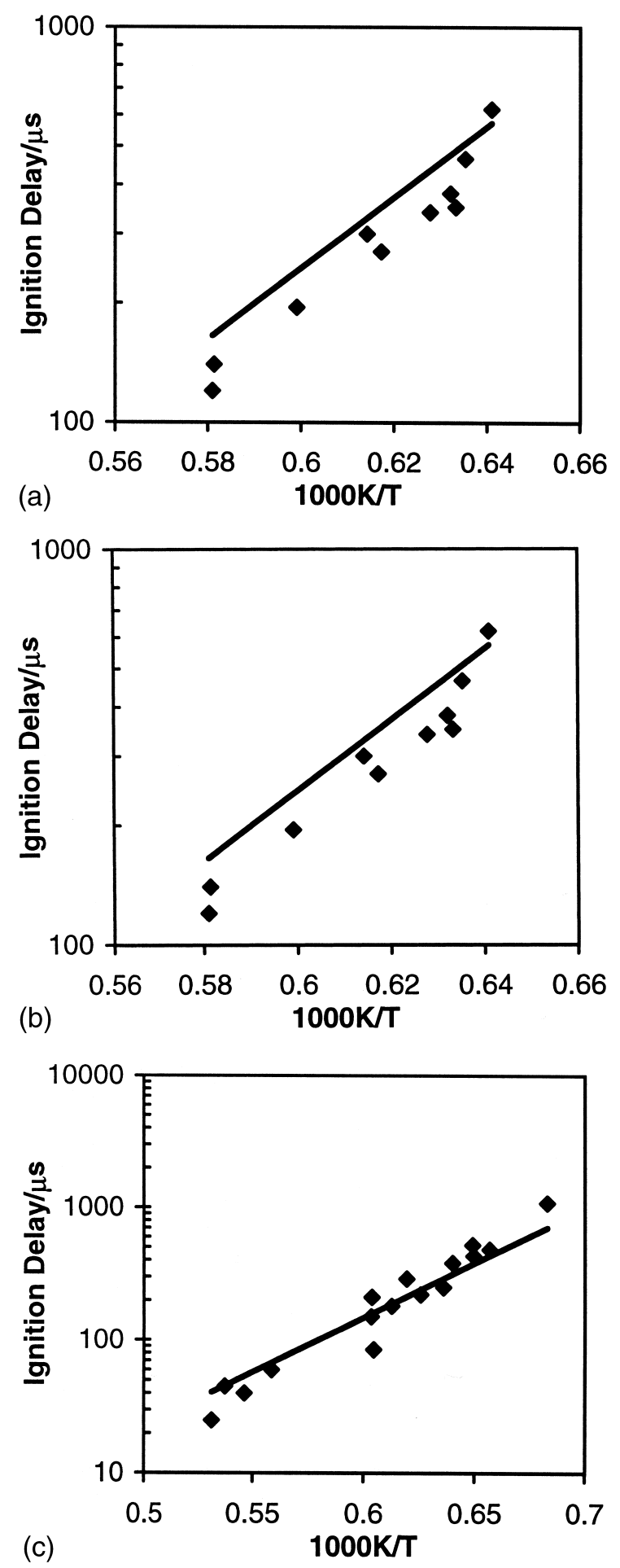

Figure 10 Ignition delay times in a $16.7 \%$ methane/16.7\% oxygen $/ 66.6 \%$ argon mixture [41]. Pressure $=1.7-1.9 \mathrm{~atm}$, equivalence ratio $=2.0$; (b) Ignition delay times in a $9.1 \%$ methane $/ 18.2 \%$ oxygen $/ 72.7 \%$ argon mixture [41]. Pressure $=1.6-2.4 \mathrm{~atm}$, equivalence ratio $=1.0 ;$ (c) Ignition delay times in a $4.8 \%$ methane $19.1 \%$ oxygen $/ 76.2 \%$ argon mixture [41]. Pressure $=1.56-2.72$ atm, equivalence ratio $=$ 0.5 . coefficient of reaction (23), $\mathrm{O}_{2}+\mathrm{CH}_{3} \rightarrow \mathrm{CH}_{3} \mathrm{O}+$ $\mathrm{O}$, reducing its rate coefficient by a factor of three from its CEC recommended value $[14,15]$. This change had no effect on the previous flame speed simulations, which are insensitive to this reaction. The CEC evaluation is based on the experimental data of Hsu et al. [42] and Saito et al. [43], which are faster than the earlier experimental data of Brabbs and Brokaw [44] and Baskharan et al. [45] by about a factor of 2.5. Therefore, our reduction of a factor of 3 , while being close to the limit of the quoted CEC evaluation uncertainty, is still compatible with some of the experimental data for this product channel.

Figures $11 \mathrm{a}-11 \mathrm{~d}$ and $12 \mathrm{a}-12 \mathrm{f}$ show sensitivities with respect to temperature at the point of ignition for the limiting temperatures of the two different pressure regimes studied by Tsuboi and Wagner [40], and of the three different stoichiometries investigated by Seery [41]. These sensitivities have a strong correlation with the importance of a particular reaction in controlling the ignition delay time. Figure 13 shows a plot of the change in ignition delay time caused by a $10 \%$ increase in each rate coefficient of the reactions in Fig. $11 \mathrm{~b}$ as a function of the temperature sensitivity. As there is no method by which the sensitivity of the ignition delay time to the reactions can be directly calculated, this empirical correlation to temperature sensitivities is extremely useful and has widespread application.

Figures $11 \mathrm{a}-11 \mathrm{~d}$ and $12 \mathrm{a}-12 \mathrm{f}$ show the importance of reaction (23) $\mathrm{CH}_{3}+\mathrm{O}_{2} \rightarrow \mathrm{CH}_{3} \mathrm{O}+\mathrm{O}$ for all conditions in these systems, after the factor of 3 reduction. It was the only reaction that could have a large enough effect on the calculated ignition delay time while keeping its change within the quoted uncertainties and not adversely affecting the other systems investigated.

\section{Ethane/Air Laminar Flame speed}

Figure 14 shows a comparison between simulations and the experimental measurements of Taylor [35] and Egolfopoulos et al. [46] of the laminar flame speed as a function of equivalence ratio in an ethane/air flame at a pressure of $1 \mathrm{~atm}$ and unburned gas temperature of $298 \mathrm{~K}$. No additional modifications to any reaction rate coefficients, beyond those already discussed, were made in obtaining the calculated fit. Figures $15 \mathrm{a}, 15 \mathrm{~b}$, and $15 \mathrm{c}$ show sensitivities with respect to laminar flame speed at equivalence ratios of $0.67,1.17$, and 1.67 , respectively. 
(a)

$$
\begin{array}{r}
\mathrm{O}_{2}+\mathrm{H} \rightarrow \mathrm{OH}+\mathrm{O} \\
\mathrm{CH}_{4}(+\mathrm{M}) \rightarrow \mathrm{CH}_{3}+\mathrm{H}(+\mathrm{M}) \\
\mathrm{O}_{2}+\mathrm{CH}_{3} \rightarrow \mathrm{CH}_{3} \mathrm{O}+\mathrm{O} \\
\mathrm{CH}_{4}+\mathrm{H} \rightarrow \mathrm{CH}_{3}+\mathrm{H}_{2} \\
\mathrm{O}_{2}+\mathrm{CH}_{3} \rightarrow \mathrm{CH}_{2} \mathrm{O}+\mathrm{OH} \\
\mathrm{CH}_{3}+\mathrm{OH} \rightarrow \mathrm{CH}_{2}(\mathrm{~S})+\mathrm{H}_{2} \mathrm{O} \\
\mathrm{H}+\mathrm{CH}_{3}(+\mathrm{M}) \rightarrow \mathrm{CH}_{4}(+\mathrm{M}) \\
\mathrm{CH}_{4}+\mathrm{O} \rightarrow \mathrm{CH}_{3}+\mathrm{OH} \\
\mathrm{O}_{2}+\mathrm{CH}_{2} \rightarrow \mathrm{CO}_{2}+\mathrm{H}_{2} \\
2 \mathrm{CH}_{3}(+\mathrm{M}) \rightarrow \mathrm{C}_{2} \mathrm{H}_{6}(+\mathrm{M})
\end{array}
$$

(c)

$$
\begin{array}{r}
\mathrm{CH}_{4}(+\mathrm{M}) \rightarrow \mathrm{CH}_{3}+\mathrm{H}(+\mathrm{M}) \\
\mathrm{O}_{2}+\mathrm{H} \rightarrow \mathrm{OH}+\mathrm{O} \\
\mathrm{CH}_{4}+\mathrm{H} \rightarrow \mathrm{CH}_{3}+\mathrm{H}_{2} \\
\mathrm{O}_{2}+\mathrm{CH}_{3} \rightarrow \mathrm{CH}_{3} \mathrm{O}+\mathrm{O} \\
\mathrm{CH}_{3}+\mathrm{OH} \rightarrow \mathrm{CH}_{2}(\mathrm{~S})+\mathrm{H}_{2} \mathrm{O} \\
\mathrm{CH}_{4}+\mathrm{O} \rightarrow \mathrm{CH}_{3}+\mathrm{OH} \\
\mathrm{O}_{2}+\mathrm{CH}_{3} \rightarrow \mathrm{CH}_{2} \mathrm{O}+\mathrm{OH} \\
\mathrm{O}_{2}+\mathrm{CH}_{2} \rightarrow \mathrm{CO}_{2}+2 \mathrm{H} \\
\mathrm{O}_{2}+\mathrm{CH}_{2} \rightarrow \mathrm{CO}_{2}+\mathrm{H}_{2} \\
2 \mathrm{CH}_{3} \rightarrow \mathrm{C}_{2} \mathrm{H}_{5}+\mathrm{H}
\end{array}
$$
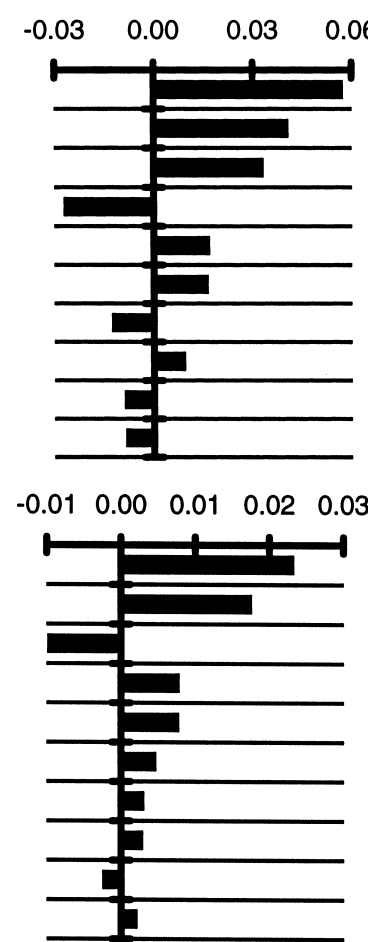

(b)

$$
\begin{array}{r}
\mathrm{O}_{2}+\mathrm{H} \rightarrow \mathrm{OH}+\mathrm{O} \\
\mathrm{O}_{2}+\mathrm{CH}_{3} \rightarrow \mathrm{CH}_{2} \mathrm{O}+\mathrm{OH} \\
2 \mathrm{CH}_{3}(+\mathrm{M}) \rightarrow \mathrm{C}_{2} \mathrm{H}_{6}(+\mathrm{M}) \\
\mathrm{O}_{2}+\mathrm{H}+\mathrm{M} \rightarrow \mathrm{HO}_{2}+\mathrm{M} \\
\mathrm{CH}_{3}+\mathrm{HO}_{2} \rightarrow \mathrm{CH}_{3} \mathrm{O}+\mathrm{OH} \\
\mathrm{O}_{2}+\mathrm{CH}_{3} \rightarrow \mathrm{CH}_{3} \mathrm{O}+\mathrm{O} \\
\mathrm{CH}_{4}+\mathrm{H} \rightarrow \mathrm{CH}_{3}+\mathrm{H}_{2} \\
\mathrm{CH}_{4}+\mathrm{OH} \rightarrow \mathrm{CH}_{3}+\mathrm{H}_{2} \mathrm{O} \\
\mathrm{CH}_{2} \mathrm{O}+\mathrm{OH} \rightarrow \mathrm{HCO}+\mathrm{H}_{2} \mathrm{O} \\
\mathrm{OH}+\mathrm{HO}_{2} \rightarrow \mathrm{H}_{2} \mathrm{O}+\mathrm{O}_{2}
\end{array}
$$

$$
\begin{array}{r}
\mathrm{O}_{2}+\mathrm{H} \rightarrow \mathrm{OH}+\mathrm{O} \\
\mathrm{O}_{2}+\mathrm{CH}_{3} \rightarrow \mathrm{CH}_{3} \mathrm{O}+\mathrm{O} \\
\mathrm{CH}_{4}(+\mathrm{M}) \rightarrow \mathrm{CH}_{3}+\mathrm{H}(+\mathrm{M}) \\
\mathrm{CH}_{4}+\mathrm{H} \rightarrow \mathrm{CH}_{3}+\mathrm{H}_{2} \\
\mathrm{O}_{2}+\mathrm{CH}_{3} \rightarrow \mathrm{CH}_{2} \mathrm{O}+\mathrm{OH} \\
\mathrm{CH}_{4}+\mathrm{OH} \rightarrow \mathrm{CH}_{3}+\mathrm{H}_{2} \mathrm{O} \\
\mathrm{CH}_{3}+\mathrm{OH} \rightarrow \mathrm{CH}_{2}(\mathrm{~S})+\mathrm{H}_{2} \mathrm{O} \\
2 \mathrm{CH}_{3}(\mathrm{M}) \rightarrow \mathrm{C}_{2} \mathrm{H}_{6}(+\mathrm{M}) \\
\mathrm{CH}_{2} \mathrm{O}+\mathrm{OH} \rightarrow \mathrm{HCO}_{+} \mathrm{H}_{2} \mathrm{O} \\
\mathrm{CH}_{2} \mathrm{O}+\mathrm{CH}_{3} \rightarrow \mathrm{CH}_{4}+\mathrm{HCO}
\end{array}
$$

Figure 11 (a) Sensitivity with respect to temperature at the point of ignition in a $0.2 \%$ methane/2\% oxygen/97.8\% argon mixture [40]. $P=29.6$ atm $T=1900 \mathrm{~K}$; (b) Sensitivity with respect to temperature at the point of ignition in a $0.2 \%$ methane/ $2 \%$ oxygen/97.8\% argon mixture [40]. $P=21.8$ atm $T=1400 \mathrm{~K}$; (c) Sensitivity with respect to temperature at the point of ignition in a $0.2 \%$ methane/2\% oxygen/97.8\% argon mixture [40]. $P=4$ atm $T=2050 \mathrm{~K}$; (d) Sensitivity with respect to temperature at the point of ignition in a $0.2 \%$ methane $/ 2 \%$ oxygen/97.8\% argon mixture [40]. $P=3.25$ atm $T=1650 \mathrm{~K}$.

\section{Ethane/Oxygen/Argon Ignition Delay Time}

To test the mechanism's prediction of ignition delay time in ethane/oxygen/argon mixtures, the data of Takahashi et al. [47], consisting of ignition delays in $1 \%$ ethane/3.5\% oxygen/95.5\% argon mixtures between 1.5-2.4 atm, and of Burcat et al. [48], consisting of ignition delays in $2 \%$ ethane, $7 \%$ oxygen, $91 \%$ argon mixtures between $6.7-8.3 \mathrm{~atm}$ was simulated. The results are shown in Figs. 16 and 17, respectively, along with Figs. 18a and 19b for the temperature sensitivities. In the CEC evaluation [14,15], products $\mathrm{CHO}+\mathrm{H}_{2} \mathrm{CO}$ are recommended for the reaction $\mathrm{O}_{2}+\mathrm{C}_{2} \mathrm{H}_{3}$ at temperatures $<1000 \mathrm{~K}$, but it is suggested that $\mathrm{HO}_{2}+\mathrm{C}_{2} \mathrm{H}_{2}$ becomes more significant at higher temperatures. Much better agreement between experiment and calculation was obtained in the present simulations if the product channel was changed to $\mathrm{HO}_{2}+\mathrm{C}_{2} \mathrm{H}_{2}$. All calculations, over the entire temperature range, have therefore been performed with this product channel. The product channel modification is the most problematic, as sensitivity analysis of a particular mechanism is obviously of no use in predicting the consequences of changing product chan- nels for a particular reaction. The low-temperature CEC evaluation is based on the experiments of Slagle et al. [49] from 291 to $606 \mathrm{~K}$, using laser flash photolysis with species detection by photoionization mass spectrometry, where no evidence for $\mathrm{HO}_{2}$ or $\mathrm{C}_{2} \mathrm{H}_{2}$ was found. The same conclusion was drawn in the end product analysis studies of Baldwin and Walker [50] at $750 \mathrm{~K}$. However, these observations do not preclude the opening of other channels at higher temperatures, and the $\mathrm{HO}_{2}+\mathrm{C}_{2} \mathrm{H}_{2}$ channel has been widely used in other mechanisms and earlier evaluations, for example, the mechanism of Konnov [11] and the evaluations of Tsang and Hampson [21] and Warnatz [22].

\section{Methane/Oxygen/Argon Flame Species Profiles}

An alternative test of the mechanism is its ability to predict species concentration profiles in flames. $\mathrm{Nu}$ merous experimental investigations have been performed with this aim, the widest range of species being covered by the work of Bernstein et al. [51] who investigated a 20 Torr stoichiometric, $12.5 \%$ methane/ 
(a)

$$
\begin{array}{r}
\mathrm{O}_{2}+\mathrm{H} \rightarrow \mathrm{OH}+\mathrm{O} \\
\mathrm{O}_{2}+\mathrm{CH}_{3} \rightarrow \mathrm{CH}_{2} \mathrm{O}+\mathrm{OH} \\
\mathrm{CH}_{4}+\mathrm{H} \rightarrow \mathrm{CH}_{3}+\mathrm{H}_{2} \\
\mathrm{O}_{2}+\mathrm{CH}_{3} \rightarrow \mathrm{CH}_{3} \mathrm{O}+\mathrm{O} \\
2 \mathrm{CH}_{3}(+\mathrm{M}) \rightarrow \mathrm{C}_{2} \mathrm{H}_{6}(+\mathrm{M}) \\
\mathrm{C}_{2} \mathrm{H}_{6}(+\mathrm{M}) \rightarrow 2 \mathrm{CH}_{3}(+\mathrm{M}) \\
\mathrm{CH}_{4}(+\mathrm{M}) \rightarrow \mathrm{CH}_{3}+\mathrm{H}(+\mathrm{M}) \\
\mathrm{H}_{2}+\mathrm{CH}_{3} \rightarrow \mathrm{CH}_{4}+\mathrm{H} \\
2 \mathrm{CH}_{3} \rightarrow \mathrm{C}_{2} \mathrm{H}_{5}+\mathrm{H} \\
\mathrm{CH}_{4}+\mathrm{O}_{2} \rightarrow \mathrm{CH}_{3}+\mathrm{HO}_{2}
\end{array}
$$

(c)

$$
\begin{array}{r}
\mathrm{O}_{2}+\mathrm{H} \rightarrow \mathrm{OH}+\mathrm{O} \\
\mathrm{O}_{2}+\mathrm{CH}_{3} \rightarrow \mathrm{CH}_{3} \mathrm{O}+\mathrm{O} \\
\mathrm{CH}_{4}+\mathrm{H} \rightarrow \mathrm{CH}_{3}+\mathrm{H}_{2} \\
\mathrm{O}_{2}+\mathrm{CH}_{3} \rightarrow \mathrm{CH}_{2} \mathrm{O}+\mathrm{OH} \\
2 \mathrm{CH}_{3}(+\mathrm{M}) \rightarrow \mathrm{C}_{2} \mathrm{H}_{6}(+\mathrm{M}) \\
\mathrm{CH}_{4}(+\mathrm{M}) \rightarrow \mathrm{CH}_{3}+\mathrm{H}(+\mathrm{M}) \\
2 \mathrm{CH}_{3} \rightarrow \mathrm{C}_{2} \mathrm{H}_{5}+\mathrm{H} \\
\left.\mathrm{C}_{2} \mathrm{H}_{6}+\mathrm{M}\right) \rightarrow 2 \mathrm{CH}_{3}(+\mathrm{M}) \\
\mathrm{CH}_{2} \mathrm{O}+\mathrm{CH}_{3} \rightarrow \mathrm{CH}_{4}+\mathrm{HCO} \\
\mathrm{CH}_{4}+\mathrm{O}_{2} \rightarrow \mathrm{CH}_{3}+\mathrm{HO}_{2}
\end{array}
$$

(e)

$$
\begin{array}{r}
\mathrm{O}_{2}+\mathrm{H} \rightarrow \mathrm{OH}+\mathrm{O} \\
\mathrm{O}_{2}+\mathrm{CH}_{3} \rightarrow \mathrm{CH}_{2} \mathrm{O}+\mathrm{OH} \\
\mathrm{O}_{2}+\mathrm{CH}_{3} \rightarrow \mathrm{CH}_{3} \mathrm{O}+\mathrm{O} \\
\mathrm{CH}_{4}+\mathrm{H} \rightarrow \mathrm{CH}_{3}+\mathrm{H}_{2} \\
2 \mathrm{CH}_{3}(+\mathrm{M}) \rightarrow \mathrm{C}_{2} \mathrm{H}_{6}(+\mathrm{M}) \\
\mathrm{CH}_{2} \mathrm{O}+\mathrm{CH}_{3} \rightarrow \mathrm{CH}_{4}+\mathrm{HCO} \\
\mathrm{CH}_{4}+\mathrm{O}_{2} \rightarrow \mathrm{CH}_{3}+\mathrm{HO}_{2} \\
\left.\left.\mathrm{CH}_{4}+\mathrm{M}\right) \rightarrow \mathrm{CH}_{3}+\mathrm{H}+\mathrm{M}\right) \\
\mathrm{CH}_{3}+\mathrm{HO}_{2} \rightarrow \mathrm{CH}_{3} \mathrm{O}+\mathrm{OH} \\
\mathrm{CH}_{4}+\mathrm{OH} \rightarrow \mathrm{CH}_{3}+\mathrm{H}_{2} \mathrm{O}
\end{array}
$$
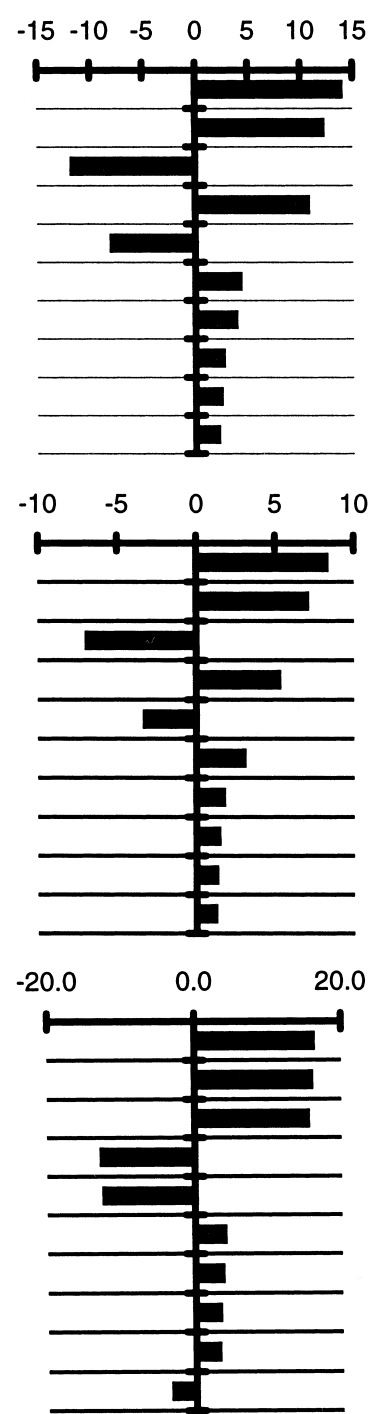

(b)

$$
\begin{aligned}
\mathrm{O}_{2}+\mathrm{CH}_{3} \rightarrow \mathrm{CH}_{2} \mathrm{O}+\mathrm{OH} \\
\mathrm{O}_{2}+\mathrm{H} \rightarrow \mathrm{OH}+\mathrm{O} \\
\left.2 \mathrm{CH}_{3}(+\mathrm{M}) \rightarrow \mathrm{C}_{2} \mathrm{H}_{6}+\mathrm{M}\right) \\
\mathrm{CH}_{4}+\mathrm{H} \rightarrow \mathrm{CH}_{3}+\mathrm{H}_{2} \\
\mathrm{O}_{2}+\mathrm{CH}_{3} \rightarrow \mathrm{CH}_{3} \mathrm{O}+\mathrm{O} \\
\mathrm{C}_{2} \mathrm{H}_{6}(+\mathrm{M}) \rightarrow 2 \mathrm{CH}_{3}(+\mathrm{M}) \\
\mathrm{CH}_{4}+\mathrm{O}_{2} \rightarrow \mathrm{CH}_{3}+\mathrm{HO}_{2} \\
\mathrm{CH}_{2} \mathrm{O}+\mathrm{CH}_{3} \rightarrow \mathrm{CH}_{4}+\mathrm{HCO} \\
\mathrm{H}_{2}+\mathrm{CH}_{3} \rightarrow \mathrm{CH}_{4}+\mathrm{H} \\
\mathrm{O}_{2}+\mathrm{CH}_{2} \mathrm{O} \rightarrow \mathrm{HCO}+\mathrm{HO}_{2}
\end{aligned}
$$

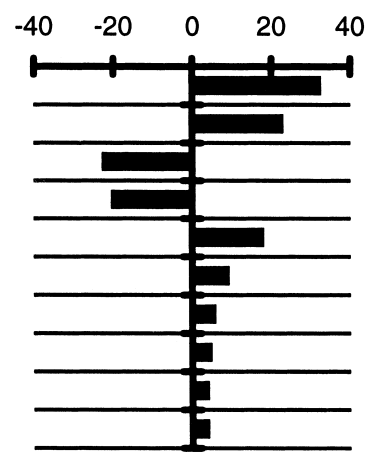

(d)

$$
\begin{aligned}
\mathrm{O}_{2}+\mathrm{CH}_{3} \rightarrow \mathrm{CH}_{2} \mathrm{O}+\mathrm{OH} \\
2 \mathrm{CH}_{3}(+\mathrm{M}) \rightarrow \mathrm{C}_{2} \mathrm{H}_{6}(+\mathrm{M}) \\
\mathrm{O}_{2}+\mathrm{H} \rightarrow \mathrm{OH}+\mathrm{O} \\
\mathrm{CH}_{4}+\mathrm{H} \rightarrow \mathrm{CH}_{3}+\mathrm{H}_{2} \\
\mathrm{O}_{2}+\mathrm{CH}_{3} \rightarrow \mathrm{CH}_{3} \mathrm{O}+\mathrm{O} \\
\mathrm{CH}_{2} \mathrm{O}+\mathrm{CH}_{3} \rightarrow \mathrm{CH}_{4}+\mathrm{HCO} \\
\mathrm{CH}_{4}+\mathrm{O}_{2} \rightarrow \mathrm{CH}_{3}+\mathrm{HO}_{2} \\
\mathrm{O}_{2}+\mathrm{CH}_{2} \mathrm{O} \rightarrow \mathrm{HCO}+\mathrm{HO}_{2} \\
\mathrm{CH}_{3}+\mathrm{HO}_{2} \rightarrow \mathrm{CH}_{3} \mathrm{O}+\mathrm{OH} \\
\mathrm{CH}_{4}+\mathrm{OH} \rightarrow \mathrm{CH}_{3}+\mathrm{H}_{2} \mathrm{O}
\end{aligned}
$$

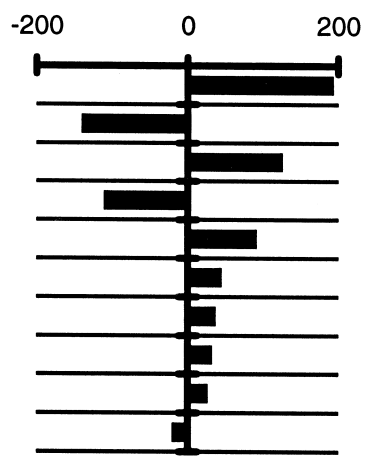

(f)

$$
\begin{aligned}
& \mathrm{O}_{2}+\mathrm{CH}_{3} \rightarrow \mathrm{CH}_{2} \mathrm{O}+\mathrm{OH} \\
& 2 \mathrm{CH}_{3}(+\mathrm{M})\left.\rightarrow \mathrm{C}_{2} \mathrm{H}_{6}+\mathrm{M}\right) \\
& \mathrm{O}_{2}+\mathrm{H} \rightarrow \mathrm{OH}+\mathrm{O} \\
& \mathrm{CH}_{4}+\mathrm{H} \rightarrow \mathrm{CH}_{3}+\mathrm{H}_{2} \mathrm{O}_{2}+\mathrm{CH}_{3} \rightarrow \mathrm{CH}_{3} \mathrm{O}+\mathrm{O} \\
& \mathrm{CH}_{3}+\mathrm{HO}_{2} \rightarrow \mathrm{CH}_{3} \mathrm{O}+\mathrm{OH} \\
& \mathrm{CH}_{2} \mathrm{O}+\mathrm{CH}_{3} \rightarrow \mathrm{CH}_{4}+\mathrm{HCO} \\
& \mathrm{CH}_{4}+\mathrm{OH} \rightarrow \mathrm{CH}_{3}+\mathrm{H}_{2} \mathrm{O} \\
& \mathrm{O}_{2}+\mathrm{CH}_{2} \mathrm{O} \rightarrow \mathrm{HCO}^{2}+\mathrm{HO}_{2} \\
& \mathrm{CH}_{4}+\mathrm{O}_{2} \rightarrow \mathrm{CH}_{3}+\mathrm{HO}_{2}
\end{aligned}
$$

Figure 12 (a) Sensitivity with respect to temperature at the point of ignition in a $16.7 \%$ methane/16.7\% oxygen/66.6\% argon mixture [41]. $\Phi=2.0 T=1881 \mathrm{~K}$; (b) Sensitivity with respect to temperature at the point of ignition in a $16.7 \%$ methane/ $16.7 \%$ oxygen/66.6\% argon mixture [41]. $\Phi=2.0, T=1464 \mathrm{~K}$; (c) Sensitivity with respect to temperature at the point of ignition in a $9.1 \%$ methane/18.2\% oxygen/72.7\% argon mixture [41]. $\Phi=1.0, T=1772 \mathrm{~K}$; (d) Sensitivity with respect to temperature at the point of ignition in a $9.1 \%$ methane/18.2\% oxygen/72.7\% argon mixture [41]. $\Phi=1.0, T=1428 \mathrm{~K}$; (e) Sensitivity with respect to temperature at the point of ignition in a $4.8 \%$ methane/19.1\% oxygen/76.2\% argon mixture [41]. $\Phi=0.5, T=1881 \mathrm{~K}$; (f) Sensitivity with respect to temperature at the point of ignition in a $4.8 \%$ methane/19.1\% oxygen/ $76.2 \%$ argon mixture [41]. $\Phi=0.5, T=1464 \mathrm{~K}$.

$25 \%$ oxygen $/ 62.5 \%$ argon flame using the techniques of LIF and REMPI to obtain relative concentration profiles for seven different species. Figures 20-26 show the comparisons between the experimental measurements and model simulations. Ordered lists of sensitivities with respect to each measured species were obtained using KINALC at selected heights above the burner surface. By imposing a cut-off of the top five most significant reactions from each list, a compilation was made of which reactions are most important in controlling the concentration profile of each species; these results are summarized in Table II.

\section{REACTION RATE COEFFICIENT COMPARISON}

A list of the highest sensitivity reactions, compiled from the simulation sensitivities, is given in Table I. Forty-two of the unmodified rate parameters for these 


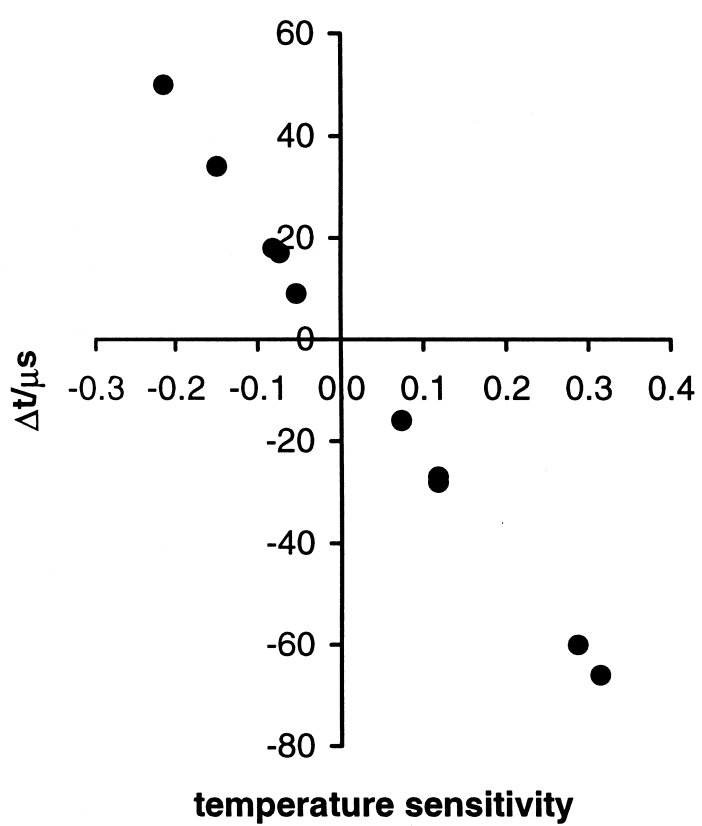

Figure 13 The change in ignition delay time caused by a $10 \%$ increase in each reaction rate coefficient as a function of the temperature sensitivity of the reaction.

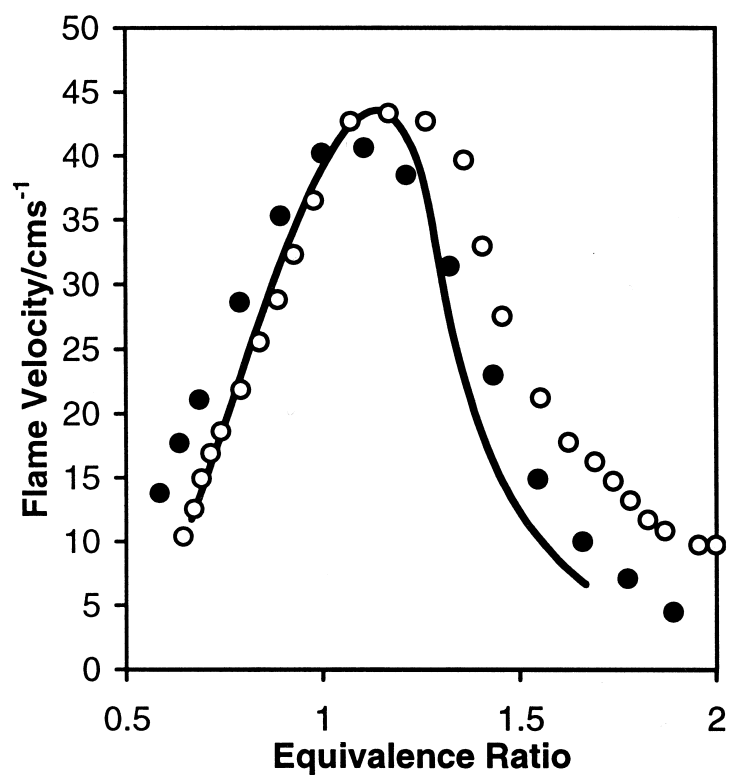

Figure 14 Flame speed as a function of equivalence ratio for an ethane/air flame at a pressure of $1 \mathrm{~atm}$ and unburned gas temperature of $298 \mathrm{~K}$. O, Taylor [35], ○, Egolfopoulos et al. [46]. (a)

$$
\begin{array}{r}
\mathrm{O}_{2}+\mathrm{H} \rightarrow \mathrm{OH}+\mathrm{O} \\
\mathrm{C}_{2} \mathrm{H}_{4}+\mathrm{O} \rightarrow \mathrm{H}+\mathrm{CH}_{2} \mathrm{HCO} \\
\mathrm{C}_{2} \mathrm{H}_{4}+\mathrm{O} \rightarrow \mathrm{CH}_{3}+\mathrm{HCO} \\
\mathrm{CO}+\mathrm{OH} \rightarrow \mathrm{CO}_{2}+\mathrm{H} \\
\mathrm{O}_{2}+\mathrm{H}+\mathrm{M} \rightarrow \mathrm{HO}_{2}+\mathrm{M} \\
\mathrm{OH}+\mathrm{O} \rightarrow \mathrm{O}_{2}+\mathrm{H} \\
\mathrm{HCO}+\mathrm{M} \rightarrow \mathrm{H}+\mathrm{CO}+\mathrm{M} \\
\mathrm{C}_{2} \mathrm{H}_{4}+\mathrm{OH} \rightarrow \mathrm{C}_{2} \mathrm{H}_{3}+\mathrm{H}_{2} \mathrm{O} \\
\mathrm{C}_{2} \mathrm{H}_{2}+\mathrm{O} \rightarrow \mathrm{CH}_{2}+\mathrm{CO} \\
\mathrm{O}+\mathrm{H}_{2} \mathrm{O} \rightarrow 2 \mathrm{OH}
\end{array}
$$

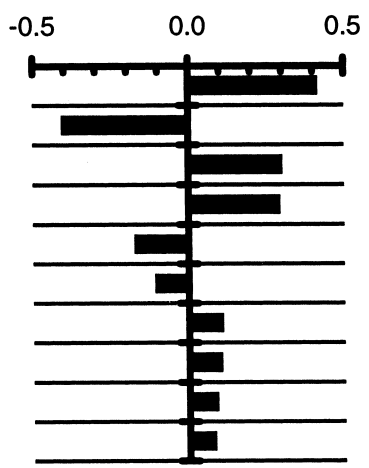

(b)

$$
\begin{aligned}
& \mathrm{O}_{2}+\mathrm{H} \rightarrow \mathrm{OH}+\mathrm{O} \\
& \mathrm{CO}+\mathrm{OH} \rightarrow \mathrm{CO}_{2}+\mathrm{H} \\
& \mathrm{H}+\mathrm{CH}_{3}(+\mathrm{M}) \rightarrow \mathrm{CH}_{4}(+\mathrm{M}) \\
& \mathrm{CO}_{2}+\mathrm{H} \rightarrow \mathrm{CO}+\mathrm{OH} \\
& \mathrm{OH}+\mathrm{O} \rightarrow \mathrm{O}_{2}+\mathrm{H} \\
& \mathrm{CH}_{3}+\mathrm{OH} \rightarrow \mathrm{CH}_{2}(\mathrm{~S})+\mathrm{H}_{2} \mathrm{O} \\
& \mathrm{C}_{2} \mathrm{H}_{2}+\mathrm{O} \rightarrow \mathrm{CH}_{2}+\mathrm{CO} \\
& \mathrm{H}_{2}+\mathrm{OH} \rightarrow \mathrm{H}_{2} \mathrm{O}+\mathrm{H} \\
& \mathrm{H}_{2} \mathrm{O}+\mathrm{H} \rightarrow \mathrm{H}_{2}+\mathrm{OH} \\
& \mathrm{H}_{2}+\mathrm{O} \rightarrow \mathrm{OH}+\mathrm{H}
\end{aligned}
$$

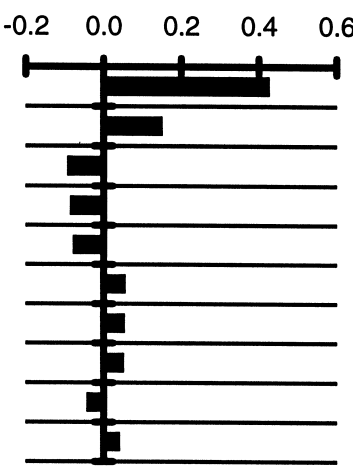

(c)

$$
\begin{array}{r}
\mathrm{O}_{2}+\mathrm{H} \rightarrow \mathrm{OH}+\mathrm{O} \\
\mathrm{H}+\mathrm{CH}_{3}(+\mathrm{M}) \rightarrow \mathrm{CH}_{4}(+\mathrm{M}) \\
\mathrm{C}_{2} \mathrm{H}_{2}+\mathrm{O} \rightarrow \mathrm{HCCO}+\mathrm{H} \\
\mathrm{H}+\mathrm{HO}_{2} \rightarrow \mathrm{H}_{2}+\mathrm{O}_{2} \\
\mathrm{CH}_{4}+\mathrm{H} \rightarrow \mathrm{CH}_{3}+\mathrm{H}_{2} \\
\mathrm{C}_{2} \mathrm{H}_{2}+\mathrm{O} \rightarrow \mathrm{CH}_{2}+\mathrm{CO} \\
\mathrm{H}_{2}+\mathrm{CH}_{3} \rightarrow \mathrm{CH}_{4}+\mathrm{H} \\
\mathrm{CH}_{3}+\mathrm{HO}_{2} \rightarrow \mathrm{CH}_{3} \mathrm{O}+\mathrm{OH} \\
\mathrm{CH}_{2} \mathrm{CO}+\mathrm{H} \rightarrow \mathrm{CH}_{3}+\mathrm{CO} \\
\mathrm{CO}+\mathrm{OH} \rightarrow \mathrm{CO}_{2}+\mathrm{H}
\end{array}
$$

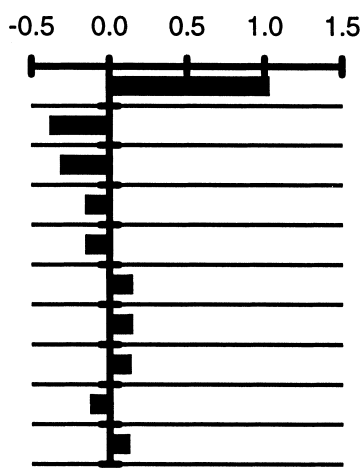

Figure 15 (a) Sensitivity with respect to flame velocity in an ethane/air flame, equivalence ratio $=0.67$; (b) Sensitivity with respect to flame velocity in an ethane/air flame, equivalence ratio $=1.17$; (c) Sensitivity with respect to flame velocity in an ethane/air flame, equivalence ratio $=1.67$.

44 reactions have been obtained from the CEC evaluated database [14,15], and the majority of the rate expressions are considered to be reliable. Therefore, there is limited scope for allowable changes to any of these rate parameters in order to obtain a better fit to the bulk experimental data, and only the four reactions discussed previously in the text have been altered.

The rate parameters for the corresponding reactions in the GRI mechanism and the mechanisms of Konnov and Chevalier are listed for comparison in Table III. Tables II and IV indicate for which experimental sys- 


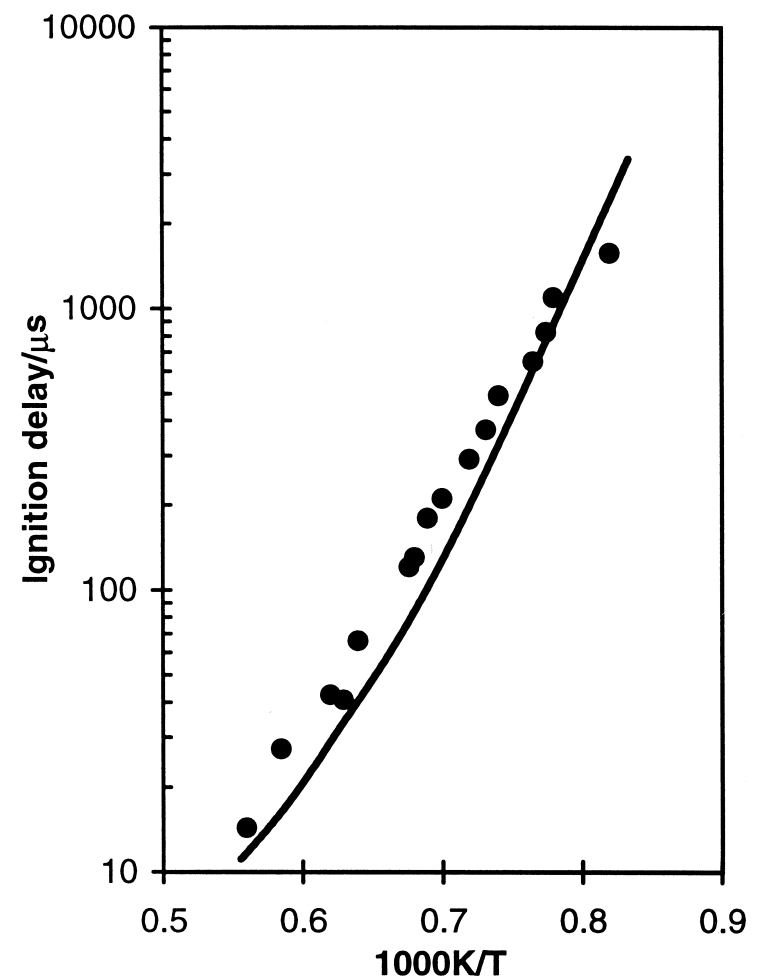

Figure 16 Ignition delay time in a $1 \%$ ethane/3.5\% oxygen $/ 95.5 \%$ argon mixture [47]. Pressure $=1.5-2.4 \mathrm{~atm}$.

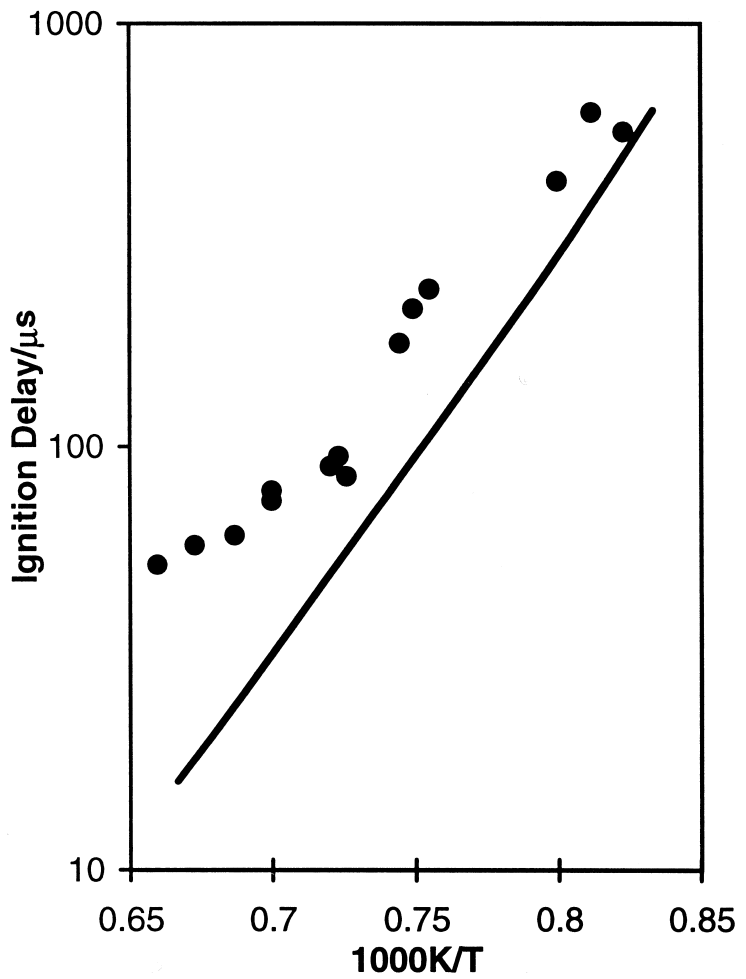

Figure 17 Ignition delay time in a $2 \%$ ethane/7\% oxygen/ $91 \%$ argon mixture [48]. Pressure $=6.7-8.3 \mathrm{~atm}$. (a)

$$
\begin{array}{r}
\mathrm{O}_{2}+\mathrm{H} \rightarrow \mathrm{OH}+\mathrm{O} \\
\mathrm{C}_{2} \mathrm{H}_{4}+\mathrm{H} \rightarrow \mathrm{C}_{2} \mathrm{H}_{3}+\mathrm{H}_{2} \\
\mathrm{H}_{2}+\mathrm{OH} \rightarrow \mathrm{H}_{2} \mathrm{O}+\mathrm{H} \\
\mathrm{C}_{2} \mathrm{H}_{2}+\mathrm{O} \rightarrow \mathrm{HCCO}+\mathrm{H} \\
\mathrm{C}_{2} \mathrm{H}_{4}+\mathrm{O} \rightarrow \mathrm{CH}_{3}+\mathrm{HCO} \\
\mathrm{H}+\mathrm{HO}_{2} \rightarrow \mathrm{H}_{2}+\mathrm{O}_{2} \\
\mathrm{CH}_{3}+\mathrm{HO}_{2} \rightarrow \mathrm{CH}_{3} \mathrm{O}+\mathrm{OH} \\
\mathrm{C}_{2} \mathrm{H}_{6}+\mathrm{H} \rightarrow \mathrm{C}_{2} \mathrm{H}_{5}+\mathrm{H}_{2} \\
\mathrm{OH}+\mathrm{HO}_{2} \rightarrow \mathrm{H}_{2} \mathrm{O}+\mathrm{O}_{2} \\
\mathrm{C}_{2} \mathrm{H}_{4}+\mathrm{OH} \rightarrow \mathrm{C}_{2} \mathrm{H}_{3}+\mathrm{H}_{2} \mathrm{O}
\end{array}
$$

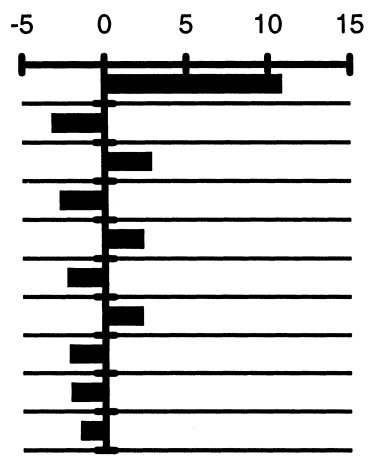

(b)

$$
\begin{array}{r}
\mathrm{O}_{2}+\mathrm{H} \rightarrow \mathrm{OH}+\mathrm{O} \\
\mathrm{C}_{2} \mathrm{H}_{6}(+\mathrm{M}) \rightarrow 2 \mathrm{CH}_{3}(+\mathrm{M}) \\
\mathrm{CH}_{3}+\mathrm{OH} \rightarrow \mathrm{CH}_{2}(\mathrm{~S})+\mathrm{H}_{2} \mathrm{O} \\
\mathrm{C}_{2} \mathrm{H}_{6}+\mathrm{H} \rightarrow \mathrm{C}_{2} \mathrm{H}_{5}+\mathrm{H}_{2} \\
\left.\mathrm{H}+\mathrm{CH}_{3}(+\mathrm{M}) \rightarrow \mathrm{CH}_{4}+\mathrm{M}\right) \\
\mathrm{H}_{2}+\mathrm{OH} \rightarrow \mathrm{H}_{2} \mathrm{O}+\mathrm{H} \\
\mathrm{C}_{2} \mathrm{H}_{6}+\mathrm{CH}_{3} \rightarrow \mathrm{C}_{2} \mathrm{H}_{5}+\mathrm{CH}_{4} \\
\mathrm{C}_{2} \mathrm{H}_{6}+\mathrm{O} \rightarrow \mathrm{C}_{2} \mathrm{H}_{5}+\mathrm{OH} \\
\mathrm{C}_{2} \mathrm{H}_{2}+\mathrm{O} \rightarrow \mathrm{CH}_{2}+\mathrm{CO} \\
\mathrm{C}_{2} \mathrm{H}_{4}+\mathrm{H} \rightarrow \mathrm{C}_{2} \mathrm{H}_{3}+\mathrm{H}_{2}
\end{array}
$$

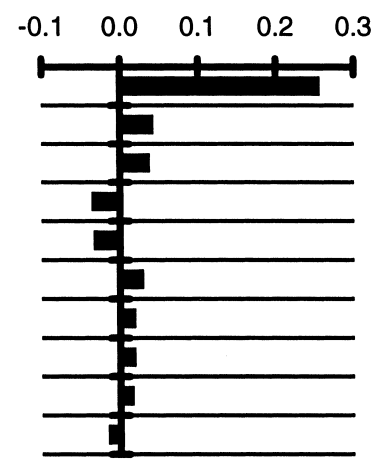

Figure 18 (a) Sensitivity with respect to temperature at the point of ignition in a $1 \%$ ethane $/ 3.5 \%$ oxygen $/ 95.5 \%$ argon mixture [47]. $T=1200 \mathrm{~K}$; (b) Sensitivity with respect to temperature at the point of ignition in a $1 \%$ ethane/3.5\% oxygen $/ 95.5 \%$ argon mixture [47]. $T=1800 \mathrm{~K}$.

tem a reaction is especially important in controlling the measured phenomena. Table IV also compares the four different mechanisms, providing an assessment of the similarity of the rate expressions to those used in the present mechanism. The assessment of the similarity of reaction rate parameters in Table IV was performed by plotting the rate coefficients as a function of temperature, and if at any point between 1000 and $2000 \mathrm{~K}$ there was a difference larger than a factor of 3 , then it was classed as being significantly different from our own. These are discussed in the following paragraphs, together with an indication of the experimental systems where they have high sensitivities.

\section{Reaction (12), $\mathrm{H}+\mathrm{CO}+\mathrm{M} \rightarrow \mathrm{HCO}+\mathrm{M}$ (Carbon Monoxide/Hydrogen/Air Laminar Flame Speed)}

Figure 27 gives the rate coefficients for reaction (12) at 1 bar as a function of temperature between 1000 and $2000 \mathrm{~K}$. The largest difference is between our rate expression and that of Chevalier at high temperature. The 
(a)

$$
\begin{array}{r}
\mathrm{O}_{2}+\mathrm{H} \rightarrow \mathrm{OH}+\mathrm{O} \\
\mathrm{C}_{2} \mathrm{H}_{6}+\mathrm{H} \rightarrow \mathrm{C}_{2} \mathrm{H}_{5}+\mathrm{H}_{2} \\
\mathrm{OH}+\mathrm{HO}_{2} \rightarrow \mathrm{H}_{2} \mathrm{O}+\mathrm{O}_{2} \\
\mathrm{H}+\mathrm{HO}_{2} \rightarrow \mathrm{H}_{2}+\mathrm{O}_{2} \\
\mathrm{C}_{2} \mathrm{H}_{4}+\mathrm{H} \rightarrow \mathrm{C}_{2} \mathrm{H}_{3}+\mathrm{H}_{2} \\
\mathrm{H}_{2}+\mathrm{OH} \rightarrow \mathrm{H}_{2} \mathrm{O}+\mathrm{H} \\
\mathrm{C}_{2} \mathrm{H}_{4}+\mathrm{O} \rightarrow \mathrm{CH}_{3}+\mathrm{HCO} \\
\mathrm{CH}_{3}+\mathrm{HO}_{2} \rightarrow \mathrm{CH}_{3} \mathrm{O}+\mathrm{OH} \\
\mathrm{O}_{2}+\mathrm{H}+\mathrm{M} \rightarrow \mathrm{HO}+\mathrm{M} \\
\mathrm{C}_{2} \mathrm{H}_{2}+\mathrm{O} \rightarrow \mathrm{HCCO}+\mathrm{H}
\end{array}
$$

(b)

$$
\begin{array}{r}
\mathrm{O}_{2}+\mathrm{H} \rightarrow \mathrm{OH}+\mathrm{O} \\
\mathrm{C}_{2} \mathrm{H}_{6}+\mathrm{H} \rightarrow \mathrm{C}_{2} \mathrm{H}_{5}+\mathrm{H}_{2} \\
\mathrm{C}_{2} \mathrm{H}_{4}+\mathrm{H} \rightarrow \mathrm{C}_{2} \mathrm{H}_{3}+\mathrm{H}_{2} \\
\mathrm{H}+\mathrm{CH}_{3}(+\mathrm{M}) \rightarrow \mathrm{CH}_{4}(+\mathrm{M}) \\
\mathrm{H}_{2}+\mathrm{OH} \rightarrow \mathrm{H}_{2} \mathrm{O}+\mathrm{H} \\
\mathrm{C}_{2} \mathrm{H}_{2}+\mathrm{O} \rightarrow \mathrm{HCCO}+\mathrm{H} \\
\mathrm{H}+\mathrm{HO}_{2} \rightarrow \mathrm{H}_{2}+\mathrm{O}_{2} \\
\mathrm{H}+\mathrm{HO}_{2} \rightarrow 2 \mathrm{OH} \\
\mathrm{C}_{2} \mathrm{H}_{5}(+\mathrm{M}) \rightarrow \mathrm{C}_{2} \mathrm{H}_{4}+\mathrm{H}(+\mathrm{M}) \\
\mathrm{C}_{2} \mathrm{H}_{3}(+\mathrm{M}) \rightarrow \mathrm{C}_{2} \mathrm{H}_{2}+\mathrm{H}(+\mathrm{M})
\end{array}
$$

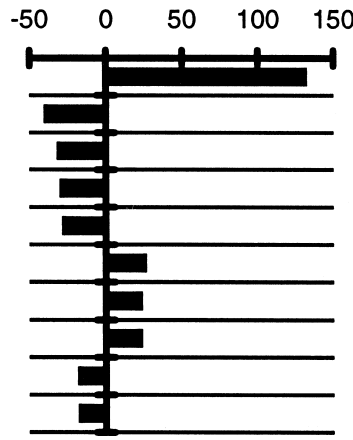

Figure 19 (a) Sensitivity with respect to temperature at the point of ignition in a $2 \%$ ethane $/ 7 \%$ oxygen/ $91 \%$ argon mixture [48], $T=1200 \mathrm{~K}$; (b) Sensitivity with respect to temperature at the point of ignition in a $2 \%$ ethane/7\% oxygen/ $91 \%$ argon mixture [48]. $T=1500 \mathrm{~K}$.

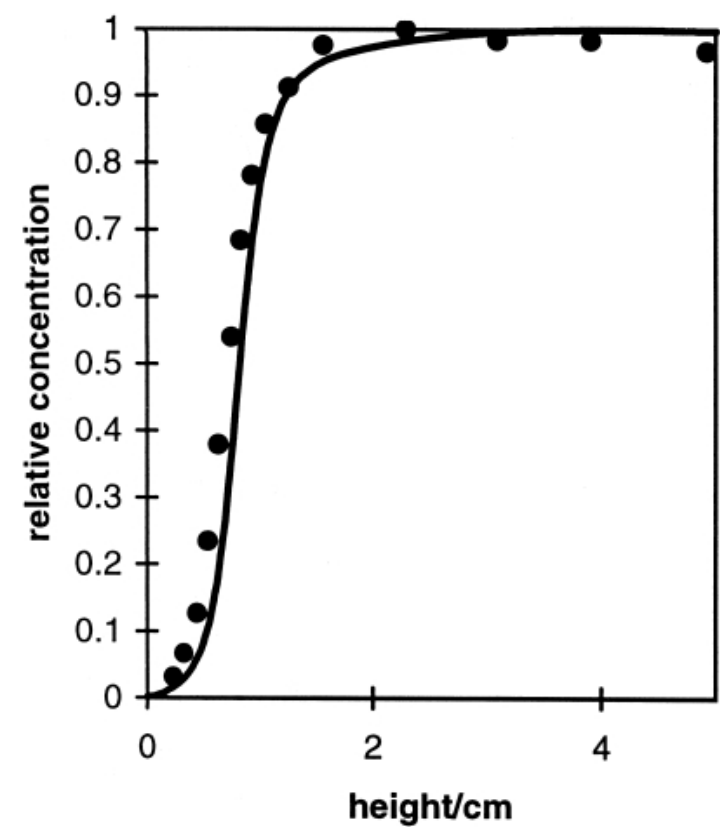

Figure 20 Relative oxygen atom concentration profile in a 20 Torr $12.5 \%$ methane $/ 25 \%$ oxygen $/ 62.5 \%$ argon flame [51].

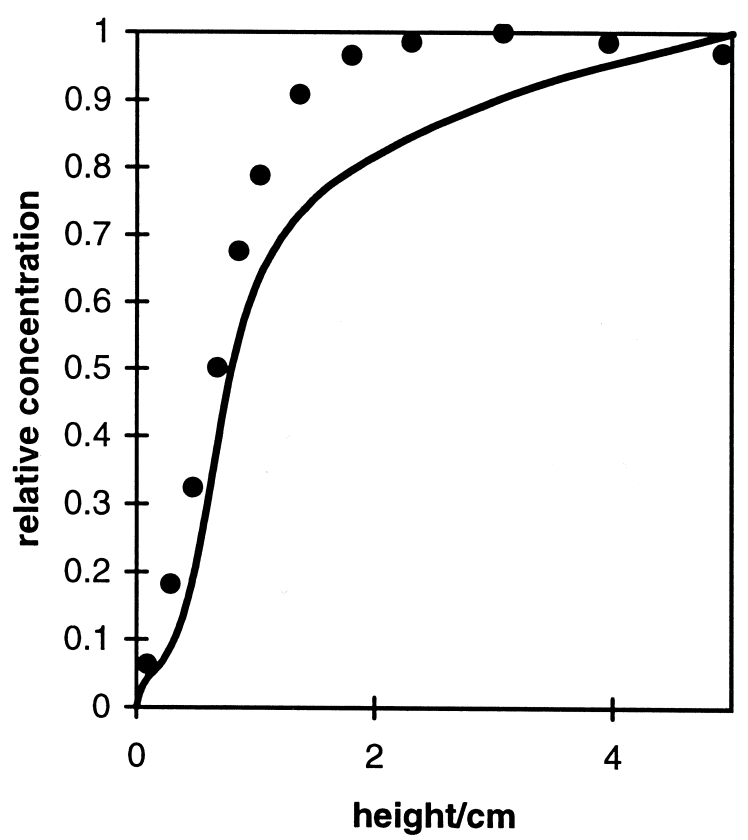

Figure 21 Relative hydrogen atom concentration profile in a 20 Torr $12.5 \%$ methane $/ 25 \%$ oxygen/ $62.5 \%$ argon flame [51].

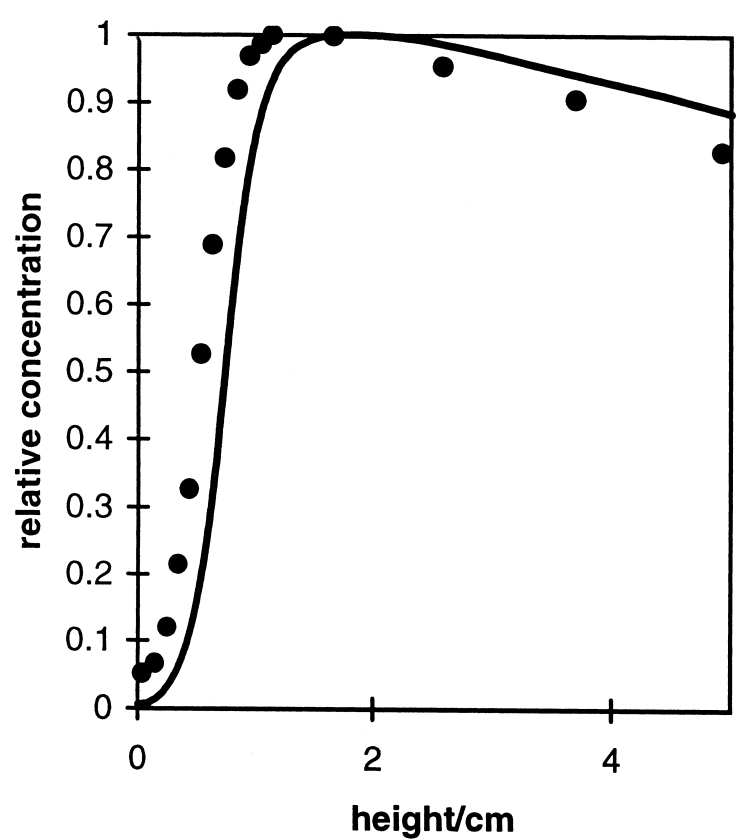

Figure 22 Relative $\mathrm{OH}$ concentration profile in a 20 Torr $12.5 \%$ methane $/ 25 \%$ oxygen $/ 62.5 \%$ argon flame [51]. 


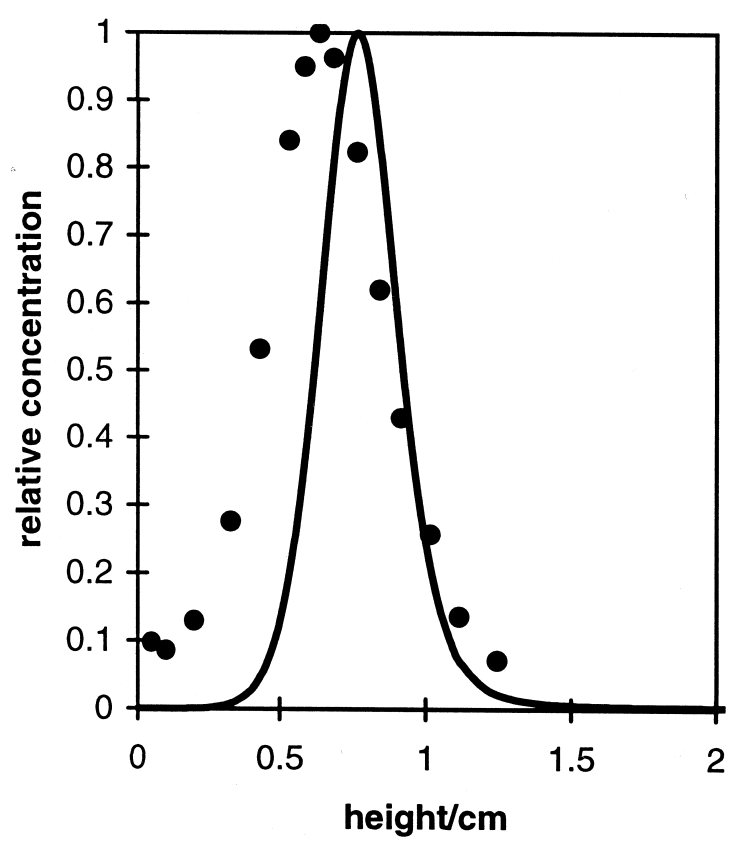

Figure 23 Relative $\mathrm{CH}$ concentration profile in a 20 Torr $12.5 \%$ methane $/ 25 \%$ oxygen/ $62.5 \%$ argon flame [51].

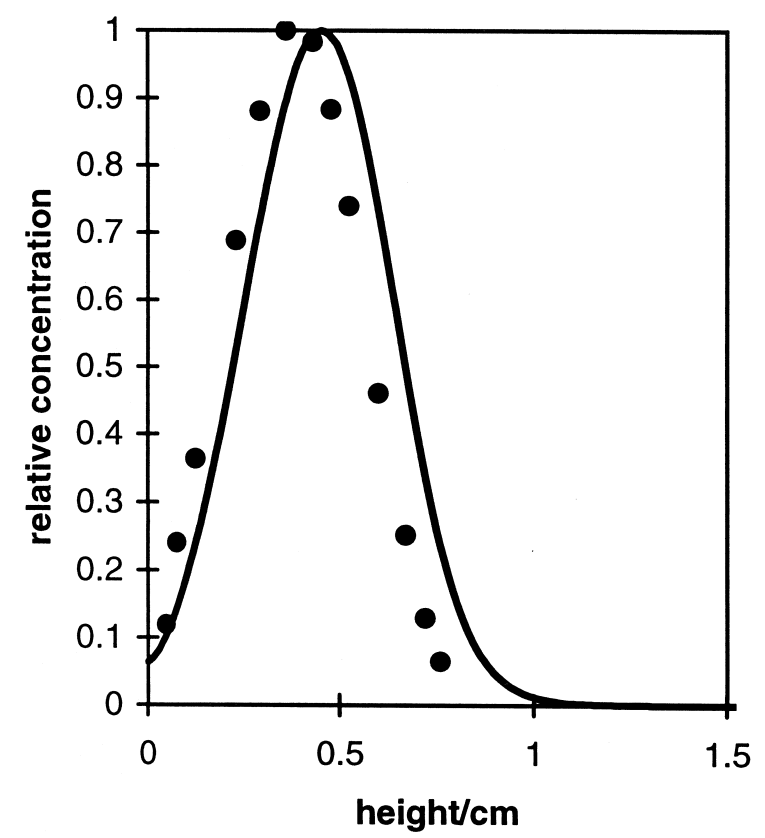

Figure 24 Relative $\mathrm{CH}_{3}$ concentration profile in a 20 Torr $12.5 \%$ methane $/ 25 \%$ oxygen $/ 62.5 \%$ argon flame [51].

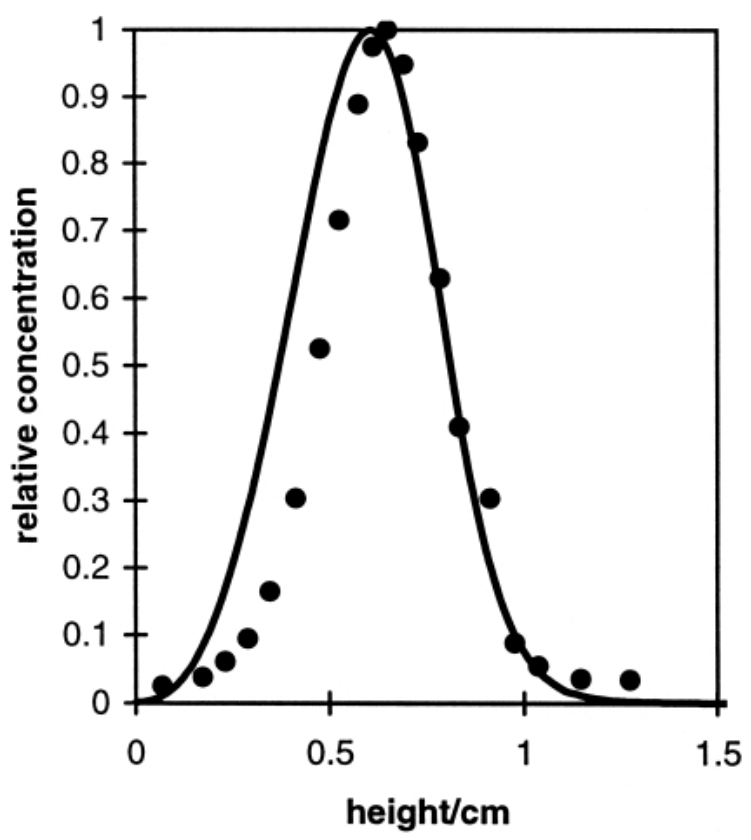

Figure 25 Relative HCO concentration profile in a 20 Torr $12.5 \%$ methane/25\% oxygen/62.5\% argon flame [51].

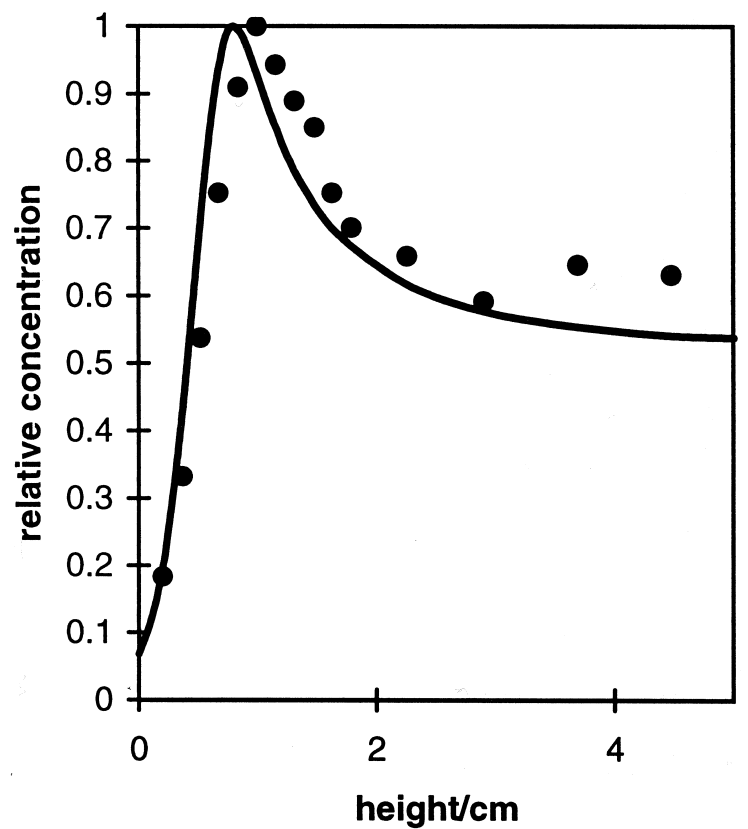

Figure 26 Relative $\mathrm{CO}$ concentration profile in a 20 Torr $12.5 \%$ methane/25\% oxygen/62.5\% argon flame [51]. 
Table II Important Reactions with Respect to Observed Species Concentration Profiles in a 20 Torr $12.5 \%$ Methane/ 25\% Oxygen/62.5\% Argon Flame

\begin{tabular}{|c|c|c|c|c|c|c|c|c|}
\hline & Reaction & $\mathrm{OH}$ & $\mathrm{H}$ & $\mathrm{O}$ & $\mathrm{CO}$ & $\mathrm{HCO}$ & $\mathrm{CH}_{3}$ & $\mathrm{CH}$ \\
\hline $\mathrm{R} 1$ & $\mathrm{H}_{2}+\mathrm{OH} \longrightarrow \mathrm{H}_{2} \mathrm{O}+\mathrm{H}$ & & $*$ & & $*$ & & & \\
\hline $\mathrm{R} 2$ & $\mathrm{O}_{2}+\mathrm{H} \longrightarrow \mathrm{OH}+\mathrm{O}$ & $*$ & $*$ & $*$ & $*$ & $*$ & $*$ & $*$ \\
\hline R3 & $\mathrm{H}_{2}+\mathrm{O} \longrightarrow \mathrm{OH}+\mathrm{H}$ & $*$ & & $*$ & & $*$ & & $*$ \\
\hline $\mathrm{R} 4$ & $\mathrm{OH}+\mathrm{O} \longrightarrow \mathrm{O}_{2}+\mathrm{H}$ & $*$ & & $*$ & & & & $*$ \\
\hline $\mathrm{R} 8$ & $\mathrm{CO}+\mathrm{OH} \longrightarrow \mathrm{CO}_{2}+\mathrm{H}$ & & $*$ & $*$ & $*$ & $*$ & & $*$ \\
\hline R9 & $\mathrm{O}+\mathrm{H}_{2} \mathrm{O} \longrightarrow 2 \mathrm{OH}$ & $*$ & & $*$ & $*$ & & & \\
\hline R10 & $2 \mathrm{OH} \longrightarrow \mathrm{O}+\mathrm{H}_{2} \mathrm{O}$ & $*$ & & $*$ & & & & \\
\hline R11 & $\mathrm{CO}_{2}+\mathrm{H} \longrightarrow \mathrm{CO}+\mathrm{OH}$ & & $*$ & & $*$ & & & \\
\hline $\mathrm{R} 13$ & $\mathrm{H}+\mathrm{HCO} \longrightarrow \mathrm{H}_{2}+\mathrm{CO}$ & $*$ & $*$ & & $*$ & $*$ & & \\
\hline R14 & $\mathrm{HCO}+\mathrm{M} \longrightarrow \mathrm{H}+\mathrm{CO}+\mathrm{M}$ & $*$ & $*$ & $*$ & $*$ & $*$ & $*$ & $*$ \\
\hline R15 & $\mathrm{CH}_{3}+\mathrm{OH} \longrightarrow{ }^{1} \mathrm{CH}_{2}+\mathrm{H}_{2} \mathrm{O}$ & & & $*$ & $*$ & $*$ & $*$ & $*$ \\
\hline R17 & $2 \mathrm{CH}_{3}+\mathrm{M} \longrightarrow \mathrm{C}_{2} \mathrm{H}_{6}+\mathrm{M}$ & & & & & & $*$ & \\
\hline $\mathrm{R} 18$ & $\mathrm{CH}_{3}+\mathrm{O} \longrightarrow \mathrm{CH}_{2} \mathrm{O}+\mathrm{H}$ & & & & $*$ & $*$ & $*$ & $*$ \\
\hline R19 & $\mathrm{CH}_{4}+\mathrm{H} \longrightarrow \mathrm{CH}_{3}+\mathrm{H}_{2}$ & & & & & & $*$ & \\
\hline R26 & $\mathrm{CH}_{4}+\mathrm{OH} \longrightarrow \mathrm{CH}_{3}+\mathrm{H}_{2} \mathrm{O}$ & & & & & & $*$ & \\
\hline R41 & $\mathrm{OH}+\mathrm{H} \longrightarrow \mathrm{H}_{2}+\mathrm{O}$ & $*$ & $*$ & & & & & \\
\hline R42 & $\mathrm{H}_{2} \mathrm{O}+\mathrm{H} \longrightarrow \mathrm{H}_{2}+\mathrm{OH}$ & & $*$ & & & & & \\
\hline $\mathrm{R} 43$ & $\mathrm{CH}_{3}+\mathrm{HCO} \longrightarrow \mathrm{CH}_{4}+\mathrm{CO}$ & & & & & $*$ & & \\
\hline $\mathrm{R} 44$ & $\mathrm{H}+{ }^{3} \mathrm{CH}_{2} \longrightarrow \mathrm{CH}+\mathrm{H}_{2}$ & & & & & & & $*$ \\
\hline
\end{tabular}

expressions for all three of the other mechanisms are derived from the reverse reaction and thermodynamics as opposed to our use of the CEC evaluation of the reaction [15].

\section{Reaction (15), $\mathrm{CH}_{3}+\mathrm{OH} \rightarrow{ }^{1} \mathrm{CH}_{2}+\mathrm{H}_{2} \mathrm{O}$ (All Systems Involving Methane and Ethane)}

Figure 28 gives the rate coefficients for reaction (15) as a function of temperature between 1000 and 2000 $\mathrm{K}$. There is a factor of 10 difference between our value and that of Konnov. At high temperatures, our value is similar to the GRI expression, which is derived from a 5 channel RRKM calculation on the methanol system. In the mechanism of Chevalier, this product channel is not present. In our simulations, we initially used an identical rate expression to that of Konnov, which we obtained from the summary page of the CEC evaluation [15]. However, we discovered this to be in error by a factor of 10 . After correction to our current value, we found that this had an adverse effect, especially on our simulation of the methane laminar flame speed under rich conditions, as can be seen in Fig. 7. Figure $8 \mathrm{c}$ shows the sensitive reactions with respect to the laminar flame velocity in the methane flame at an equivalence ratio of 1.31 , where approximately a factor of 2.5 increase in the flame speed is desired. Unfortunately, such an increase cannot be achieved by adjusting any one, or indeed any combination of the reactions listed in Fig. 8c while remaining within the currently accepted uncertainties.

\section{Reaction (16), $\mathrm{CH}_{3}+\mathrm{H}+\mathrm{M} \rightarrow \mathrm{CH}_{4}+\mathrm{M}$ (All Systems Involving Methane and Ethane)}

Figure 29 gives the rate coefficients for reaction (15) as a function of temperature between 1000 and 2000 $\mathrm{K}$, for a constant pressure of $1 \mathrm{~atm}$ of nitrogen. Our rate expression was modified to $80 \%$ of the CEC evaluation [15] for the limiting high and low pressure rate coefficients, in order to fine tune our prediction of the laminar flame speed in a stoichiometric methane/air flame. There is close agreement between our expression and that from the GRI mechanism, with only a slight diversion at the highest temperatures. The expression used in the GRI mechanism is based on an RRKM calculation by Stewart et al. [52], with a modified $k_{\infty}$ and optimized $k_{\mathrm{o}}$. The expression used in Konnov's mechanism, based on the reverse reaction and thermodynamics, has a significantly different temper- 
Table III Rate Parameters for the Reactions in Table I for the Corresponding Reactions in the GRI, Konnov, and Chevalier Mechanisms

\begin{tabular}{|c|c|c|c|c|c|c|c|c|c|}
\hline & \multicolumn{3}{|c|}{ GRI } & \multicolumn{3}{|c|}{ Konnov } & \multicolumn{3}{|c|}{ Chevalier } \\
\hline & $A$ & $n$ & $E_{a}$ & $A$ & $n$ & $E_{a}$ & $A$ & $n$ & $E_{a}$ \\
\hline $\mathrm{R} 1$ & $2.16 \times 10^{8}$ & 1.51 & 14.35 & $1.00 \times 10^{8}$ & 1.6 & 13.81 & $1.00 \times 10^{8}$ & 1.6 & 13.8 \\
\hline $\mathrm{R} 2$ & $2.65 \times 10^{16}$ & -0.67 & 71.3 & $1.00 \times 10^{14}$ & 0 & 62.11 & $2.00 \times 10^{14}$ & 0 & 70.3 \\
\hline R3 & $3.87 \times 10^{4}$ & 2.7 & 26.19 & $5.06 \times 10^{4}$ & 2.67 & 26.3 & $5.10 \times 10^{4}$ & 2.67 & 26.3 \\
\hline $\mathrm{R} 4$ & $6.96 \times 10^{13}$ & -0.27 & -0.89 & $2.66 \times 10^{11}$ & 0.4 & -10.1 & $5.19 \times 10^{11}$ & 0.4 & -1.61 \\
\hline $\mathrm{R} 5$ & $8.40 \times 10^{13}$ & 0 & 2.66 & $1.70 \times 10^{14}$ & 0 & 3.66 & $1.50 \times 10^{14}$ & 0 & 4.2 \\
\hline R6 & $2.80 \times 10^{18}$ & -0.86 & 0.0 & $1.40 \times 10^{18}$ & -0.8 & 0.0 & $2.30 \times 10^{18}$ & -0.8 & 0.0 \\
\hline R7 & $4.48 \times 10^{13}$ & 0 & 4.47 & $4.22 \times 10^{13}$ & 0 & 5.9 & $2.50 \times 10^{13}$ & 0 & 2.9 \\
\hline $\mathrm{R} 8$ & $4.76 \times 10^{7}$ & 1.23 & 0.29 & $1.17 \times 10^{74}$ & 1.35 & -3.03 & $6.00 \times 10^{6}$ & 1.5 & -3.1 \\
\hline R9 & $4.49 \times 10^{6}$ & 2.1 & 66.32 & $1.85 \times 10^{11}$ & 0.84 & 75.55 & $1.47 \times 10^{11}$ & 0.87 & 74.54 \\
\hline $\mathrm{R} 10$ & $3.57 \times 10^{4}$ & 2.4 & -8.83 & $1.50 \times 10^{9}$ & 1.14 & 0.42 & $1.50 \times 10^{9}$ & 1.14 & 0.4 \\
\hline R11 & $2.66 \times 10^{14}$ & -0.05 & 109.71 & $6.39 \times 10^{13}$ & 0.08 & 106.4 & $3.46 \times 10^{13}$ & 0.21 & 106.1 \\
\hline $\mathrm{R} 12$ & $1.18 \times 10^{15}$ & -0.35 & 1.06 & $1.02 \times 10^{12}$ & 0.64 & -4.12 & $5.02 \times 10^{12}$ & 0.64 & 1.87 \\
\hline $\mathrm{R} 13$ & $7.34 \times 10^{13}$ & 0 & 0.0 & $9.00 \times 10^{13}$ & 0 & 0.0 & $9.00 \times 10^{13}$ & 0 & 0.0 \\
\hline R14 & $1.87 \times 10^{17}$ & -1.0 & 71.13 & $1.56 \times 10^{14}$ & 0 & 65.94 & $7.10 \times 10^{14}$ & 0 & 70.3 \\
\hline R15 & $6.44 \times 10^{17}$ & -1.34 & 5.93 & $7.20 \times 10^{12}$ & 0 & 11.63 & Absent & & \\
\hline R16 & $1.39 \times 10^{16}$ & -0.63 & 2.24 & $2.88 \times 10^{9}$ & 1.38 & -15.79 & $1.90 \times 10^{36}$ & -7.0 & 38.0 \\
\hline $\mathrm{k}_{\mathrm{o}}$ & $2.62 \times 10^{33}$ & -4.76 & 10.21 & $5.39 \times 10^{10}$ & 1.38 & -74.84 & See footnote & & \\
\hline R17 & $6.77 \times 10^{16}$ & -1.18 & 2.74 & $9.21 \times 10^{16}$ & -1.17 & 2.66 & $1.70 \times 10^{53}$ & -12.0 & 81.2 \\
\hline $\mathrm{k}_{\mathrm{o}}$ & $3.40 \times 10^{41}$ & -7.03 & 11.56 & $1.13 \times 10^{36}$ & -5.25 & 7.13 & See footnote & & \\
\hline $\mathrm{R} 18$ & $5.06 \times 10^{13}$ & 0 & 0.0 & $8.43 \times 10^{13}$ & 0 & 0.0 & $8.40 \times 10^{13}$ & 0 & 0.0 \\
\hline R19 & $6.60 \times 10^{8}$ & 1.62 & 45.36 & $1.30 \times 10^{4}$ & 3.0 & 33.68 & $1.30 \times 10^{4}$ & 3.0 & 36.6 \\
\hline R20 & $2.60 \times 10^{2}$ & 3.02 & 27.06 & $5.20 \times 10^{-3}$ & 4.40 & 15.42 & $4.45 \times 10^{-1}$ & 3.83 & 24.01 \\
\hline $\mathrm{R} 21$ & $6.84 \times 10^{12}$ & 0.1 & 44.35 & $3.80 \times 10^{-7}$ & 4.84 & 32.26 & $4.02 \times 10^{8}$ & 1.08 & 36 \\
\hline $\mathrm{k}_{\mathrm{o}}$ & & & & $5.00 \times 10^{12}$ & 0.1 & 44.35 & See footnote & & \\
\hline R22 & $1.16 \times 10^{23}$ & -1.91 & 457.04 & $2.40 \times 10^{16}$ & 0 & 438.98 & $1.86 \times 10^{41}$ & -7.81 & 487.1 \\
\hline $\mathrm{k}_{\mathrm{o}}$ & $2.19 \times 10^{40}$ & -6.14 & 465.01 & $4.50 \times 10^{17}$ & 0 & 379.93 & See footnote & & \\
\hline R23 & $3.56 \times 10^{13}$ & 0 & 127.53 & $1.32 \times 10^{14}$ & 0 & 131.38 & $5.41 \times 10^{9}$ & 0.78 & 112.7 \\
\hline R24 & $1.02 \times 10^{9}$ & 1.5 & 35.98 & $7.20 \times 10^{8}$ & 1.56 & 35.5 & $6.90 \times 10^{8}$ & 1.56 & 35.5 \\
\hline R25 & $2.31 \times 10^{12}$ & 0 & 85.0 & $3.40 \times 10^{11}$ & 0 & 37.41 & $3.40 \times 10^{11}$ & 0 & 37.4 \\
\hline R26 & $1.00 \times 10^{8}$ & 1.6 & 13.05 & $1.55 \times 10^{7}$ & 1.83 & 11.61 & $1.60 \times 10^{7}$ & 1.83 & 11.6 \\
\hline $\mathrm{R} 27$ & $3.78 \times 10^{13}$ & 0 & 0.0 & $8.00 \times 10^{12}$ & 0 & 0.0 & $1.80 \times 10^{13}$ & 0 & 0.0 \\
\hline R28 & $3.43 \times 10^{9}$ & 1.18 & -1.87 & $3.43 \times 10^{9}$ & 1.18 & -1.87 & $3.40 \times 10^{9}$ & 1.18 & -1.9 \\
\hline R29 & $3.32 \times 10^{3}$ & 2.81 & 24.52 & $7.80 \times 10^{-8}$ & 6.1 & 8.24 & $1.00 \times 11^{14}$ & 0 & 25.5 \\
\hline $\mathrm{R} 30$ & $1.04 \times 10^{28}$ & -3.39 & 395.95 & $1.08 \times 10^{28}$ & -3.35 & 395.51 & $2.34 \times 10^{64}$ & -14.2 & 472.2 \\
\hline $\mathrm{k}_{\mathrm{o}}$ & $2.73 \times 10^{61}$ & -11.9 & 419.24 & $1.33 \times 10^{47}$ & -7.42 & 399.98 & See footnote & & \\
\hline R31 & $6.70 \times 10^{6}$ & 1.83 & 0.92 & $4.70 \times 10^{6}$ & 1.88 & 0.75 & $5.20 \times 10^{5}$ & 2.08 & 0.0 \\
\hline R32 & $1.25 \times 10^{7}$ & 1.83 & 0.92 & $8.10 \times 10^{6}$ & 1.88 & 0.75 & $1.20 \times 10^{6}$ & 2.08 & 0.0 \\
\hline R33 & $3.60 \times 10^{6}$ & 2.0 & 10.46 & $5.53 \times 10^{5}$ & 2.31 & 12.13 & $6.50 \times 10^{13}$ & 0 & 24.9 \\
\hline R34 & $6.94 \times 10^{6}$ & 2.0 & 7.95 & $1.20 \times 10^{6}$ & 2.1 & 6.57 & $1.70 \times 10^{4}$ & 2.8 & 2.1 \\
\hline R35 & $1.35 \times 10^{7}$ & 2.0 & 7.95 & $5.00 \times 10^{6}$ & 2.1 & 6.57 & $1.70 \times 10^{4}$ & 2.8 & 2.1 \\
\hline R36 & $1.13 \times 10^{13}$ & 0 & 14.34 & $1.80 \times 10^{13}$ & 0 & 14.23 & $3.60 \times 10^{13}$ & 0 & 14.1 \\
\hline R37 & $1.33 \times 10^{6}$ & 2.53 & 51.21 & $4.49 \times 10^{7}$ & 2.12 & 55.93 & $1.70 \times 10^{15}$ & 0 & 62.9 \\
\hline R38 & $1.15 \times 10^{8}$ & 1.9 & 31.51 & $1.40 \times 10^{9}$ & 1.5 & 30.96 & $1.40 \times 10^{9}$ & 1.50 & 31.1 \\
\hline R39 & $*$ & & & $1.90 \times 10^{16}$ & -1.0 & 0.0 & $6.00 \times 10^{13}$ & 0 & 0.0 \\
\hline $\mathrm{R} 40$ & $1.05 \times 10^{14}$ & -0.37 & 162.44 & $2.10 \times 10^{14}$ & 0 & 166.28 & $4.70 \times 10^{40}$ & -8.8 & 194.5 \\
\hline $\mathrm{k}_{\mathrm{o}}$ & $7.15 \times 10^{41}$ & -7.64 & 182.6 & $4.16 \times 10^{41}$ & -7.5 & 190.38 & See footnote & & \\
\hline R41 & $2.91 \times 10^{4}$ & 2.64 & 18.59 & $3.77 \times 10^{4}$ & 2.61 & 18.69 & $5.10 \times 10^{4}$ & 2.67 & 26.3 \\
\hline R42 & $2.04 \times 10^{10}$ & 1.14 & 81.9 & $9.19 \times 10^{9}$ & 1.24 & 81.34 & $1.00 \times 10^{8}$ & 1.6 & 13.8 \\
\hline R43 & $2.65 \times 10^{13}$ & 0 & 0.0 & $1.20 \times 10^{14}$ & 0 & 0.0 & Absent & & \\
\hline R44 & $7.94 \times 10^{14}$ & -0.20 & 0.59 & $6.00 \times 10^{12}$ & 0 & -7.53 & $6.00 \times 10^{12}$ & 0 & -7.5 \\
\hline
\end{tabular}

Pressure dependent reactions in the Chevalier mechanism all consist of specific $A T^{n} \exp \left(-E_{a} / R T\right)$ expressions for various pressures, quoted at $1 \mathrm{~atm}$ in this table.

* Sum of exponentials, $1.15 \times 108 \times \exp (2.09 \times 1000 /(8.314 \times T))+5.0 \times 10^{15} \times \exp (-72.51 \times 1000 /(8.314 \times T))$. 
Table IV Comparison of the Rate Expressions in the GRI, Konnov, and Chevalier Mechanisms to the Corresponding Rate Expressions in Our Mechanism

\begin{tabular}{|c|c|c|c|c|c|c|c|c|c|c|}
\hline & Reaction & GRI & $\mathrm{K}$ & $\mathrm{C}$ & $\mathrm{HF}$ & $\mathrm{CF}$ & MF & MI & $\mathrm{EF}$ & EI \\
\hline $\mathrm{R} 1$ & $\mathrm{H}_{2}+\mathrm{OH} \longrightarrow \mathrm{H}_{2} \mathrm{O}+\mathrm{H}$ & \# & + & + & * & $*$ & $*$ & & $*$ & $*$ \\
\hline $\mathrm{R} 2$ & $\mathrm{O}_{2}+\mathrm{H} \longrightarrow \mathrm{OH}+\mathrm{O}$ & \# & + & \# & $*$ & $*$ & $*$ & $*$ & $*$ & $*$ \\
\hline R3 & $\mathrm{H}_{2}+\mathrm{O} \longrightarrow \mathrm{OH}+\mathrm{H}$ & + & + & + & $*$ & $*$ & & & $*$ & \\
\hline $\mathrm{R} 4$ & $\mathrm{OH}+\mathrm{O} \longrightarrow \mathrm{O}_{2}+\mathrm{H}$ & $\#$ & $\#$ & + & $*$ & $*$ & $*$ & & $*$ & \\
\hline R5 & $\mathrm{H}+\mathrm{HO}_{2} \longrightarrow 2 \mathrm{OH}$ & \# & + & \# & $*$ & $*$ & & & & $*$ \\
\hline R6 & $\mathrm{O}_{2}+\mathrm{H}+\mathrm{M} \longrightarrow \mathrm{HO}_{2}+\mathrm{M}$ & \# & $\#$ & $\#$ & $*$ & $*$ & $*$ & $*$ & $*$ & $*$ \\
\hline $\mathrm{R} 7$ & $\mathrm{H}+\mathrm{HO}_{2} \longrightarrow \mathrm{H}_{2}+\mathrm{O}_{2}$ & \# & + & $\#$ & $*$ & $*$ & & & $*$ & $*$ \\
\hline $\mathrm{R} 8$ & $\mathrm{CO}+\mathrm{OH} \longrightarrow \mathrm{CO}_{2}+\mathrm{H}$ & \# & + & \# & & $*$ & $*$ & & $*$ & \\
\hline R9 & $\mathrm{O}+\mathrm{H}_{2} \mathrm{O} \longrightarrow 2 \mathrm{OH}$ & \# & \# & + & & $*$ & $*$ & & $*$ & \\
\hline $\mathrm{R} 10$ & $2 \mathrm{OH} \longrightarrow \mathrm{O}+\mathrm{H}_{2} \mathrm{O}$ & $\#$ & + & + & & $*$ & & & & \\
\hline R11 & $\mathrm{CO}_{2}+\mathrm{H} \longrightarrow \mathrm{CO}+\mathrm{OH}$ & $\#$ & $\#$ & \# & & $*$ & $*$ & & $*$ & \\
\hline R12 & $\mathrm{H}+\mathrm{CO}+\mathrm{M} \longrightarrow \mathrm{HCO}+\mathrm{M}$ & \# & $\#$ & $\mathrm{X}$ & & $*$ & & & & \\
\hline $\mathrm{R} 13$ & $\mathrm{H}+\mathrm{HCO} \longrightarrow \mathrm{H}_{2}+\mathrm{CO}$ & \# & + & + & & $*$ & & & & \\
\hline R14 & $\mathrm{HCO}+\mathrm{M} \longrightarrow \mathrm{H}+\mathrm{CO}+\mathrm{M}$ & $\#$ & + & \# & & $*$ & $*$ & & $*$ & \\
\hline $\mathrm{R} 15$ & $\mathrm{CH}_{3}+\mathrm{OH} \longrightarrow{ }^{1} \mathrm{CH}_{2}+\mathrm{H}_{2} \mathrm{O}$ & \# & $\mathrm{X}$ & - & & & $*$ & $*$ & $*$ & $*$ \\
\hline $\mathrm{R} 16$ & $\mathrm{H}+\mathrm{CH}_{3}+\mathrm{M} \longrightarrow \mathrm{CH}_{4}+\mathrm{M}$ & \# & $\mathrm{X}$ & \# & & & $*$ & $*$ & $*$ & $*$ \\
\hline $\mathrm{R} 17$ & $2 \mathrm{CH}_{3}+\mathrm{M} \longrightarrow \mathrm{C}_{2} \mathrm{H}_{6}+\mathrm{M}$ & $\#$ & \# & $\mathrm{X}$ & & & $*$ & $*$ & & \\
\hline $\mathrm{R} 18$ & $\mathrm{CH}_{3}+\mathrm{O} \longrightarrow \mathrm{CH}_{2} \mathrm{O}+\mathrm{H}$ & $\#$ & + & + & & & $*$ & & & \\
\hline R19 & $\mathrm{CH}_{4}+\mathrm{H} \longrightarrow \mathrm{CH}_{3}+\mathrm{H}_{2}$ & \# & + & \# & & & $*$ & $*$ & & \\
\hline $\mathrm{R} 20$ & $\mathrm{CH}_{3}+\mathrm{H}_{2} \longrightarrow \mathrm{CH}_{4}+\mathrm{H}$ & \# & $\#$ & \# & & & $*$ & $*$ & & \\
\hline $\mathrm{R} 21$ & $2 \mathrm{CH}_{3}+\mathrm{M} \longrightarrow \mathrm{C}_{2} \mathrm{H}_{5}+\mathrm{H}+\mathrm{M}$ & \# & $X$ & $\mathrm{X}$ & & & $*$ & $*$ & & \\
\hline $\mathrm{R} 22$ & $\mathrm{CH}_{4}+\mathrm{M} \longrightarrow \mathrm{CH}_{3}+\mathrm{H}+\mathrm{M}$ & \# & \# & \# & & & & $*$ & & \\
\hline $\mathrm{R} 23$ & $\mathrm{O}_{2}+\mathrm{CH}_{3} \longrightarrow \mathrm{CH}_{3} \mathrm{O}+\mathrm{O}$ & \# & $\mathrm{X}$ & $\mathrm{X}$ & & & & $*$ & & \\
\hline $\mathrm{R} 24$ & $\mathrm{CH}_{4}+\mathrm{O} \longrightarrow \mathrm{CH}_{3}+\mathrm{OH}$ & + & + & + & & & & $*$ & & \\
\hline $\mathrm{R} 25$ & $\mathrm{O}_{2}+\mathrm{CH}_{3} \longrightarrow \mathrm{CH}_{2} \mathrm{O}+\mathrm{OH}$ & $\#$ & $\mathrm{X}$ & $\mathrm{X}$ & & & & $*$ & & \\
\hline $\mathrm{R} 26$ & $\mathrm{CH}_{4}+\mathrm{OH} \longrightarrow \mathrm{CH}_{3}+\mathrm{H}_{2} \mathrm{O}$ & + & + & + & & & $*$ & $*$ & & \\
\hline $\mathrm{R} 27$ & $\mathrm{CH}_{3}+\mathrm{HO}_{2} \longrightarrow \mathrm{CH}_{3} \mathrm{O}+\mathrm{OH}$ & \# & \# & + & & & & $*$ & $*$ & $*$ \\
\hline $\mathrm{R} 28$ & $\mathrm{CH}_{2} \mathrm{O}+\mathrm{OH} \longrightarrow \mathrm{HCO}+\mathrm{H}_{2} \mathrm{O}$ & + & + & + & & & & $*$ & & \\
\hline R29 & $\mathrm{CH}_{2} \mathrm{O}+\mathrm{CH}_{3} \longrightarrow \mathrm{CH}_{4}+\mathrm{HCO}$ & $\mathrm{X}$ & + & $\mathrm{X}$ & & & & $*$ & & \\
\hline R30 & $\mathrm{C}_{2} \mathrm{H}_{6}+\mathrm{M} \longrightarrow 2 \mathrm{CH}_{3}+\mathrm{M}$ & $\#$ & $\mathrm{X}$ & \# & & & & $*$ & & $*$ \\
\hline $\mathrm{R} 31$ & $\mathrm{C}_{2} \mathrm{H}_{4}+\mathrm{O} \longrightarrow \mathrm{H}+\mathrm{CH}_{2} \mathrm{HCO}$ & + & + & \# & & & & & $*$ & \\
\hline R32 & $\mathrm{C}_{2} \mathrm{H}_{4}+\mathrm{O} \longrightarrow \mathrm{CH}_{3}+\mathrm{HCO}$ & + & + & \# & & & & & $*$ & $*$ \\
\hline R33 & $\mathrm{C}_{2} \mathrm{H}_{4}+\mathrm{OH} \longrightarrow \mathrm{C}_{2} \mathrm{H}_{3}+\mathrm{H}_{2} \mathrm{O}$ & \# & $\#$ & $\mathrm{X}$ & & & & & $*$ & $*$ \\
\hline $\mathrm{R} 34$ & $\mathrm{C}_{2} \mathrm{H}_{2}+\mathrm{O} \longrightarrow{ }^{3} \mathrm{CH}_{2}+\mathrm{CO}$ & \# & $\#$ & \# & & & & & $*$ & $*$ \\
\hline $\mathrm{R} 35$ & $\mathrm{C}_{2} \mathrm{H}_{2}+\mathrm{O} \longrightarrow \mathrm{HCCO}+\mathrm{H}$ & $\#$ & + & \# & & & & & $*$ & $*$ \\
\hline R36 & $\mathrm{CH}_{2} \mathrm{CO}+\mathrm{H} \longrightarrow \mathrm{CH}_{3}+\mathrm{CO}$ & \# & + & \# & & & & & $*$ & \\
\hline R37 & $\mathrm{C}_{2} \mathrm{H}_{4}+\mathrm{H} \longrightarrow \mathrm{C}_{2} \mathrm{H}_{3}+\mathrm{H}_{2}$ & \# & + & $\mathrm{X}$ & & & & & & $*$ \\
\hline R38 & $\mathrm{C}_{2} \mathrm{H}_{6}+\mathrm{H} \longrightarrow \mathrm{C}_{2} \mathrm{H}_{5}+\mathrm{H}_{2}$ & \# & + & + & & & & & & $*$ \\
\hline R39 & $\mathrm{OH}+\mathrm{HO}_{2} \longrightarrow \mathrm{H}_{2} \mathrm{O}+\mathrm{O}_{2}$ & $\#$ & $\mathrm{X}$ & $\#$ & & & & & & $*$ \\
\hline $\mathrm{R} 40$ & $\mathrm{C}_{2} \mathrm{H}_{3}+\mathrm{M} \longrightarrow \mathrm{C}_{2} \mathrm{H}_{2}+\mathrm{H}+\mathrm{M}$ & \# & \# & \# & & & & & & $*$ \\
\hline $\mathrm{R} 41$ & $\mathrm{OH}+\mathrm{H} \longrightarrow \mathrm{H}_{2}+\mathrm{O}$ & \# & \# & $\#$ & & & & & & \\
\hline $\mathrm{R} 42$ & $\mathrm{H}_{2} \mathrm{O}+\mathrm{H} \longrightarrow \mathrm{H}_{2}+\mathrm{OH}$ & + & + & + & & & & & & \\
\hline R43 & $\mathrm{CH}_{3}+\mathrm{HCO} \longrightarrow \mathrm{CH}_{4}+\mathrm{CO}$ & $\mathrm{X}$ & + & - & & & & & & \\
\hline R44 & $\mathrm{H}+{ }^{3} \mathrm{CH}_{2} \longrightarrow \mathrm{CH}+\mathrm{H}_{2}$ & $\mathrm{X}$ & + & + & & & & & & \\
\hline
\end{tabular}

GRI, GRI mechanism 3.0; K, Konnov's mechanism; C, Chevalier's mechanism.

HF, hydrogen/air laminar flame speed; CF, carbon monoxide/hydrogen/air laminar flame speed; MF, methane/air laminar flame speed; MI, methane/oxygen/argon ignition delay time; EF, ethane/air laminar flame speed; EI, ethane/oxygen/argon ignition delay time.

+ , present with identical or negligibly different rate parameters; \#, present with slightly different rate parameters; -, this reaction (or channel) is absent; $\mathrm{X}$, present with very different temperature or pressure dependence. 


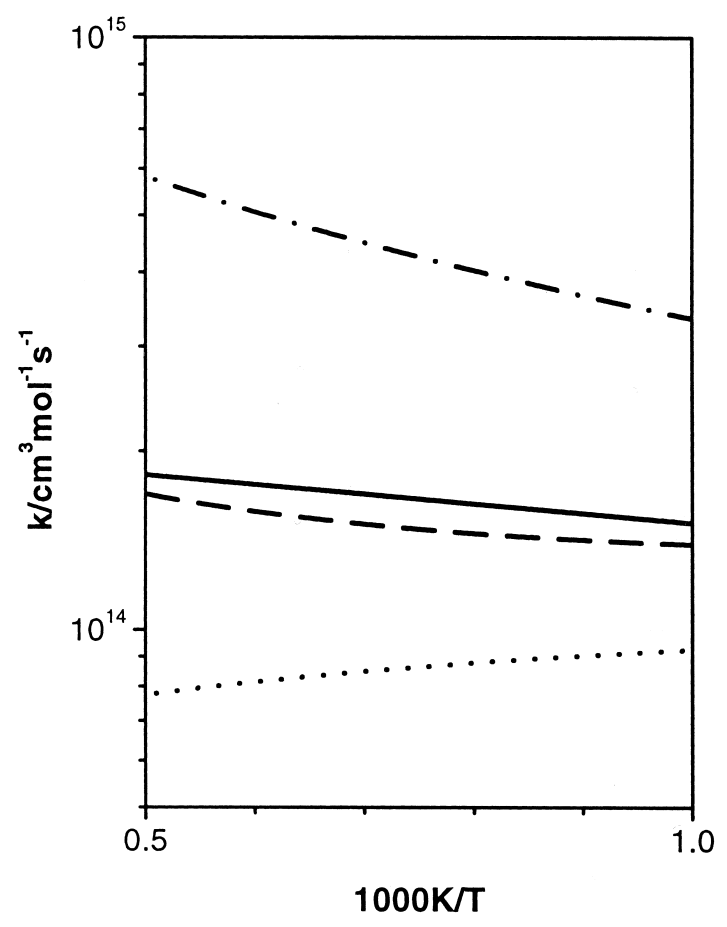

Figure 27 Rate coefficients for reaction (12) between 1000 and $2000 \mathrm{~K}$. - our mechanism; …….......... GRI mechanism; ------, Konnov's mechanism; -.........., Chevalier's mechanism.

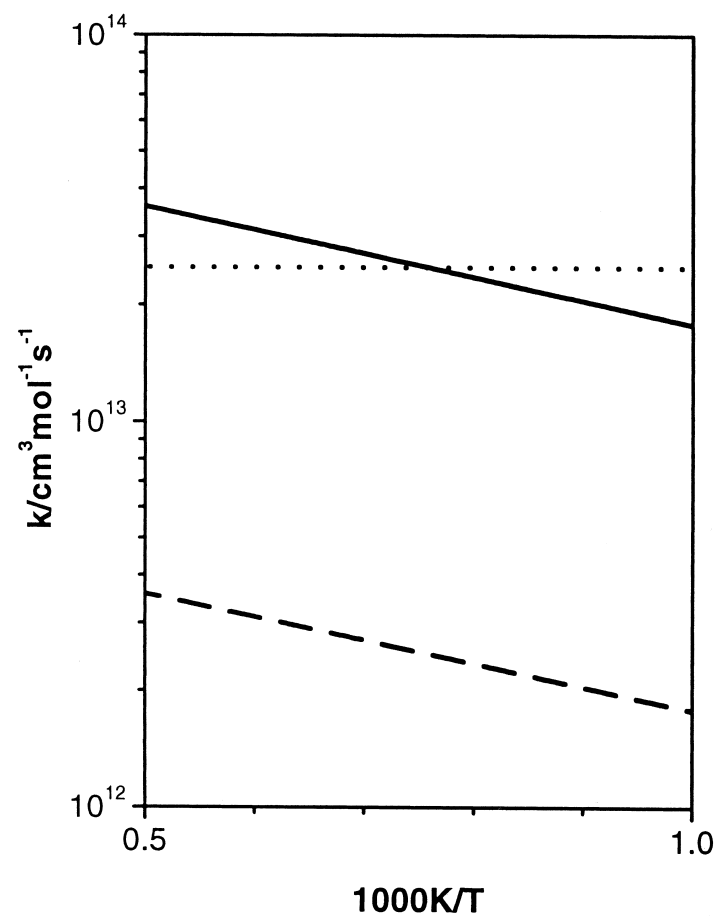

Figure 28 Rate coefficients for reaction (15) between 1000 and $2000 \mathrm{~K}$. mechanism; ------, Konnov's mechanism.

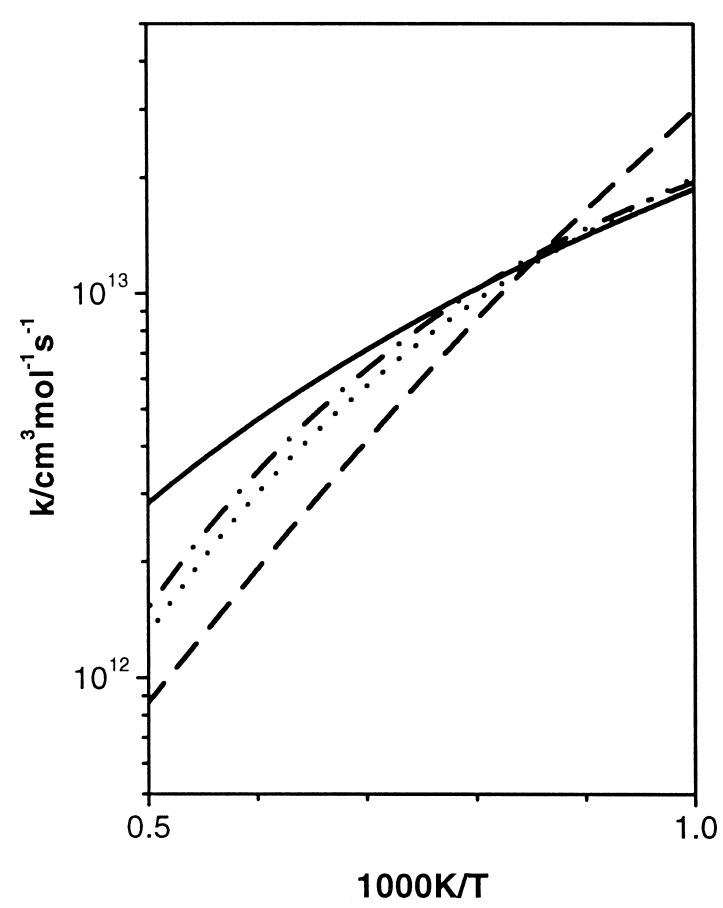

Figure 29 Rate coefficients for reaction (16) between 1000 and $2000 \mathrm{~K}$. - our mechanism; ………......, GRI mechanism; -------, Konnov's mechanism; -.........., Chevalier's mechanism.

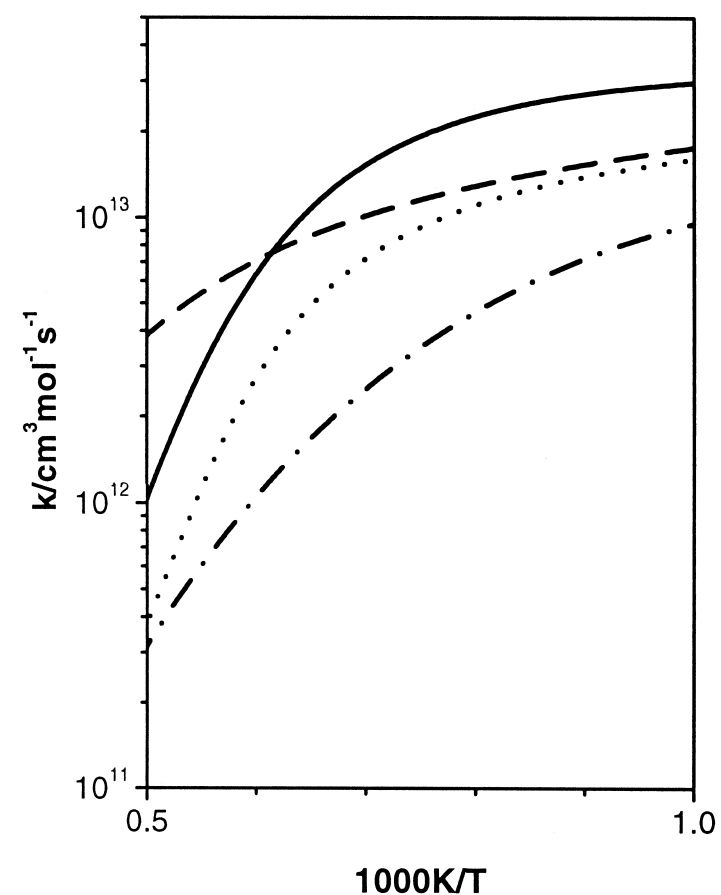

Figure 30 Rate coefficients for reaction (17) between 1000 and $2000 \mathrm{~K}$. mechanism; -------, Konnov's mechanism; -........-, Chevalier's mechanism. 


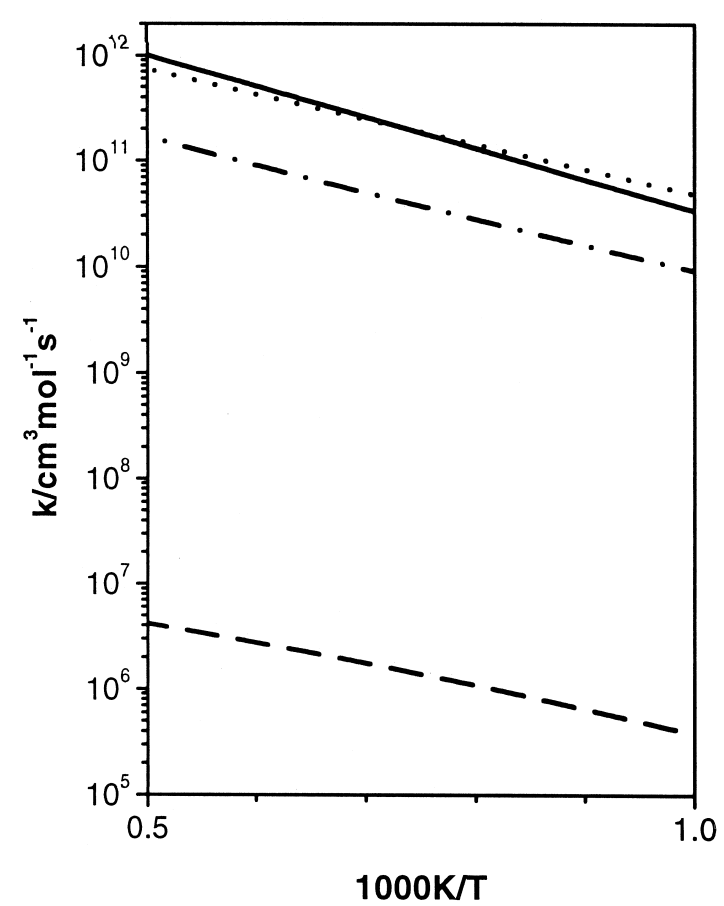

Figure 31 Rate coefficients for reaction (21) between 1000 and $2000 \mathrm{~K}$. - our mechanism; …….........., GRI mechanism; -------, Konnov's mechanism; -........., Chevalier's mechanism.

ature dependence, being faster at low temperatures, but much slower at high temperatures. The Chevalier mechanism treats pressure-dependent reactions such as this by assigning specific $A T^{n} \exp \left(-E_{a} / R T\right)$ expressions for various pressures, in this case obtained from Warnatz [22]. For most of the temperature range it provides close agreement to the expression we use.

\section{Reaction (17), $2 \mathrm{CH}_{3}+\mathrm{M} \rightarrow \mathrm{C}_{2} \mathrm{H}_{6}+\mathrm{M}$ (Methane/Air Laminar Flame Speed Simulation and the Methane/Oxygen/Argon Ignition Delay Simulations)}

Figure 30 gives the rate coefficients as a function of temperature between 1000 and $2000 \mathrm{~K}$, for a constant pressure of $1 \mathrm{~atm}$ of nitrogen. The main difference is between our expression [15], and that of Chevalier, which is obtained from Warnatz [22], with significant differences both at low and high temperatures.

Reaction (21), $2 \mathrm{CH}_{3} \rightarrow \mathrm{C}_{2} \mathrm{H}_{5}+\mathrm{H}$ (Methane/ Air Laminar Flame Speed Simulation and the Methane/Oxygen/Argon Ignition Delay Simulations)

Figure 31 gives the rate coefficients as a function of temperature between 1000 and $2000 \mathrm{~K}$. The major dif- ference concerns the Konnov rate expression, which alone among the four mechanisms is pressure dependent, and is about five orders of magnitude slower than our rate expression. This must be in error, as it is based on the same data as used to determine the value used in the GRI mechanism. Our rate expression was taken from the CEC evaluation [15]; that of the GRI mechanism is taken from Stewart et al. [53] and optimized by a $37 \%$ increase. They are similar at high temperatures and deviate at low temperatures. The expression of Chevalier is derived from the reverse reaction and thermodynamics, and is similar to our expression at low temperatures, but deviates at high temperature.

\section{Reaction (23), $\mathrm{O}_{2}+\mathrm{CH}_{3} \rightarrow \mathrm{CH}_{3} \mathrm{O}+\mathrm{O}$ (Methane/Oxygen/Argon Ignition Delay Time)}

Figure 32 gives the rate coefficients as a function of temperature between 1000 and $2000 \mathrm{~K}$. In our simulations, we found it necessary to reduce the rate of this reaction by a factor of 3 from its CEC evaluation [15] in order to get a reasonable fit to the data. The expression of Konnov uses the unmodified CEC evaluation [15], while that of the GRI mechanism is based

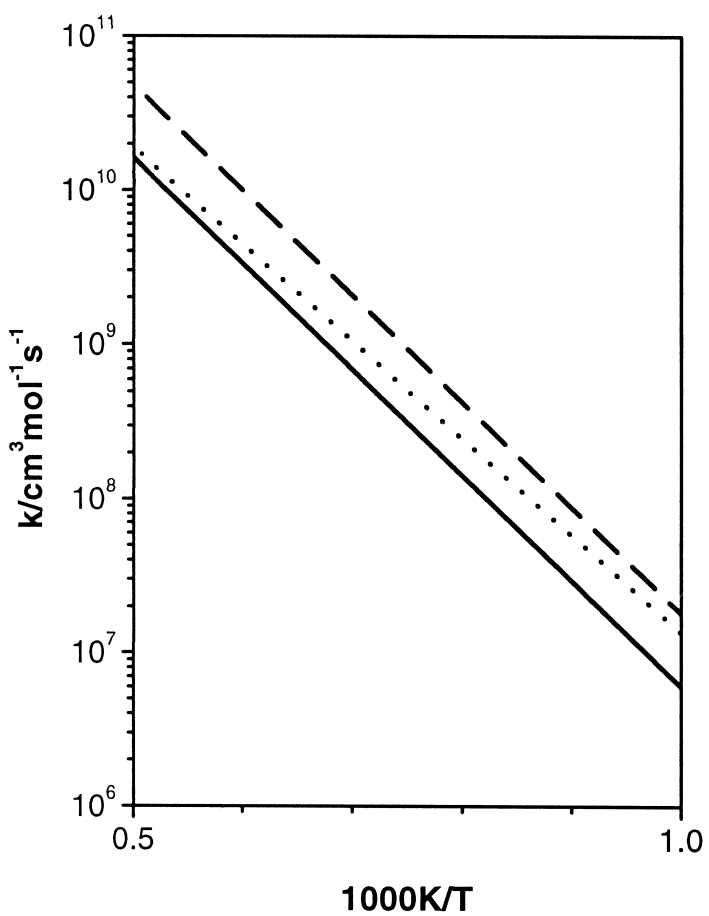

Figure 32 Rate coefficients for reaction (23) between 1000 and $2000 \mathrm{~K}$. —, our mechanism; ……........., GRI mechanism; ------, Konnov's mechanism; -........., Chevalier's mechanism. 


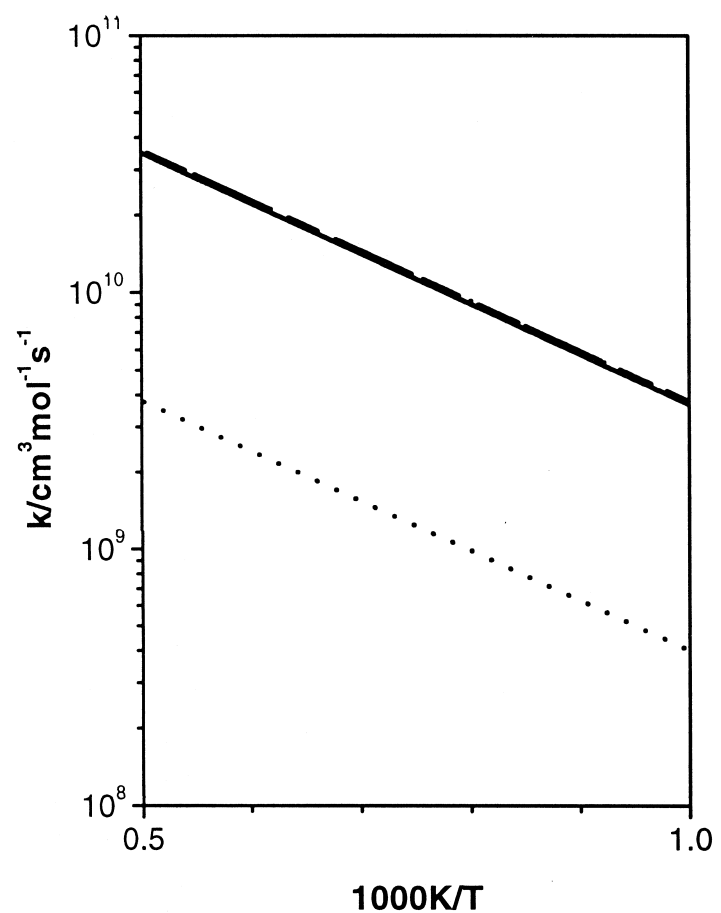

Figure 33 Rate coefficients for reaction (25) between 1000 and $2000 \mathrm{~K}$. - our mechanism; …….........., GRI mechanism; ------, Konnov's mechanism; -........-, Chevalier's mechanism.

on the work of Yu et al. [54]. It is also an optimization parameter for tuning the GRI mechanism, and is increased by $24 \%$ from its initial value in the current version [9]. The expression of Chevalier is calculated from thermodynamics and an expression for the reverse reaction from the CEC evaluation [14], and is significantly slower than the rates in the other three mechanisms.

\section{Reaction (25), $\mathrm{O}_{2}+\mathrm{CH}_{3} \rightarrow \mathrm{CH}_{2} \mathrm{O}+\mathrm{OH}$ (Methane/Oxygen/Argon Ignition Delay Time)}

Figure 33 gives the rate coefficients as a function of temperature between 1000 and $2000 \mathrm{~K}$. The expression used in our mechanism was taken from the CEC evaluation [15], and is virtually identical with those of Konnov and Chevalier. The rate expression in the GRI mechanism is based on the work of Yu et al. [54], and is slower than that from the other three mechanisms, especially at low temperature.

\section{Reaction (29), $\mathrm{CH}_{2} \mathrm{O}+\mathrm{CH}_{3} \rightarrow \mathrm{CH}_{4}+\mathrm{HCO}$ (Methane/Oxygen/Argon Ignition Delay Time)}

Figure 34 gives the rate coefficient as a function of temperature between 1000 and $2000 \mathrm{~K}$. The GRI mechanism uses a value of $60 \%$ of that recommended by Tsang and Hampson [21] in order to fit several sets of experimental data. The Chevalier mechanism uses a rate expression obtained from Warnatz [22] that at high temperatures is a factor of 300 slower than that used in both our mechanism and that of Konnov, which is obtained from the CEC evaluation [14,15].

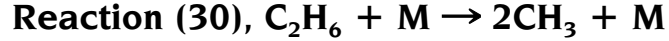 (Ignition Delay Time Simulations for Both Methane and Ethane)}

The expression in our mechanism was taken from the CEC evaluation [15], all the other three mechanisms base their expressions on the reverse reaction and thermodynamics. Figure 35 gives the rate coefficients as a function of temperature between 1000 and $2000 \mathrm{~K}$ for all four mechanisms.

\section{Reaction (33), $\mathrm{C}_{2} \mathrm{H}_{4}+\mathrm{OH} \rightarrow \mathrm{C}_{2} \mathrm{H}_{3}+\mathrm{H}_{2} \mathrm{O}$ (Experiments Involving Ethane)}

Figure 36 gives the rate coefficient as a function of temperature between 1000 and $2000 \mathrm{~K}$. The major difference is between our rate expression and that used

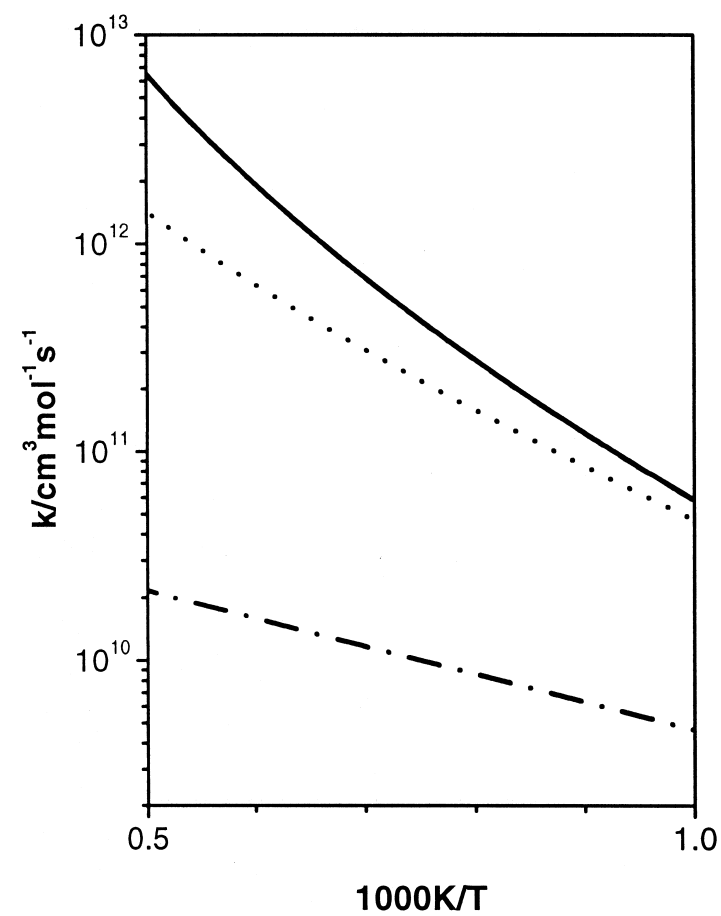

Figure 34 Rate coefficients for reaction (29) between 1000 and $2000 \mathrm{~K}$. - our mechanism; …............., GRI mechanism; -------, Konnov's mechanism; -........., Chevalier's mechanism. 


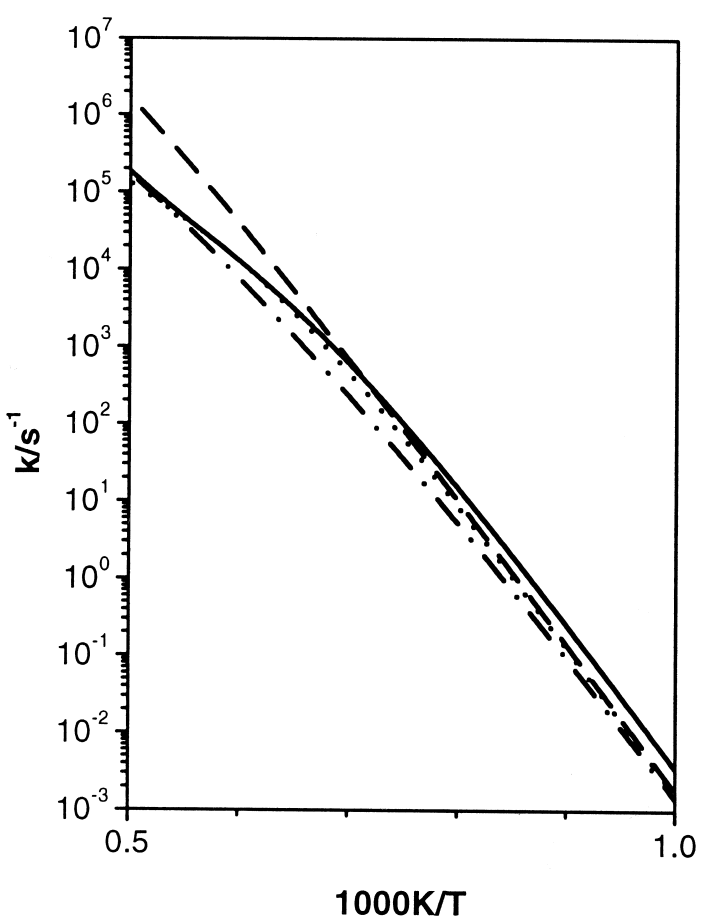

Figure 35 Rate coefficients for reaction (30) between 1000 and $2000 \mathrm{~K}$. - , our mechanism; ……........... GRI mechanism; -------, Konnov's mechanism; -.......... Chevalier's mechanism.

in the Chevalier mechanism, which is derived from the 1992 version of the CEC evaluation [14].

\section{Reaction (37), $\mathrm{C}_{2} \mathrm{H}_{4}+\mathrm{H} \rightarrow \mathrm{C}_{2} \mathrm{H}_{3}+\mathrm{H}_{2}$}

This reaction was important for the ethane/oxygen/argon ignition delay time. Figure 37 gives the rate coefficient as a function of temperature between 1000 and $2000 \mathrm{~K}$. Again, the major difference is between our rate expression and that used in the Chevalier mechanism, which is derived from the 1992 version of the CEC evaluation [14].

\section{Reaction (39), $\mathrm{OH}+\mathrm{HO}_{2} \rightarrow \mathrm{H}_{2} \mathrm{O}+\mathrm{O}_{2}$}

This reaction was important for the ethane/oxygen/argon ignition delay time. Figure 38 gives the rate coefficient as a function of temperature between 1000 and $2000 \mathrm{~K}$. The main difference occurs with the rate expression used by Konnov, which is obtained from Kim et al. [55].

\section{Reaction (43), $\mathrm{CH}_{3}+\mathrm{HCO} \rightarrow \mathrm{CH}_{4}+\mathrm{CO}$}

This reaction was important for controling the $\mathrm{HCO}$ concentration at the onset of its appearance in the flame. Figure 39 gives the rate coefficient as a func-

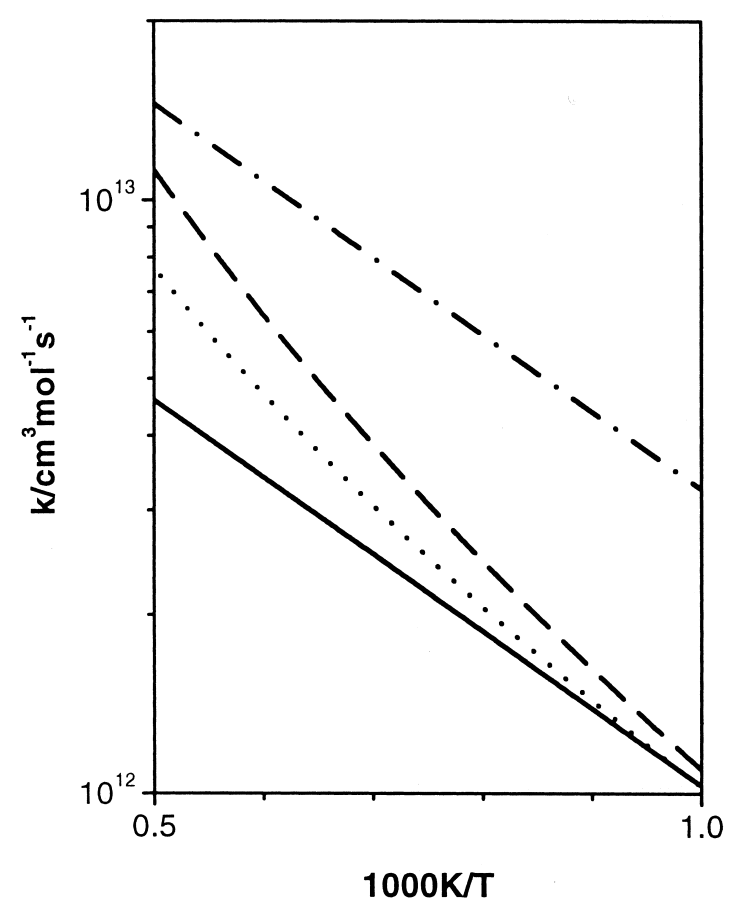

Figure 36 Rate coefficients for reaction (33) between 1000 and $2000 \mathrm{~K}$. - , our mechanism; ………....... GRI mechanism; ------, Konnov's mechanism; -.........., Chevalier's mechanism.

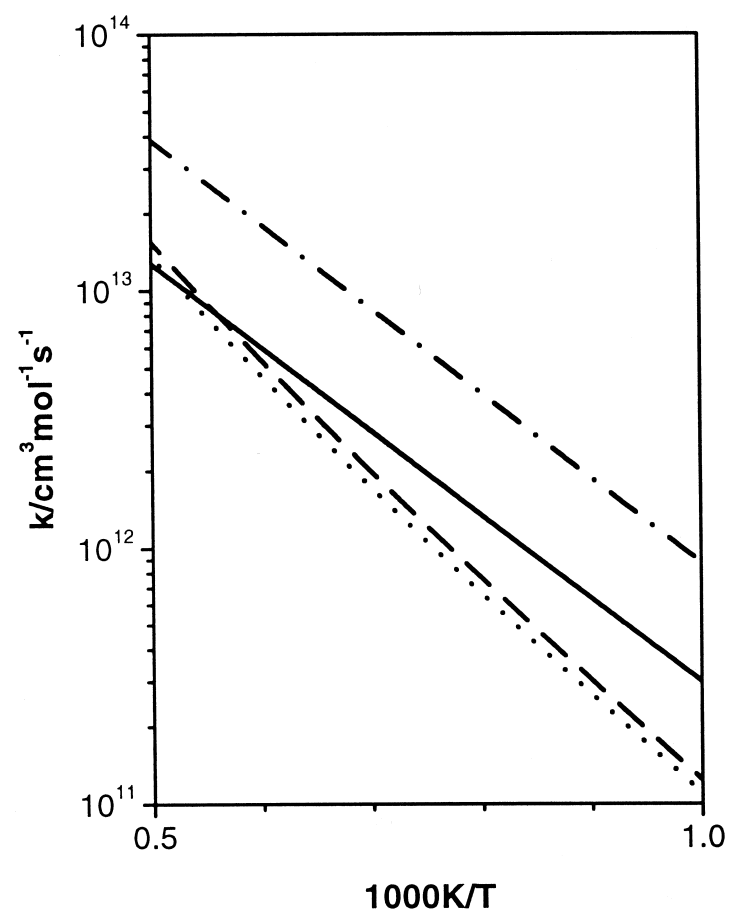

Figure 37 Rate coefficients for reaction (37) between 1000 and $2000 \mathrm{~K}$. —, our mechanism; …............, GRI mechanism; -------, Konnov's mechanism; -........-., Chevalier's mechanism. 


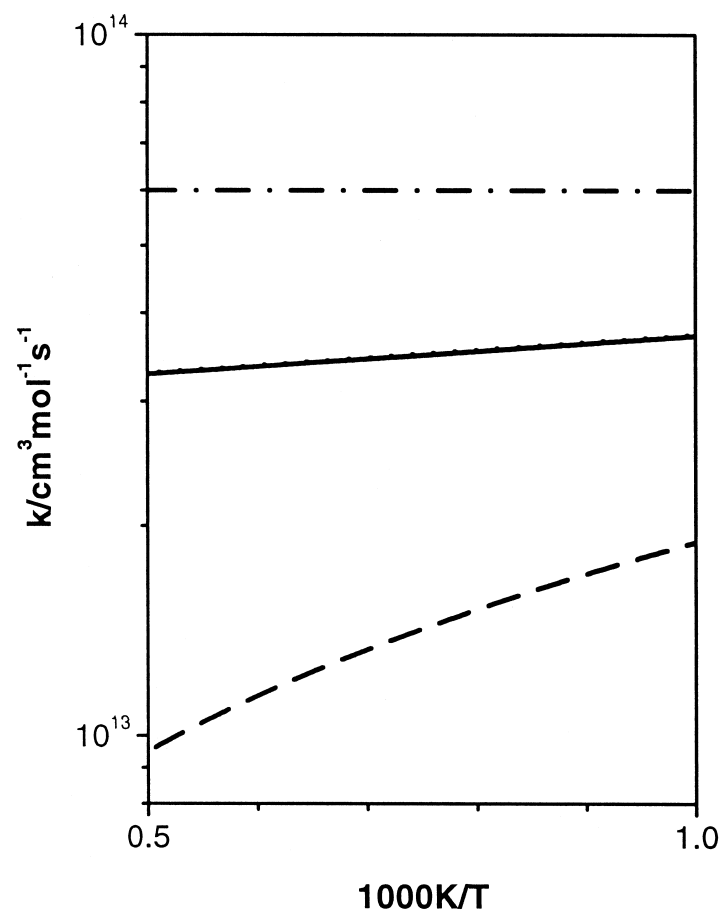

Figure 38 Rate coefficients for reaction (39) between 1000 and $2000 \mathrm{~K}$. - our mechanism; …….........., GRI mechanism; ------, Konnov's mechanism; -........-, Chevalier's mechanism.

tion of temperature between 500 and $2000 \mathrm{~K}$. The rate coefficient expression used in our mechanism and that of Konnov is taken from the literature review of Tsang and Hampson [21], whereas the GRI mechanism uses the room temperature measurement of $\mathrm{Mu}$ lenko [56].

\section{Reaction (44), $\mathrm{H}+{ }^{3} \mathrm{CH}_{2} \rightarrow \mathrm{CH}+\mathrm{H}_{2}$}

This reaction was important for controling the $\mathrm{CH}$ concentration throughout its entire concentration profile in the flame. Figure 40 gives the rate coefficient as a function of temperature between 500 and $2000 \mathrm{~K}$. The rate coefficient expressions used in our mechanism and those of Konnov and Chevalier are identical and taken from the latest CEC evaluation [15]. That used in the GRI mechanism is significantly different and is derived from the reverse reaction and thermodynamics, the reverse reaction in turn being derived from a two channel variational RRKM calculation.

\section{DISCUSSION AND CONCLUSIONS}

A comprehensively annotated mechanism has been constructed to describe the oxidation of hydrogen, car-

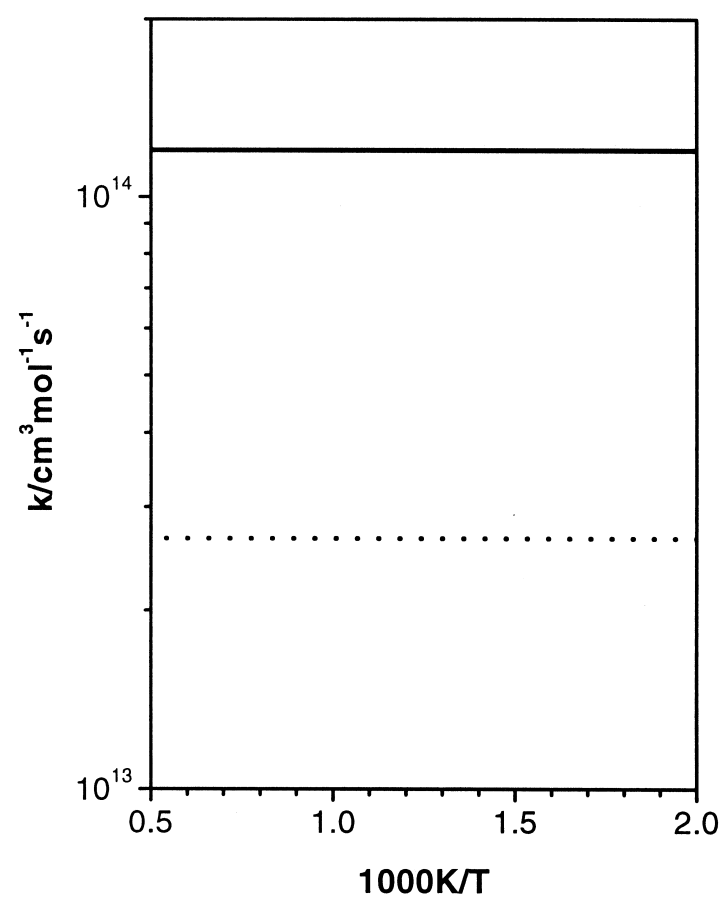

Figure 39 Rate coefficients for reaction (43) between 500 and $2000 \mathrm{~K}$. Konnov and our mechanism; , GRI mechanism.

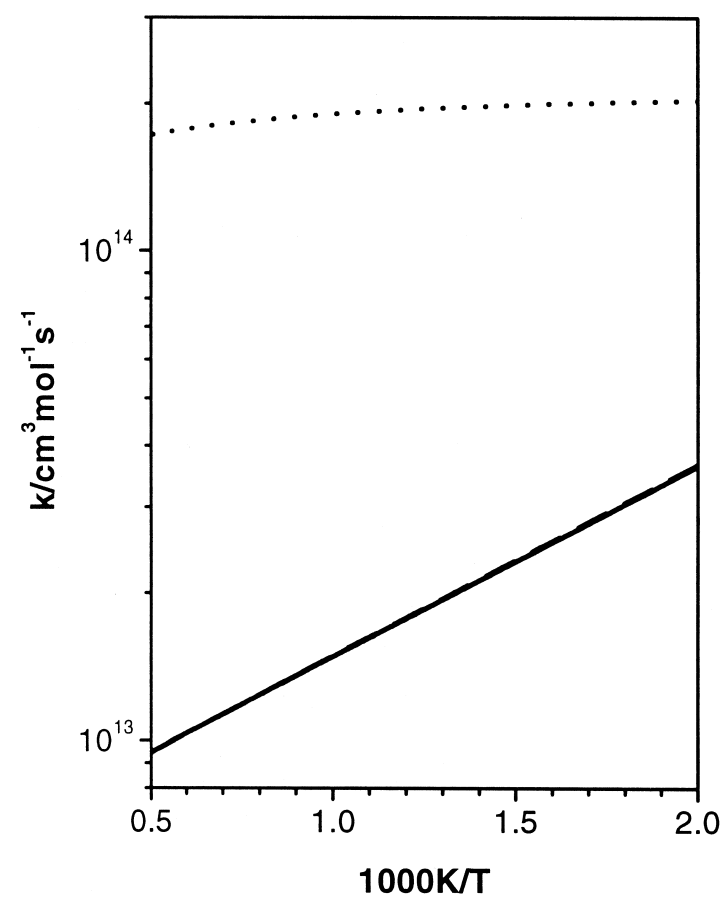

Figure 40 Rate coefficients for reaction (44) between 500 and 2000 K. — Konnov, Chevalier, and our mechanism; ………..... GRI mechanism. 
bon monoxide, methane, ethane, and ethene. Its rate coefficient expressions were based, where possible, on evaluated rate data with minimal alterations for carefully selected reactions. The mechanism has been tested against a variety of experimental data and compared with three alternative reaction mechanisms. It has been shown to perform in a satisfactory manner under most situations. It is deficient in some areas, most noticeably in the simulation of the laminar flame speed of a rich methane/air flame. Analysis of the reaction sensitivity data under these conditions indicates that either the mechanism is lacking a significant reaction or reactions, and/or some of the currently accepted rate data are incorrect.

The GRI approach has significant advantages and drawbacks. The obvious advantage is that the resulting mechanism describes the experimental data somewhat more accurately than other untuned mechanisms. This advantage is retained so long as the conditions of practical application are close to the conditions of one of the experiments used for tuning, and if the corresponding experiment provided accurate data. The drawbacks are associated with the interdependence of the reaction rate parameters, and it is not advisable to substitute new values for the parameters when accurate experimental data become available for some reactions without retuning. Another consequence is that this mechanism may not be suitable as a base module for building combustion mechanisms of other hydrocarbon fuels. If the product channels of some reactions are inappropriate, or one of the fixed parameters is incorrect, or some of the experimental data are incorrect, the whole mechanism can be mistuned.

Another approach, used also for the construction of the Leeds methane oxidation mechanism, is to apply evaluated data and data from direct kinetic measurements whenever possible, with only minimal tuning of few rate coefficients within their experimental uncertainty. This approach does not provide optimized results, but the mechanism obtained can be used for experimental conditions not tested, and the mechanism can be used as a building block for other fuels.

The four mechanisms reproduce the bulk experimental data to a similar level of accuracy. The calculated results follow closely the experimental results, but the agreement is not perfect for any of the mechanisms. These mechanisms were all created in the last few years, from the same pool of experimental results for elementary reactions, and were tested on almost identical sets of bulk experiments. However, somewhat surprisingly, of the 44 most sensitive reactions, 14 are significantly different in one or more of the mechanisms. Thus, several mechanisms of similar quality have been constructed using substantially different rate expressions for important reaction steps. This indicates that the general assumption - that the chemistry of oxidation of simple fuels such as carbon monoxide, methane, and ethane is well characterized at the elementary reaction level - is not correct. More work is required on the experimental and theoretical study of elementary reactions, collecting more reliable bulk experimental data for testing, and performing model calculations with detailed mechanisms to achieve a higher level of quantitative description of the oxidation of simple fuels.

We wish to acknowledge OTKA grant number T025875, SNSF grant number 7UNPJ048687, and EU Copernicus contract number CIPA-CT-93-0163.

\section{BIBLIOGRAPHY}

1. Warnatz, J. Ber Bunsenges Phys Chem 1983, 87, 1008 1022.

2. Warnatz, J. In Reduced Kinetic Mechanisms for Applications in Combustion Systems; Peters, N.; Rogg, B., Eds.; Springer-Verlag: New York, 1993: p. 10-16.

3. Miller, J. A.; Bowman, C. T. Prog Energy Combust Sci 1989, 15, 287-338.

4. Barbe, P.; Battin-Leclerc, F.; Côme, G. M. J Chim Phys 1995, 92, 1666-1692.

5. Frenklach, M. Combustion and Flame 1984, 58, 69-72.

6. Frenklach, M.; Wang, H.; Rabinowitz, M. J. Prog Energy Combust Sci 1992, 18, 47-73.

7. Frenklach, M.; Wang, H.; Bowman, C. T.; Hanson, R. K.; Smith, G. P.; Golden, D. M.; Gardiner, W. C.; Lissianski, V. Twenty-fifth Symposium (International) on Combustion; The Combustion Institute: Pittsburgh, PA, 1992, Poster WIP-3-26.

8. Bowman, C. T.; Hanson, R. K.; Davidson, D. F.; Gardiner, W. C., Jr.; Lissianski, V.; Frenklach, M.; Goldenberg, M.; Smith, G. P.; Golden, D. M.; Serauskas, R. V. Twenty-sixth Symposium (International) on Combustion; The Combustion Institute: Pittsburgh, PA, 1994, Poster WIP-4-47.

9. Smith, G. P.; Golden, D. M.; Frenklach, M.; Moriarty, N. W.; Eiteneer, B.; Goldenberg, M.; Bowman, C. T.; Hanson, R. K.; Song, S.; Gardiner, W. C., Jr.; Lissianski, V. V.; Qin, Z. http://www.me.berkeley.edu/gri_mech.

10. Kee, R. J.; Rupley, F. M.; Miller, J. A. Chemkin-II: A Fortran Chemical Kinetics Package for the Analysis of Gas Phase Chemical Kinetics; Sandia National Laboratories Report No. SAND89-8009B, 1991.

11. Konnov, A. A. http://homepages.vub.ac.be/ akonnov.

12. Chevalier, C. Dissertation Universität Stuttgart, 1993.

13. Pilling, M. J.; Turányi, T.; Hughes, K. J. http:// www.chem.leeds.ac.uk/Combustion/Combustion.html. 
14. Baulch, D. L.; Cobos, C. J.; Cox, R. A.; Esser, C.; Frank, P.; Just, Th.; Kerr, J. A.; Pilling, M. J.; Troe, J.; Walker, R. W.; Warnatz, J. J Phys Chem Ref Data 1992, 21, 411-734.

15. Baulch, D. L.; Cobos, C. J.; Cox, R. A.; Frank, P.; Hayman, G.; Just, Th.; Kerr, J. A.; Murrels, T.; Pilling, M. J.; Troe, J.; Walker, R. W.; Warnatz, J. Combustion and Flame 1994, 98, 59-79.

16. Lutz, A. E.; Kee, R. J.; Miller, J. A. Senkin: A Fortran Program for Predicting Homogeneous Gas Phase Chemical Kinetics with Sensitivity Analysis; Sandia National Laboratories Report No. SAND87-8248, 1988.

17. Kee, R. J.; Grcar, J. F.; Smooke, M. D.; Miller, J. A. A Fortran Program for Modeling Steady Laminar One-Dimensional Premixed Flames; Sandia National Laboratories Report No. SAND85-8240, 1985.

18. Glarborg, P.; Miller, J. A.; Kee, R. J. Combustion and Flame 1986, 65, 177-202.

19. Mallard, W. G.; Westley, F.; Herron, J. T.; Hampson, R. F.; Fizzell, D. H. NIST Chemical Kinetics Database, Ver 6.0, NIST Standard Reference Data, Gaithersburg, MD, 1994

20. Baulch, D. L. Reaction Kinetics Database, School of Chemistry, The University of Leeds.

21. Tsang, W.; Hampson, R. F. J Phys Chem Ref Data 1986, 15,1087

22. Warnatz, J. In Combustion Chemistry; Gardiner, W. C., Jr., Ed.; Springer-Verlag: New York, 1984; p. 197.

23. Dóbé, S.; Bérces, T.; Temps, F.; Wagner, H. Gg.; Ziemer, H. J Phys Chem 1994, 98, 9792-9800.

24. Collin, G. J.; Deslauriers, H.; De Mare, G. R.; Poirier, R. A. J Phys Chem 1990, 94, 134-141.

25. Duran, R. P.; Amorebieta, V. T.; Colussi, A. J. J Phys Chem 1988, 92, 636-640.

26. Grotheer, H. H.; Kelm, S.; Driver, H. S. T.; Hutcheon, R. J.; Lockett, R. J.; Lockett, R. D.; Robertson, G. N. Ber Bunsenges Phys Chem 1992, 96, 1360-1376.

27. Egolfopoulos, F. N.; Law, C. K. Twenty-third Symposium (International) on Combustion; The Combustion Institute: Pittsburgh, PA, 1990; pp. 333-340.

28. Vagelopoulos, C. M.; Egolfopoulos, F. N.; Law, C. K. Twenty-fifth Symposium (International) on Combustion; The Combustion Institute: Pittsburgh, PA, 1994, pp. $1341-1347$.

29. Dowdy, D. R.; Smith, D. B.; Taylor, S. C.; Williams, A. Twenty-third Symposium (International) on Combustion; The Combustion Institute: Pittsburgh, PA, 1990; pp. 325-332.

30. Aung, K. T.; Hassan, M. I.; Faeth, G. M. Combustion and Flame 1997, 109, 1-24.

31. Asaba, T.; Gardiner, W. C., Jr.; Stubbeman, R. F. Tenth Symposium (International) on Combustion; The Combustion Institute: Pittsburgh, PA, 1965; pp. 295-302.

32. McLean, I. C.; Smith, D. B.; Taylor, S. C. Twenty-fifth Symposium (International) on Combustion; The Combustion Institute: Pittsburgh, PA, 1994; pp. 749-757.

33. Baulch, D. L.; Drysdale, D. D.; Duxbury, J.; Grant, S. Evaluated Kinetic Data for High Temperature Reac- tions, Vol. 3: Homogeneous Gas Phase Reactions in the $\mathrm{O}_{2}-\mathrm{O}_{3}$ System, the $\mathrm{CO}-\mathrm{CO}_{2}-\mathrm{H}_{2}$ System, and of Sulphur-containing Species; Butterworths: London, 1976.

34. Gardiner, W. C., Jr.; McFarland, M.; Morinaga, K.; Takeyama, T.; Walker, B. F. J Phys Chem 1971, 75, 1504-1509.

35. Taylor, S. C. Ph.D. Thesis, University of Leeds, 1991.

36. Brouard, M.; Macpherson, M. T.; Pilling, M. J. J Phys Chem 1989, 93, 4047-4059.

37. Cobos, C. J.; Troe, J. Z Phys Chem NF 1990, 167, 129 149.

38. Cheng, J.-T.; Yeh, C-T. J Phys Chem 1977, 81, $1982-$ 1984.

39. Troe, J. Z Phys Chem NF 1989, 161, 209-232.

40. Tsuboi, T.; Wagner, H. Gg. Fifteenth Symposium (International) on Combustion; The Combustion Institute: Pittsburgh, PA, 1974; pp. 883-890.

41. Seery, D. J.; Bowman, C. T. Combustion and Flame 1970, 14, 37-47.

42. Hus, D. S. Y.; Shaub, W. M.; Creamer, T.; Gutman, D.; Lin, M. C. Ber Bunsenges Phys Chem 1983, 87, 909919.

43. Saito, K.; Ito, R.; Kakumoto, K.; Imamura, A. J Phys Chem 1986, 90, 1422-1427.

44. Brabbs, T. A.; Brokaw, R. S.Fifteenth Symposium (International) on Combustion; The Combustion Institute: Pittsburgh, PA, 1974; pp. 893-901.

45. Bhaskaran, K. A.; Frank, P.; Just, Th. High Temperature Methyl Radical Reactions with Atomic and Molecular Oxygen; Proceedings of the Twelfth Symposium On Shock Tubes and Waves; The Magnes Press: Jerusalem 1979; p 503.

46. Egolfopoulos, F. N.; Zhu, D. L.; Law, C. K. Twentythird Symposium (International) on Combustion; The Combustion Institute: Pittsburgh, PA, 1990; pp. 471478.

47. Takahashi, K.; Inomata, T.; Moriwaki, T.; Okazaki, S. Bull Chem Soc Jpn 1989, 62, 2138-2145.

48. Burcat, A.; Crossley, R. W.; Scheller, K. Combustion and Flame 1972, 18, 115-123.

49. Slagle, I. R.; Park, J-Y.; Heaven, M. C.; Gutman, D. J. Am Chem Soc 1984, 106, 4356-4361.

50. Baldwin, R.; Walker, R. W. Eighteenth Symposium (International) on Combustion; The Combustion Institute: Pittsburgh, PA, 1981; pp. 819-829.

51. Bernstein, J. S.; Fein, A.; Choi, J. B.; Cool, T. A.; Sausa, R. C.; Howard, S. L.; Locke, R. J.; Miziolek, A. W. Combustion and Flame 1993, 92, 85-105.

52. Stewart, P. H.; Smith, G. P.; Golden, D. M. Int J Chem Kinet 1989, 21, 923-945.

53. Stewart, P. H.; Larson, C. W.; Golden, D. M. Combustion and Flame 1989, 75, 25-31.

54. Yu, C.-L.; Wang, C.; Frenklach, M. J Phys Chem 1995, 99, 14377-14387.

55. Kim, T. J.; Yetter, R. A.; Dryer, F. L. Twenty-fifth Symposium (International) on Combustion; The Combustion Institute: Pittsburgh, PA, 1994; pp. 759-766.

56. Mulenko, S. A. Rev Roum Phys 1987, 32, 173. 